\title{
O produtor e o processo de produção dos filmes de longa metragem brasileiros
}

Dissertação apresentada ao programa de Pós-Graduação em Ciências da Comunicação, Área de Concentração Comunicação e Estética do Audiovisual, da Escola de Comunicações e Artes da Universidade de São Paulo, como exigência parcial para obtenção do título de Mestre em Ciências da Comunicação, sob orientação do Profo. Dr. Eduardo Simões dos Santos Mendes. 


\section{O produtor e o processo de produção dos filmes de longa metragem brasileiros}

Dissertação apresentada ao programa de Pós-Graduação em Ciências da Comunicação, Área de Concentração Comunicação e Estética do Audiovisual, da Escola de Comunicações e Artes da Universidade de São Paulo, como exigência parcial para obtenção do título de Mestre em Ciências da Comunicação, sob orientação do Profo. Dr. Eduardo Simões dos Santos Mendes. 


\section{O produtor e o processo de produção dos filmes de longa metragem brasileiros}

Dissertação apresentada ao programa de Pós-Graduação em Ciências da Comunicação, Área de Concentração Comunicação e Estética do Audiovisual, da Escola de Comunicações e Artes da Universidade de São Paulo, como exigência parcial para obtenção do título de Mestre em Ciências da Comunicação, sob orientação do Profo. Dr. Eduardo Simões dos Santos Mendes.

Presidente:

$1^{\circ}$ Membro:

$2^{\circ}$ Membro: 


\section{RESUMO}

objeto:

O objeto de estudo é a produção dos filmes de longa metragem de ficção brasileiros desde a data de realização das primeiras filmagens feitas no Brasil até os dias atuais.

metas:

O objetivo deste trabalho é definir um processo de produção e apresentar o papel do produtor nesse processo dentro dos modelos utilizados pela indústria cinematográfica para, a partir disso, montar um painel da história do Cinema Brasileiro que mostre sua evolução e seus desafios atuais.

resultados:

Diferente de outros países que utilizam o cinema como forma de preservação de sua história e cultura, o Brasil está atrelado a uma produção sazonal, sem um projeto político que garanta sua mais livre forma de expressão. As conclusões indicam que enquanto esse projeto não for construído, não teremos um cinema que nos represente e o produtor desempenha um papel bastante relevante.

palavras chaves

cinema brasileiro, produção, produtor, realização, indústria cinematográfica 


\section{Abstract}

subject:

Throughout the history of the Brazilian Cinematography and its detailed analysis, this dissertation debates the producer's role and his/her influence into the movie's producing process. In the same direction, it is also analyzed the Brazilian Movies Industry's current perspectives and challenges.

goals:

The part played by the producer in the history of Brazilian cinematography and the producer's influence on film making are the focus of this dissertation; within this context, current trends in and challenges faced by the national film making industry will be explored.

results:

Without a political project to consider the preservation of its culture and history, brazilian industry movies cannot be consummate. 


\section{Sumário:}

\section{página}

Introdução

Capitulo 1: A produção e o produtor ............................................... 13

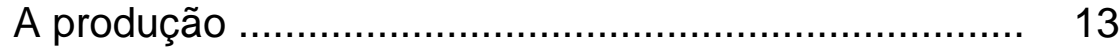

O produtor ....................................................... 16

As funções necessárias a uma produção ..................... 23

As etapas de produção ........................................... 24

Os modelos de equipe de produção ........................... 29

Capitulo 2: O cinema brasileiro - Panorama histórico ..................... 32

Ciclo da Belle Époque ..................................... 32

Ciclos regionais ............................................ 36

Ciclo das chanchadas ..................................... 42

Ciclo da Vera Cruz ............................................. 46

Ciclo do cinema educativo .................................... 49

Ciclo do Cinema Novo ............................................ 50

Ciclo da Embrafilme .............................................. 55

Ciclo do cinema marginal ....................................... 61

Ciclo das pornochanchadas ............................... 62

Ciclo da retomada .............................................. 65

Capitulo 3: O cinema brasileiro atual ..................................... 73

Desafios para o produtor brasileiro de longas metragens

Conclusões

Referências Bibliográficas

Anexos

Anexo I - $1^{\circ}$ Lei de Obrigatoriedade Brasileira ............. 85

Anexo II - Criação do INC .................................... 88

Anexo III - Embrafilme e Concine ........................... 97

Anexo IV - Lei do Audiovisual ................................ 104

Anexo V - Lei Rouanet ...................................... 106 


\section{Introdução}

"A produção é a arte de prever o imprevisível e sempre se dar mal."1

Esse foi o jeito que Federico Fellini encontrou para falar do trabalho da equipe de produção em seus filmes.

Assim como a atônita equipe de TV japonesa, que aparece no filme correndo atrás de Fellini, querendo entender qual é o processo que faz com que seus filmes tenham determinadas características que o transformam em "um filme de Fellini", gostaria de propor uma primeira reflexão: quais são as características que dão ao filme um caráter que o classifica com "um filme de fulano de tal", ou seja "o filme de um artista", ou um "filme de um determinado autor".

Observando melhor, nem todos os filmes são classificados dessa forma. Alguns filmes são conhecidos como "filmes hollywoodianos"; que determina o lugar onde foram feitos e não por quem foi feito (e em muitas vezes o autor é completamente ignorado). Outros, são classificados como "filmes do cinema novo", que não determina nem o local nem o autor, mas filmes que pertenceram a uma época e / ou a um movimento artístico, por exemplo, "filmes da nouvelle vague".

Várias perguntas se sucedem: o que define a autoria de um filme, quem é o autor, porque os filmes são classificados de formas distintas? Por que, às vezes, identificamos filmes por seus diretores e , em outras vezes, pelos locais onde foram feitos?

Além disso, acredito que se possa elaborar uma pergunta capaz de responder essas questões: por que uma equipe de jornalistas que, ao querer entender o processo de realização de um filme, é apresentada a um grupo de pessoas aparentemente atrapalhadas, chamadas genericamente de "produção"? O que faz a produção de um filme? O que a produção tem a ver com a autoria do filme? O que essa equipe ou esse processo tem a ver com a atribuição de características a determinados filmes?

Essas são perguntas que têm grande amplitude porque valem para filmes produzidos em todo o mundo. E o processo de feitura de filmes depende de fatores sociais, econômicos e políticos que, às vezes, são exclusivos a um determinado país. Por isso, fazer um recorte do que acontece no Brasil pode ser um caminho para se entender como se dá a realização dos filmes de longa metragem brasileiros. É claro que não tenho vontade de fazer qualquer analogia do processo de produção brasileira, igualando nossa realidade com um universo maior. Mas, entender o processo de realização de filmes que compõem o cinema brasileiro, através de seu modo de produção ajuda a compor um painel sobre a construção de uma cinematografia.

Nesse caso, repito as mesmas perguntas focadas no cinema brasileiro: o que faz um filme ser identificado por um autor como Glauber Rocha, ou a uma época como "os filmes da Belle Époque", ou ainda a um determinado gênero como "chanchadas", ou ainda a um lugar, como "filmes da Vera Cruz"?

\footnotetext{
${ }^{1}$ Federico Fellini, em cena do filme "Entrevista" (Intervista, 1987), ao apontar seu produtor para apresentá-lo a uma equipe de televisão japonesa. Roteiro e direção de Federico Fellini.
} 
A proposta desta dissertação é entender o processo de realização de um longa metragem nacional, ou seja, a sua produção. E entender como a produção interfere no resultado de um filme, a ponto de lhe conferir sentidos que possibilitam um tipo de classificação, é uma forma de enxergar como o Brasil se manifesta através de seu cinema, como constrói sua cultura e sua sociedade.

Ao agrupar filmes por gêneros, por épocas, por movimentos que aconteceram em um período histórico, ou pela associação às empresas que os produziram, percebese que elo que os une vai além de questões estéticas ou artísticas. A ligação também pode se dar por uma maneira de como ele foi realizado em um certo período de tempo. Destrinchar a maneira de como se organiza um trabalho que vai resultar em um filme é falar de seu processo de produção.

A história do cinema brasileiro mostra movimentos cíclicos que começaram por conta de algum estímulo (uma lei, por exemplo); tiveram um momento de aquecimento e auge, e terminaram por problemas que não conseguiram ser solucionados num certo período de tempo.

A maioria dos pesquisadores apresenta os ciclos em ordem cronológica. Outros, apontam como elemento comum questões estéticas, artísticas ou políticas. Além das questões estéticas, artistas, ideológicas ou políticas Ao estudar esses ciclos, identifico que eles também apresentam uma maneira de realização parecida.

Por isso, quero propor uma reflexão sobre a produção de filmes ao longo da história, através dos ciclos apontados pela maioria dos pesquisadores. Quero fazer uma análise da produção de filmes através da atuação de seus produtores.

Para tal, começo por definir o sentido do termo "produção" e o papel que as pessoas responsáveis pela produção, os produtores, desempenham.

Essas são questões que geram algumas divergências e um pouco de mistificação. É muito comum, no mercado de trabalho cinematográfico atual, ver o produtor representado de duas formas: ou ele é o dono do filme, detentor de um poder supremo, que manda e desmanda, e está acima do bem e do mal; ou sendo a mãode-obra mais desqualificada dentro do processo de produção, que faz de tudo um pouco e sempre faz tudo muito mal.

A mistificação também acontece quando se comenta sobre o processo de realização do filme. É recorrente se imputar a um filme fantástico a genialidade do diretor. Ouvimos: "trata-se de um artista fenomenal!". E quando o filme é um lixo, a culpa cairá nas costas de sua produção (da equipe de produção ou da maneira como foi realizado).

Dessa forma, desconsidera-se a principal característica para o sucesso ou o fracasso de uma obra cinematográfica, que é um conjunto de ações realizadas por profissionais com especificidades diferentes. Um filme, especialmente, é a somatória de uma série de fatores sincronizados onde cada pessoa que esteja envolvida em sua realização, desempenha um importante papel. É, fundamentalmente, um trabalho de equipe onde a função do produtor, assim como da equipe de produção, é fundamental. 
Sidney Lumet, em seu livro "Making movies", comenta as etapas de uma produção de um filme e o trabalho de cada um dos técnicos envolvidos durante as fases da realização. Cada capítulo é dedicado a uma função. E, no final dos capítulos onde ele comenta o trabalho da direção de arte, da direção de fotografia e da direção, lemos uma frase como esta: "we're all making the same movie". (Lumet, 1995, p. 58 $-27-93-104-136-146)^{2}$

O que Lumet quer dizer é que: fazer um filme é um trabalho de equipe onde todos desempenham funções que culminam em um produto único. A chance do filme ser bem-sucedido (ou econômica ou artisticamente) é muito maior se toda a equipe estiver concentrada em um único filme, naquele que está sendo produzido e não naquele que está na cabeça de cada um dos envolvidos. A brincadeira do autor na frase: "estamos todos fazendo o mesmo filme" se justifica quando nem sempre uma equipe demonstra coesão ou entendimento de seu papel na construção daquela específica obra cinematográfica.

Como mostrarei, o produtor é um dos responsáveis por montar uma equipe capaz de manter por manter essa coesão.

Mas, ao longo da história, o conceito percebe-se que o produtor interfere de maneiras diferentes. Proponho uma análise de sua interferência.

Essa será a abordagem do primeiro capítulo.

O cinema brasileiro apresenta uma história cronológica de sucessivos ciclos, desde o dia que foi decretado seu nascimento até os dias atuais.

Jean-Claude Bernardet inicia seu livro "Historiografia clássica do cinema brasileiro" com a seguinte frase: "O cinema brasileiro nasceu a 19 de junho de 1898." (Bernardet, 2004, p. 17). Refere-se à primeira filmagem feita no Brasil e apresenta a certidão de nascimento dada pela maioria dos historiadores, observando que alguns pesquisadores levantaram dados de possíveis filmagens anteriores, sem, contudo, apresentarem provas colocando essa data em cheque. Paulo Emílio Salles Gomes ${ }^{3}$ foi categórico. Baseado em pesquisa realizada por Vicente de Paula Araújo ${ }^{4}$, inédita até aquele momento, confirmou sem ressalvas a origem do nosso cinema.

Há um consenso entre os pesquisadores que o autor dessas primeiras imagens, Alfredo Segreto, trabalhava para seu irmão, Paschoal Segreto. Este, por sua vez, possuía uma próspera empresa para a apresentação de espetáculos de diversão,

\footnotetext{
${ }^{2}$ A frase, como citada neste parágrafo aparece apenas nas páginas 58 e 136. As outras páginas trazem pequenas variações mas possuem o mesmo sentido.

3 GOMES, Paulo Emílio Salles, Cinema: trajetória no subdesenvolvimento. São Paulo: Paz e Terra, $2^{\mathrm{a}}$ edição, 2001 (Coleção Leitura).

${ }^{4}$ Tanto Bernardet como Salles Gomes referem-se à pesquisa de Vicente de Paulo Araújo publicada somente em 1976. A primeira edição do ensaio de Paulo Emílio é anterior a essa data. A maioria dos historiadores se apóia nas pesquisas que Araújo realizou abordando os primórdios do cinema brasileiro.
} 
como teatro de variedades, café-concerto e exibição de "vistas animadas" oriundas, principalmente, da França ${ }^{5}$.

Sendo empresários do ramo do entretenimento, os Segreto faziam projeções de pequenos filmetes estrangeiros desde julho de 1896, porém eram espetáculos esporádicos e concentrados no Rio de Janeiro. Um dos possíveis motivos das seções intermitentes foi creditado à escassez de energia elétrica. Existem análises que ampliam a questão e comentam a falta de projeto político para a implantação de um parque industrial no país, até então essencialmente rural, e somente a partir de 1907, com a entrada em operação da primeira grande usina hidroelétrica, o cinema brasileiro pode florescer.

Mesmo incipiente, a projeção de filmes curtos sem enredo mostrava ser um negócio bastante rentável e, por isso, o empresário incumbiu ao irmão a missão de trazer da França para o Brasil uma câmera de filmar junto com o material sensível. Ao entrar no país pela Baía da Guanabara, ainda em território francês, pois estava a bordo do paquete Brésil, Alfredo filmou cenas de sua entrada no porto do Rio de Janeiro, ou mais precisamente "vistas animadas" - como eram chamadas nesta época - com uma câmera recém-comprada. E assim começou a história do cinema brasileiro.

Este é um nascimento “... que não deixa de ser estranho: um italiano (radicado no Brasil), com equipamento e material sensíveis europeus, filma em território francês (o paquete Brésil), um filme brasileiro". (Bernardet, 2004, p. 18)

Bernardet frisa que a data foi escolhida por motivos ideológicos, uma vez que na maioria dos outros países, a origem do cinema se dá na primeira exibição. Nós, brasileiros, ao contrário, escolhemos como marco inicial o dia de nossa primeira filmagem. Bernardet faz um profundo questionamento sobre sua real existência, uma vez que não existem documentos que provam que Segreto já dominasse técnicas de exposição do negativo à luz tropical, revelação e operação do equipamento recémcomprado. Além disso, o autor afirma que não há registro de projeção das cenas filmadas por Segreto. Há apenas registros jornalísticos dando conta que a sala de espetáculos da família se incendiou pouco depois da filmagem e que todo o acervo contido ali fora destruído. (Bernardet, 2004, p. 32-33).

Não deixa de ser curioso e significativo o fato do cinema brasileiro começar justamente com a iniciativa de empresários, proprietários de salas exibidoras de filmes estrangeiros, que, ao perceberem a rentabilidade trazida pela novidade da imagem em movimento, trataram de montar suas próprias companhias produtoras de filmes. Mas, mais curioso ainda, é o fato de que, nas cinematografias de outros países, as datas escolhidas para representarem seu nascimento são dias que aconteceram as primeiras exibições públicas de cenas filmadas em seus países. No Brasil, escolhemos o dia de nossa suposta primeira filmagem.

Questões sobre o domínio de uma tecnologia que importamos desde então e sobre a exibição dos filmes realizados no Brasil têm sido o foco da angústia e anseios de

\footnotetext{
${ }^{5} \mathrm{O}$ consenso a que me refiro foi encontrado na bibliografia consultada e indicada tanto nas notas de rodapé como nas referências bibliográficas. Independente disso, o fato é que a data é comemorada como o nascimento do Cinema Brasileiro.
} 
realizadores e produtores. $E$ até hoje interferem na produção da indústria cinematográfica nacional.

Ao longo de seus cento e poucos anos, o cinema brasileiro vive as mesmas "estranhezas" (angústias ou problemas) já evidenciadas em seu nascimento: a dependência de tecnologia estrangeira e a falta de pontos de exibição. São problemas constantes e, quando resolvidos pontualmente, iniciam uma etapa que pode se encerrar a qualquer momento, como um movimento em círculos, que têm ponto inicial coincidente com o ponto final.

Permeando esses dois problemas, está a produção. Para que um filme exista, sua produção necessita de materiais e equipamentos importados e de mercado.

O estudo da história dos ciclos do cinema brasileiro vai mostrar que essas questões nunca foram equacionadas de forma a deixarem de ser problemas. Através de alguma medida paliativa, um deles foi temporariamente sanado para determinar o início de um ciclo.

O segundo capítulo desta dissertação vai se preocupar com a produção de filmes durante os sucessivos ciclos. Pela ótica da produção, a análise proposta se preocupará com as formas de financiamento de um projeto, de como ele foi realizado e como ele chegou ao seu público.

Vou adotar as mesmas divisões cíclicas que a maioria dos autores utiliza, considerando a periodização estabelecida por Paulo Emílio Salles Gomes (de 1896 a 1966) e de Carlos Roberto de Souza (dos primórdios até 1998).

No intervalo compreendido entre os anos de 1960 a 1990, utilizarei referências propostas por Ismail Xavier e José Mário Ortiz Ramos. Para os filmes produzidos no país a partir de 1992, o apoio teórico se dará nas observações dos críticos contemporâneos que publicaram, até agora, os mais significativos retratos do período como Lúcia Nagib e Luiz Zanin Oricchio, além do levantamento de dados realizado por Paulo Sérgio Almeida e Pedro Butcher para o BNDES ${ }^{6}$. As informações da nossa produção mais recente vêm de fontes como a ANCINE $^{7}$, MPA-AL ${ }^{8}, A B R A P L E X^{9}$, Filme $B^{10}$ e de um estudo elaborado pelo $\mathrm{IPT}^{11}$ e que ainda

\footnotetext{
${ }^{6}$ BNDES - Banco Nacional de Desenvolvimento Econômico e Social - agente financeiro estatal que é, atualmente, uma das principais fontes financiadoras de recursos para a produção cinematográfica.

${ }^{7}$ ANCINE - Agência Nacional do Cinema

${ }^{8}$ MPA-AL - Motion Picture Association - Latin American Regional Office

9 ABRAPLEX - Associação Brasileira das Empresas Exibidoras Cinematográficas Operadoras de Multiplex.

${ }^{10}$ Periódico, especializado no mercado cinematográfico brasileiro, que traz indicadores econômicos e estatísticos sobre a exibição de filmes no Brasil.

${ }^{11}$ IPT - Instituto de Pesquisas Tecnológicas do Estado de São Paulo da Secretaria da Ciência, Tecnologia e Desenvolvimento Econômico do Estado de São Paulo.
} 
não foi publicado ${ }^{12}$.

Mesmo que autores como Jean-Claude Bernardet questionem o sentido de uma periodização, defendendo a idéia que critérios podem propiciar análises restritivas, e mesmo concordando que a proposta de Paulo Emílio priorize a produção cinematográfica carioca, considero que os modelos de produção praticados em determinados períodos são comuns e se caracterizaram como ciclos. E, além disso, eles podem ser analisados a partir de uma linearidade cronológica.

Assim, acredito ser possível fazer um painel bastante pertinente de nossa produção e da exibição de nossos filmes.

Por fim, no terceiro capítulo da dissertação, há a apresentação dos desafios que estão colocados hoje para a indústria cinematográfica brasileira, a partir da constatação que estamos entrando em um momento de esgotamento do modelo praticado hoje.

\footnotetext{
12 O relatório intitulado: "Propostas de políticas públicas para o aumento da competitividade do segmento de cinema paulista", foi finalizado em de agosto de 2005. Ele me foi enviado por e-mail em 23 de agosto de 2006, pela técnica do IPT Solange Machado contendo a seguinte ressalva: "procuramos reunir o máximo de informações possíveis, sem nos importarmos muito com a elegância do texto. Por isso, eu ainda não divulguei amplamente. Até o final do ano vamos produzir um livro baseado no relatório, com dados atualizados. Solange". O foco do trabalho é o cinema paulista, já que ele partiu de uma iniciativa de várias entidades paulistas. Hoje, existe no site da CINEMABRASIL (http://www.cinemabrasil.org.br) um link para download dos gráficos contidos no relatório que abordam o mercado do cinema brasileiro e é um dos capítulos deste trabalho a mim enviado.
} 


\section{capítulo 1: A produção e o produtor}

Quando se fala em produção, alguns conceitos se misturam e provocam algumas confusões. "Produção", "produtor" e "produtora" são termos usados indiscriminadamente para falar de processo de realização, da equipe de profissionais que trabalham durante um processo, da mão-de-obra mais desqualificada que atua no processo, do dono do filme, da empresa responsável pelo processo, entre outras coisas.

Ao relembrar a frase dita por Fellini ${ }^{13}$, ("a produção é a arte de prever o imprevisível e sempre se dar mal") várias perguntas se sobrepõem: sobre quem (ou sobre o quê) ele está falando? Ele aponta para uma pessoa, que aparentemente é quem está comandando um processo. Em volta dessa pessoa, várias outras pessoas também envolvidas no processo, mas fazendo coisas completamente diferentes ${ }^{14}$. Ele fala de uma pessoa que prevê, que faz um planejamento que vai dar em nada. Por outro lado, Fellini poderia estar falando da equipe, aparentemente estressada, envolvida no processo, pois, de fato, quem está se "dando mal" é ela. Fellini está falando da pessoa que comanda, do processo ou da equipe? Se esse processo resultará em um filme, quem ou o quê vai fracassar?

O passo seguinte é destrinchar esses conceitos.

\section{A produção}

Começo buscando uma definição para a palavra "produção" e as funções que cabem a ela dentro da cadeia produtiva de um filme.

De uma maneira genérica, Chris Rodrigues define a produção como sendo "tudo que envolve fazer um filme, incluindo seu planejamento e captação de recursos." (Rodrigues, 2002, p. 68).

A definição de Rodrigues, aliada à fala de Fellini, pode gerar várias interpretações.

Para organizar o fluxo das idéias, resumo os significados que são constantemente atribuídos à palavra "produção" a partir dos dois autores:

$\left.1^{\circ}\right)$ A produção entendida como uma função, desempenhada por pessoas com formação técnica e capazes de realizar determinadas tarefas, algumas bastante específicas.

$\left.2^{\circ}\right)$ A produção entendida como o resultado final, o filme.

$3^{\circ}$ ) A produção entendida como a proprietária do filme. A propriedade pode ser definida como "o direito de titularidade sobre a criação intelectual em atividades, produtos, idéias ou símbolos relacionados a processos industriais ou comerciais"15.

$4^{\circ}$ ) A produção entendida como um processo de transformação de uma determinada matéria-prima até um produto acabado.

\footnotetext{
${ }^{13}$ Ver p. 07 desta dissertação.

${ }^{14}$ Eles estão na Cinecittà, em um set de filmagem e no contra-plano aparecem operador de câmera, cenógrafo, assistentes, entre outros.

15 Dicionário Houaiss da Língua Portuguesa para definição da palavra propriedade http://houaiss.uol.com.br , último acesso: 04/02/2007.
} 
Segundo o Glossário da Produção, publicado em 09/12/2002 pela Secretaria do Desenvolvimento da Produção do Ministério do Desenvolvimento, Indústria e Comércio Exterior - a produção pode ser definida como "um conjunto de atividades (elos) que se articulam progressivamente desde os insumos básicos até o produto final, incluindo bens de capital, bens intermediários, distribuição e comercialização."

Aqui defino a palavra "produção" como um processo de transformação, desde a idéia inicial até o momento que o filme esteja pronto. Resultado final, propriedade e função desempenhada por profissional não se encaixam mais na definição adotada.

Todo processo de transformação passa por diversas etapas. Fazendo um esquema simplificado das etapas ${ }^{16}$ de produção de um filme, temos ao seguinte:

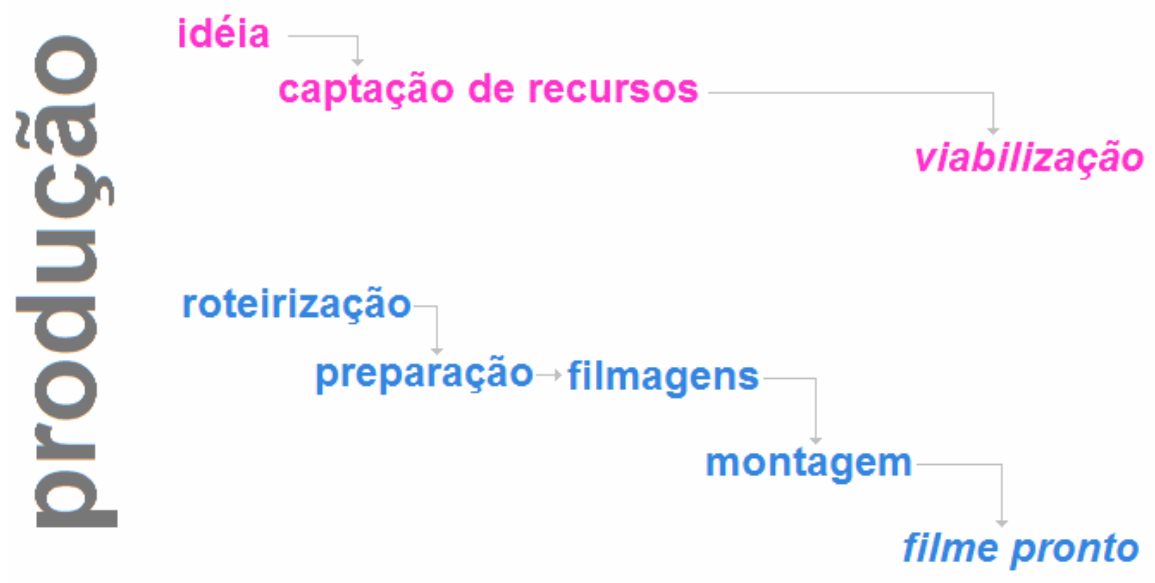

Ou um explicando com mais detalhes: a partir de uma idéia, busca-se uma forma de viabilização através do levantamento de recursos financeiros ou outras formas de apoio (como, por exemplo, empréstimo de materiais, doações, cotização de serviços, etc.), faz-se um planejamento para que haja uma condição mínima de se ter um produto final, executa-se o que foi planejado através das filmagens e da montagem e dá-se o acabamento final. Esta é a descrição de um processo, divido em algumas etapas, concomitantes ou não. Portanto, podemos partir do princípio que a produção cinematográfica é um processo com começo (idéia), meio (viabilização) e fim (filme pronto).

Filmes prontos, conforme a visão da Secretaria do Desenvolvimento da Produção, são feitos para serem vistos (comercializados) por alguém. Aqui começa um outro processo que é a exibição do filme para um público.

Nos primórdios do cinema, usualmente, um grupo de pessoas produzia um filme, reunia outro grupo e projetava-0. Com o passar do tempo, produção e exibição acabaram adquirindo características específicas e se tornaram práticas distintas.

\footnotetext{
${ }^{16}$ As etapas da produção serão retomadas adiante, depois de comentar as funções que os profissionais que atuam no processo desenvolvem.
} 
Surge uma terceira instância: a distribuição, que se encarrega de fazer a ponte entre as etapas de produção e de exibição ${ }^{17}$.

Inicialmente o distribuidor negociava os filmes comprando do produtor e revendendo aos exibidores, copiando um modelo praticado pela indústria de uma forma geral. No Brasil, várias importadoras se estabeleceram negociando a importação dos filmes norte-americanos e revendendo-os aos exibidores nacionais. Mas, ainda na primeira metade do século passado, os Estados Unidos impuseram um novo modelo de negócios específico para a distribuição de filmes: os distribuidores passaram a alugar as cópias de filmes e esse sistema permanece até hoje.

Com o passar do tempo, essas três etapas se diferenciam pelo modelo de negócios que cada uma dessas áreas pratica. Mas, são os três elementos que sustentam a atividade cinematográfica desde $1908^{18}$.

O tripé de sustentação da indústria cinematográfica normalmente é representado da seguinte forma:

\section{distribuição}

produção

exibição

É claro que eu relatei de forma esquemática e genérica a construção do tripé produção / distribuição / exibição. As experiências para constituição ou implantação de uma indústria cinematográfica aconteceram de forma diferenciada nos países que tiveram esse projeto como perspectiva. E o foco agora são as questões que envolvem exclusivamente a produção de filmes de longa metragem no Brasil.

\footnotetext{
${ }^{17}$ Isso aconteceu com a indústria de uma forma geral quando a massificação da venda dos produtos industrializados mudou completamente a organização econômica mundial no período histórico chamado de "revolução industrial". O cinema acompanhou essa transformação, mas desenvolveu um modelo de negócios específico. Porém, o tripé de sustentação produção / distribuição / exibição não é uma exclusividade da indústria cinematográfica, ele é praticado pela indústria e as diferenciações estão na nomenclatura, por exemplo, o que chamamos de exibição, o setor industrial nomeia de pontos de venda. Vale ressaltar que o conceito é o mesmo: é local onde se dá a chegada do produto industrializado ao consumidor final.

${ }^{18}$ A Motion Pictures Patents Company (1908-1912), foi a primeira companhia que se tem notícias fundada com o objetivo específico de vender os filmes produzidos em Hollywood para os nickelodeons nova-iorquinos. Thomas Edson era um dos sócios da MPPC. Enriqueceram mas não suportaram as acusações de "trust" e subornos. Quando fecharam, os próprios produtores abriram suas companhias distribuidoras. Com o passar do tempo, os distribuidores se tornaram os principais agentes da indústria. No caso do cinema brasileiro, abordarei a sua ação durante a explanação da constituição de nossa indústria.
} 


\section{O produtor}

Trabalho na área da produção cinematográfica desde 1984. Comecei naturalmente como assistente de produção até chegar à produção executiva.

Durante minha graduação, fui a única aluna da classe que fez a opção voluntária por esta área. Logo na minha primeira assistência, descobri o motivo de tamanho desinteresse. Naquela época, o "produtor" era uma das funções de menor qualificação dentro de um organograma de equipe.

Ele era uma espécie de coringa que cobria qualquer área como varrer chão, pintar paredes, servir café, achar e contratar atores globais a título de participação em um projeto artístico, descolar locações gratuitas, negociar aluguel (ou empréstimo) de câmeras e outros equipamentos, montar maquetes, entre outras tarefas mais ou menos bizarras, mas que, basicamente, se pudéssemos resumir em uma frase, o produtor seria uma espécie de "realizador de desejos".

Percebi rapidamente que, até em produções mais sofisticadas, o quadro não se alterava muito e a chamada equipe de produção mantinha este mesmo perfil e desempenhava estas mesmas funções. A diferença se dava na quantidade de aportes financeiros. Mas aí os desejos acompanhavam essa proporcionalidade.

Percebi que pessoas que queriam fazer cinema sem ter cursado uma faculdade, começavam como assistentes de produção para depois almejarem a cargos "mais nobres" como diretores e diretores de fotografia. Vi, também, que havia uma expectativa em relação a um bom produtor: ele deveria ser suficientemente astucioso para obter sempre as melhores vantagens, além de ter uma agenda de telefones recheada de contatos "vips" para arranjar qualquer coisa a qualquer hora por um custo ínfimo e ser uma espécie de "quebra-galho" para resolver qualquer tipo de situação ou imprevistos.

Certa vez, durante uma das minhas primeiras produções, ouvi do diretor de fotografia um conselho para que eu não seguisse na área da produção. Ele afirmava categoricamente que minhas produções tenderiam ao fracasso, pois eu não tinha 0 perfil esperado para aquela produção. De fato, ele tinha razão. Nossa concepção e expectativa da função de um produtor estavam colocadas em posições diametralmente opostas.

O depoimento do produtor David L. Wolper confirma minhas impressões:

"Sou um produtor. Faço o que for preciso para transformar uma idéia no produto final. Isso significa que já tive de ser vendedor, diretor, editor de filme, diretor de elenco, consultor criativo. Já cheguei até a dirigir um ônibus." (Kellison, 2006, p. 5).

Um outro "bom mito" construído ao longo dos anos é:

"Diz-se convencionalmente que o cinema é o reino do diretor, que o teatro é o reino do ator e a TV é o reino do produtor". (Kellison, 2006, p. 5).

Fellinis, diretores de fotografia e mitos só me estimularam a querer ter mais clareza sobre o papel do produtor. 
Fui investigar com os profissionais da área e as respostas não me convenceram. Reafirmavam a expectativa da astúcia e da "cavação"19", que, para mim, só reforçava uma idéia amadora do processo de produção cinematográfico. Ou então me apresentavam modelos já copiados de outros lugares sem qualquer preocupação se eles se adequavam à situação específica do filme que eu estava produzindo. Diziam: "Fulano usou esta tabela para fazer a análise técnica do roteiro. Faça igual". Ou ainda: "Não tente inventar a roda. Use este modelo de orçamento, assim você faz como todo mundo e não erra." 20

Mas, um fato chamou minha atenção desde sempre e ele independe do modelo de produção adotado. As produções que fiz tinham um padrão determinado pelas decisões que tomei, seja sozinha ou em conjunto com outros membros da equipe. $\mathrm{E}$ que isso estava refletido na tela do cinema compondo um resultado.

Ao participar da equipe de produção do filme "Um Céu de Estrelas"21, como responsável por seu controle orçamentário, pude elaborar o significado da função de um produtor. Eu pude vivenciar na prática o antes que era intuitivo.

O ano de 1994 marca o início do ciclo da retomada ${ }^{22}$.

Este filme foi o primeiro longa brasileiro a ser filmado com a tecnologia Aaton Code, em S-16 MM, edição em mídia digital e posterior ampliação (blow-up) ${ }^{23}$ para 35 MM. Essa era uma nova forma de realização. As câmeras S-16 da Aaton estavam começando a ser comercializadas e seus revendedores aceitaram uma coprodução.

O investimento girou em torno de trezentos e trinta mil dólares, captados da seguinte forma ${ }^{24}$ :

- Prêmio BANESPA de Incentivo à Produção Cinematográfica (no valor de US\$ 100,000.00),

- Apoio do BNDES, através de um programa de empréstimos a juros subsidiados que tinha como objetivo o fomento à produção industrial (no valor de US\$ 150,000.00),

\footnotetext{
${ }^{19}$ Este termo está sendo usado aqui pela primeira vez com um sentido do produtor ser um descolador, uma pessoa bem sucedida em conseguir favores, empréstimos, etc. O cinema de cavação brasileiro existe desde a década de 1910 e vou falar dele ao abordar a sua história.

${ }^{20}$ Quando eu entrei para o mercado de trabalho, o ciclo da Embrafilme (ver p. 55) começava seu declínio. A partir daí, o cinema brasileiro enfrentaria sua pior crise de produção, que foi parcialmente sanada dez anos depois, já no ciclo da retomada (ver p. 65). Todas as questões que envolveram a função do produtor nessa época estão intimamente ligadas com o modelo de produção praticado durante a era Embrafilme.

${ }^{21}$ Filme produzido pela CASA DE PRODUÇÃO / RENATO BULCÃO e TATA AMARAL, com direção de Tata Amaral. Distribuição: Riofilme. Ano: 1994. Cor. 35MM.

${ }^{22}$ Ver p. 55.

${ }^{23}$ O BLOW UP (ampliação de negativo de Super $16 \mathrm{MM}$ para $35 \mathrm{MM}$ ) foi realizado pelo laboratório DU ART em Nova York (EUA), por ser, na época, uma tecnologia não existente no Brasil.

${ }^{24}$ Fonte: arquivo pessoal, uma vez que fui uma das produtoras executivas do filme, sendo a responsável pelo controle financeiro e pela prestação de contas junto aos órgãos financiadores estatais (BANESPA, BNDES e RIOFILME).
} 
- $\quad$ Avanço de distribuição da RIOFILME ${ }^{25}$ (no valor de US\$ 80,000.00).

Na época, a relação entre dólar e real era: $\mathrm{R} \$ 1,00=$ US\$1.00.

O total de aportes conseguidos já se mostrava insuficiente para uma produção com captação em $35 \mathrm{MM}^{26}$.

A decisão foi tomada por seus produtores para que o filme se concretizasse. Os custos de uma produção realizada em 16 MM eram bem menores e, por conta de uma inovação tecnológica que estava sendo introduzida, os acordos de coprodução e de patrocínio ficaram mais fáceis de serem fechados.

Toda a logística para a execução do projeto de produção, bem como as soluções tecnológicas usadas e administração do projeto foram seguidas a partir de decisões dos produtores. Essas decisões interferiram na estética e na estrutura narrativa do filme.

A partir desse exemplo é possível começar a delinear o perfil do produtor.

O produtor é responsável pela captação dos recursos, sua administração e pela garantia da finalização do filme.

Mas essas características ainda não dão conta de definir seu verdadeiro papel.

A Lei dos Direitos Autorais $^{27}$, de 19 de fevereiro de 1998, veio ajudar nessa definição.

"Produtor - a pessoa física ou jurídica que toma a iniciativa e tem a responsabilidade econômica da primeira fixação do fonograma ou da obra audiovisual, qualquer que seja a natureza do suporte utilizado". ${ }^{28}$

Ou seja, o produtor é o responsável pela captação e pelos investimentos necessários a todo o processo de produção até a finalização do filme.

Mais uma vez, a Lei dos Direitos Autorais vêm explicitar as responsabilidades e os direitos de cada profissional que atua nesse segmento.

\footnotetext{
${ }^{25}$ Riofilme - Distribuidora de Filmes - é uma estatal subordina à Prefeitura da Cidade do rio de Janeiro.

${ }^{26} \mathrm{Em}$ média, a produção de pequeno porte para um filme rodado e finalizado em $35 \mathrm{MM}$ girava na casa dos 600 mil dólares.

${ }^{27}$ Lei $n^{\circ} 9.610$, de 19.02.98.

${ }^{28}$ no Art. $5^{\circ}$, item número XI.

http://www.cultura.gov.br/legislacao/leis/index.php?p=36\&more=1\&c=1\&tb=1\&pb=1, último acesso em 27/01/2006.
} 
Seguindo as determinações estabelecidas pela Convenção de Berna ${ }^{29}$, a lei distingue o direito moral do direito patrimonial.

O direito moral é definido como um bem inalienável, descrito em seu Art. $25^{\circ}$ para o caso de obras audiovisuais:

"Cabe exclusivamente ao diretor o exercício dos direitos morais sobre a obra audiovisual".

O direito patrimonial é um direito intrínseco à exploração econômica da obra acabada. No Art. $22^{\circ}$ da mesma lei, está explicitado a quem pertence os direitos patrimoniais.

"Pertencem ao autor os direitos morais e patrimoniais sobre a obra que criou."

Mas, o Art. $49^{\circ}$, garante a transferência dos direitos patrimoniais a quem vai gerenciar economicamente a obra.

"Os direitos de autor poderão ser total ou parcialmente transferidos a terceiros, por ele ou por seus sucessores, a título universal ou singular, pessoalmente ou por meio de representantes com poderes especiais, por meio de licenciamento, concessão, cessão ou por outros meios admitidos em Direito, obedecidas as seguintes limitações:

I - a transmissão total compreende todos os direitos de autor, salvo os de natureza moral e os expressamente excluídos por lei."

O advogado Lincoln Antônio de Castro, especialista em direitos autorais, explica os dois artigos destacados acima:

"A exploração pode ser realizada pelo próprio autor ou por pessoa autorizada pelo autor, conforme ficar estipulado em contrato. O direito patrimonial de autor tem características diferentes daquelas relativas ao direito moral de autor, a saber: alienável; penhorável; temporário; prescritível." ${ }^{\text {30 }}$

Se por um lado e por extensão de sentido, ficou determinado pela lei que o produtor é a pessoa que responde pelos riscos do investimento, pode-se concluir que o produtor também é o detentor dos direitos patrimoniais da obra.

"A razão pela qual o produtor de um filme seja o detentor dos direitos patrimoniais decorrentes da exploração comercial da obra é compreensível porque, mesmo que

\footnotetext{
${ }^{29}$ Convenção realizada em Berna em 9 de setembro de 1886, completada em Paris a 4 de maio de 1896, revista em Berlim a 13 de novembro de 1908, completada em Berna a 20 de Março de 1914, revista em Roma a 2 de Junho de 1928, depois em Bruxelas a 26 de Junho de 1948, em Estocolmo a 14 de Julho de 1967 e em Paris a 24 de Julho de 1971, com o objetivo de estabelecer normas de âmbito mundial que visassem a proteção das obras literárias e artísticas, sendo o Brasil um dos país signatários dela, conforme a informação que consta no site da Biblioteca Nacional: http://www.bn.br/site/default.htm, último acesso em 25/01/2007.

${ }^{30}$ CASTRO, Lincoln Antônio de. Noções sobre o direito autoral. in: http://www.uff.br/direito/artigos/lac03.htm, último acesso 27/01/2007.
} 
ele não seja seu criador, é ele que arrisca seu patrimônio em um empreendimento que não Ihe dá garantias da recuperação do investimento." (Montero, 1966, p. 66).

Um filme passa por todo o processo de transformação, começando por uma idéia até se chegar a um produto final. Alguém viabilizou todo o processo com o objetivo de ter um filme acabado. A ele será a atribuída a função de produtor. Portanto, a definição mais completa para um produtor é aquela que o coloca como detentor do direito patrimonial da obra, sendo o responsável pelos investimentos necessários à sua produção, colocando dinheiro próprio ou representando um grupo de investidores, correndo os riscos na comercialização do filme e arcando com seus prejuízos em caso de insucesso.

No Brasil, em alguns momentos, o diretor do filme é quem assume os riscos do empreendimento. Ele faz o papel do produtor. Nesse caso, ele está desempenhando dois papéis, o de diretor e o de produtor e nem sempre ele assina os créditos do filme como tal, ou por preconceito de não querer ser identificado em uma "função técnica" ou por desconhecimento. $E$ isso é causa de equívocos. Defendo que, nesse caso, ele entenda seu duplo papel e coloque seu nome nas funções que, de fato, ele atuou.

O produtor comanda uma equipe de pessoas diretamente ligadas a ele, que é a equipe de produção. Ela pode ser representada da seguinte forma:

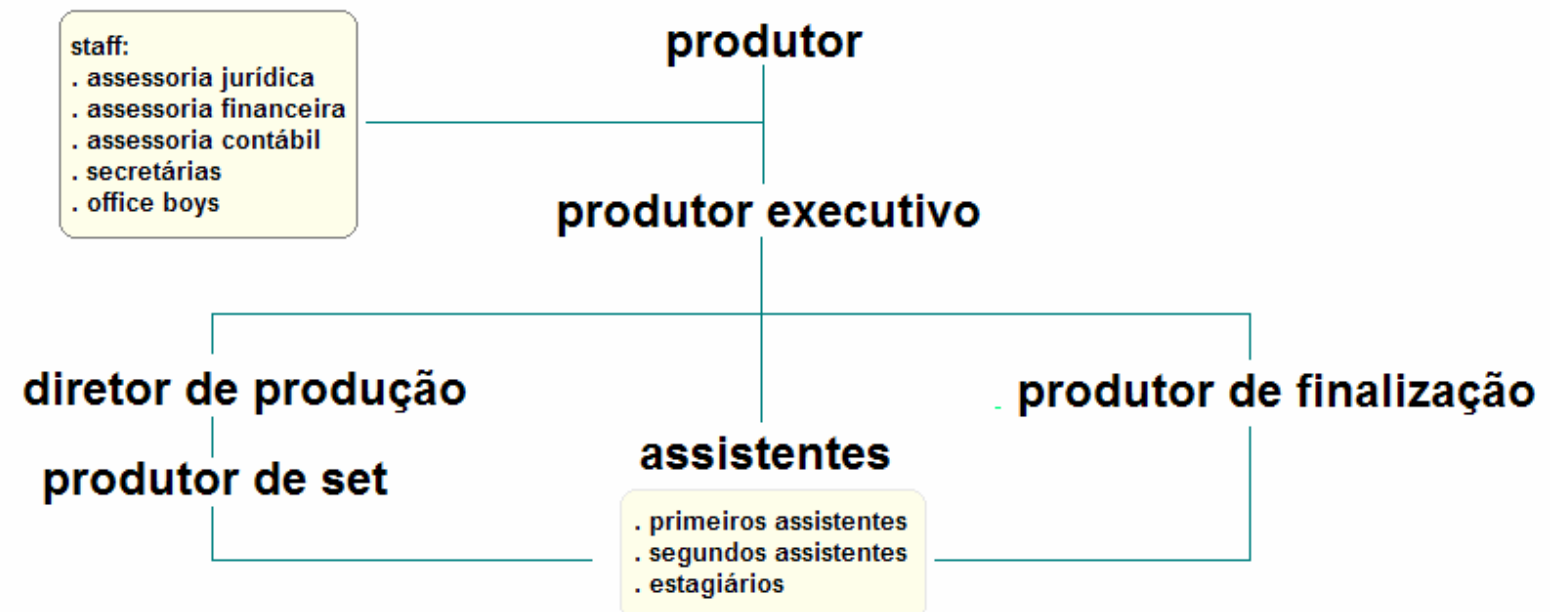

Busca-se na figura do produtor, um profissional que apresente domínio do processo de produção, da linguagem cinematográfica, além de uma grande capacidade de negociação, criatividade, iniciativa e agilidade. Para o produtor com essas características, tem- se usado a expressão "produtor criativo".

Sam Spiegel ${ }^{31}$, certa vez, definiu esse tipo de profissional, o produtor criativo, como um organizador que, ao encontrar uma história,

\footnotetext{
${ }^{31}$ Produtor independente com atuação nos Estados Unidos (Hollywood) e Europa. Considerado um dos produtores mais talentosos de sua época. Principais filmes produzidos por Sam Siegel: The night of the generals (A noite dos generais - 1964); Lawrence of Arabia (Lawrence das Arábias - 1962); Suddenly, Last Summer (De repente, no último verão - 1959); The Bridge on the River Kwai (A ponte do rio Kwai - 1957).
} 
"sente um impulso de filmá-la e, uma vez tendo conseguido um roteirista, um financiamento e um diretor, e até mesmo, quem sabe, sendo apoiado por alguém que cuide da distribuição, reúna todos, preocupando-se com a produção e possuindo uma certa dose de loucura. Controla tudo no set. É a eminência parda de um bom filme." (Sinclair, 1996, p.5).

produtor executivo

É o gestor do filme. Elabora o orçamento e as estratégias para a realização do filme. Busca as melhores soluções para compatibilizar o orçamento com as necessidades da produção. Contrata serviços, profissionais e equipamentos necessários à produção. Faz o controle da movimentação financeira gerada pelo filme. Responde diretamente ao produtor. Precisa ter um apoio de assessoria jurídica, financeira e contábil e seus assistentes Ihe dão suporte administrativo. Embora tenha o perfil de um administrador, deve ter o domínio do processo de produção e da linguagem cinematográfica, pois suas decisões interferem no filme. Tem que apresentar um caráter de negociador, capaz de aliar as necessidades artísticas com as possibilidades orçamentárias.

Uma prática comum aqui no Brasil é o produtor acumular a função de produtor executivo. Esse é o mesmo caso já citado do diretor / produtor. As funções são diferentes e complementares, mesmo quando são exercidas pela mesma pessoa.

diretor de produção

Responsável pela montagem da infra-estrutura necessária ao filme, cumprindo o plano estratégico elaborado pelo produtor executivo.

Montar a infra-estrutura significa:

- Viabilizar todas as locações que serão usadas durantes as filmagens, fechando contratos de locação ou cessão;

- Proporcionar o melhor acesso da equipe, de equipamentos e de serviços;

- Providenciar os espaços necessários à equipe da direção de arte como oficinas para a cenotécnica e cenografia, camarins para maquiadores e figurinistas.

- Providenciar os espaços necessários para a manutenção dos equipamentos de luz, câmera e som;

- Providenciar o transporte, a guarda e a segurança dos equipamentos que serão utilizados.

- Providenciar a alimentação de equipe e atores;

- Contratar os serviços de limpeza;

- Compatibilizar as necessidades da equipe técnica com as possibilidades oferecidas pela locação, por exemplo, instalações elétricas compatíveis com a carga exigida pelos refletores e outros equipamentos, quando não forem utilizados geradores externos;

- Providenciar o isolamento acústico para filmes que trabalhem com som direto;

- Garantir a segurança da equipe e artistas. 
Além disso, é o responsável pelo preenchimento e divulgação de documentos como a análise técnica do roteiro ${ }^{32}$ e a ordem do dia $^{33}$.

O diretor de produção faz o agendamento dos profissionais envolvidos nas filmagens, com agilidade suficiente para trocar a ordem de filmagem caso um imprevisto aconteça, por exemplo, chuva em dias programados para filmagens externas.

É supervisionado pelo produtor executivo e pode trabalhar com vários assistentes, que o auxiliam nessas tarefas.

produtor de set

Trabalha exclusivamente no set de filmagem visando garantir sua organização e o respeito ao cumprimento da agenda proposta.

Providencia tudo o que está listado na ordem do dia e organiza a pauta de filmagem conforme o descrito no documento.

Trabalha com assistentes que o auxiliam nessa tarefa. Responde ao diretor de produção.

\section{produtor de finalização}

Responsável pela escolha da tecnologia a ser usada, garantindo que a tecnologia escolhida para a realização do filme dê conta de todo o processo de produção. Também faz a intermediação da tecnologia analógica com a digital, se o suporte de filmagem escolhido for o $35 \mathrm{MM}$, uma vez que não existe mais, no cinema atual, a possibilidade do processo de finalização ser totalmente analógico.

Trabalha desde a etapa de preparação de filmagens até a entrega da primeira cópia. Auxilia o produtor e o produtor executivo na tomada de decisões

\section{assistente de produção}

Cada um dos produtores listados tem sua equipe de assistentes, mas, de uma forma geral, eles têm a função de auxiliar o trabalho dos produtores. O número de assistentes varia de acordo com as necessidades da produção e as possibilidades orçamentárias. Para funções que permitam algum poder de decisão dentro da hierarquia estabelecida, são convocados primeiros assistentes. Segundos e terceiros assistentes são contratados de acordo com o volume de trabalho, podendo ou não fazer parte da equipe de produção.

No esquema acima, representei a equipe de assistentes em um único quadro que auxilia a todos os produtores para facilitar a compreensão. Essa é uma configuração que também pode acontecer.

\footnotetext{
${ }^{32}$ A análise técnica é uma tabela contendo todas as necessidades para as filmagens em determinada locação. Estão listadas todas as necessidades das equipes que estarão presentes no set de filmagem (direção de arte, direção de fotografia, direção, som direto e produção).

${ }^{33}$ A ordem do dia é um documento que vai ordenar tudo o que acontecerá no dia de filmagem: A seqüência de planos a serem filmados, os horários de transporte, os profissionais que deverão estar no set e sues horários, etc.
} 
As funções necessárias a uma produção

Os profissionais que atuam na produção de um filme estão divididos em várias equipes $^{34}$.

Grosso modo, essas equipes podem ser apresentadas da seguinte forma:

equipe de produção

já descrita acima

equipe de roteiristas

- roteiristas

- dialoguistas

- pesquisadores (quando necessário)

equipe de direção

- diretor

- primeiro assistente de direção

- $\quad$ segundo assistente de direção

- continuista

- produtor de elenco

- atores

- dublês

equipe de fotografia

- diretor de fotografia

- assistente de fotografia

- operador de câmera

- primeiro assistente de câmera

- $\quad$ segundo assistente de câmera

- terceiro assistente de câmera

- operador de video assist

- eletricista chefe

- eletricista

- assistente de elétrica

- maquinista chefe

- maquinista

- assistente de maquinista

- operadores de especiais como steadycam, grua eletrônica, dollys, etc.

- responsáveis por efeitos de iluminação como raios, por exemplo

- auxiliares

equipe de arte

- diretor de arte

- assistente de direção de arte

- produtor de objetos

- cenógrafo

- cenotécnico

${ }^{34}$ Lembrando que estamos falando de produção de filmes atuais. 
- pintor

- pessoas que cuidam da parte do acabamento como azulejista, por exemplo, se o cenário construído exigir a colocação de azulejos

- auxiliares

- contra-regra

- figurinista

- camareira

- assistente de camareira

- costureira

- maquiador

- assistente de maquiador

- cabeleireiro

- assistente de cabeleireiro

- técnico de efeitos visuais como sangue, tiros, etc.

- stunts

equipe de som direto

- técnico de som direto

- microfonistas

- caboman

- auxiliares

equipe de montagem

- montador

- primeiro assistente

- operador do equipamento usado para a montagem (Avid, Final Cut, etc.)

equipe de edição de som

- sound designer

- $\quad$ editor de som (diálogos, ruídos)

- operador do equipamento usado para a edição de som (Protools, etc.)

- compositor musical

- músicos

- técnico para a gravação de ruídos de salas e efeitos sonoros

- mixador

equipe de finalização

- produtor de finalização

- colorista

- operador de telecine

\section{Etapas de produção}

A produção de um filme, como todo processo de transformação de insumos em produtos, segue um fluxo de trabalho que organiza a cadeia produtiva em fases. Anteriormente ${ }^{35}$, foi colocado um esquema reduzido para exemplificar a definição de produção feita por Chris Rodrigues. Agora, para melhor análise, o fluxo pode ser apresentado conforme figura colocada a seguir:

${ }^{35}$ Ver p. 14 


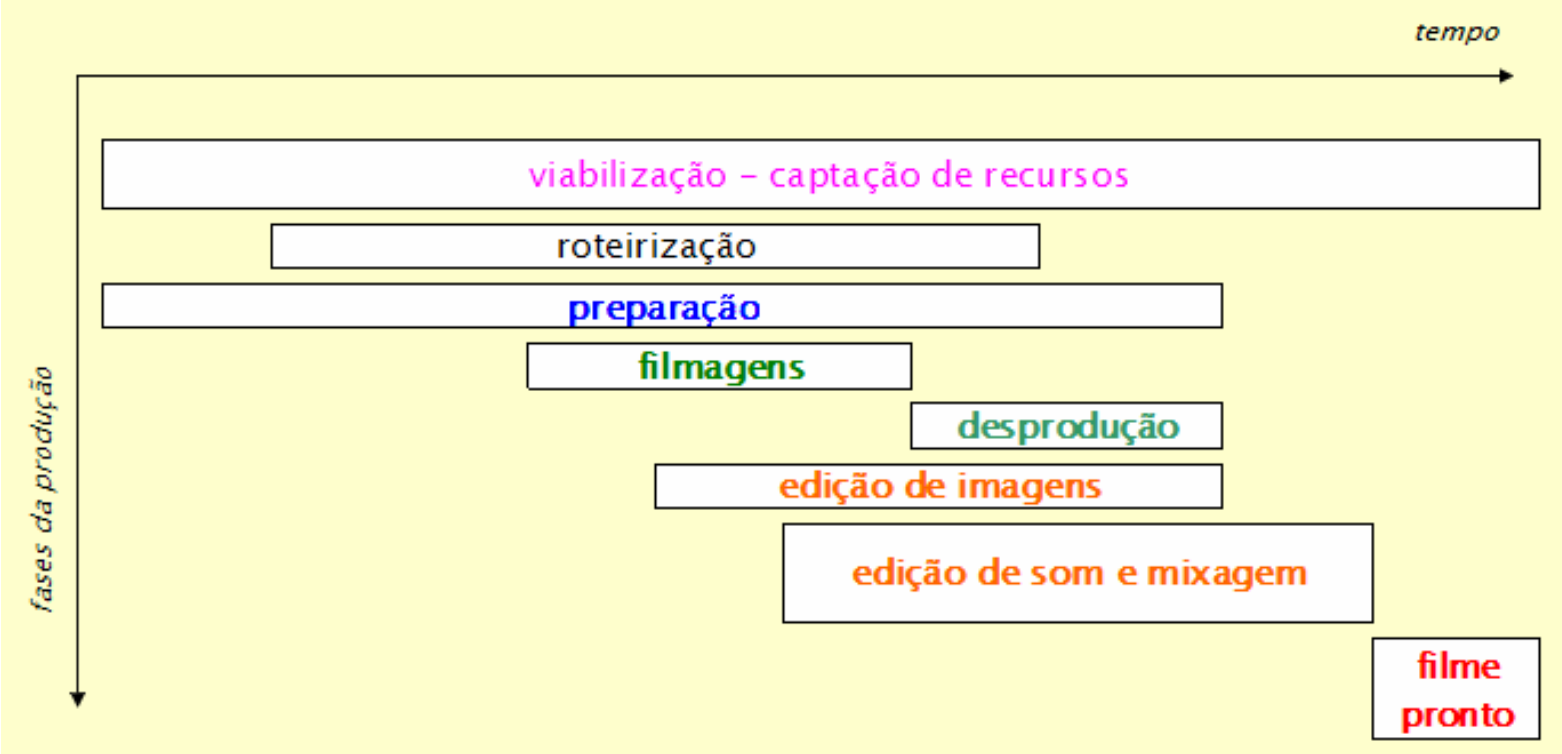

Podemos então, dividir a produção nas seguintes etapas:

- Etapa 1: Etapa de viabilização do filme e de captação de recursos

- Etapa 2: Etapa de pesquisa e de roteirização

- Etapa 3: Etapa de preparação

- Etapa 4: Etapa de filmagens

- Etapa 5: Etapa de desprodução

- Etapa 6: Etapa de montagem

- Etapa 7: Etapa de edição de som e mixagem

- Etapa 8: Etapa de finalização

Etapa 1 da produção:

Viabilização do filme e de captação de recursos

A produção, então, começa a partir do momento que as estratégias para a sua viabilização são estabelecidas.

Necessidades:

- levantamento de fontes financiadoras;

- formatação de projeto e de materiais promocionais;

- levantamento prévio orçamentário;

- captação de recursos;

- levantamento de acordos de co-produção, patrocínio e apoio; 
- levantamento de acordos de pré-venda para a distribuição do filme para o circuito exibidor.

Técnicos envolvidos:

Produtor executivo e seu staff (assessores jurídicos e contábeis, assistentes e secretárias), diretor e autor da idéia (que pode ser o roteirista, o diretor ou outra pessoa envolvida ou não na produção).

Etapa 2 da produção:

Pesquisa e de roteirização

Necessidades:

- levantamento de dados para as informações que os roteiristas se utilizam;

- pesquisa de material de arquivo, ou de referências bibliográficas ou iconográficas;

- disponibilização de material de consumo como material de papelaria, fitas de vídeo, material fotográfico, etc;

- disponibilização de infra-estrutura mínima com serviços de secretaria e de comunicação.

Técnicos envolvidos:

Roteiristas, dialoguistas, revisores, pesquisadores; produtor executivo e staff (assistentes / assessores e secretárias); diretor e assistentes.

Etapa 3 da produção:

Preparação

O termo consagrado pelo mercado e entre os técnicos para esta etapa é o de "préprodução". Mas, acredito ser um termo inadequado, pois a preparação não é anterior à produção. Ela é uma etapa que acontece durante o processo de produção. Por isso, concordo com aqueles pesquisadores que a chamam de "preparação".

É durante a preparação que as principais decisões da produção serão tomadas: as tecnologias utilizadas (analógica / digital) e suas implicações e impactos durante todo o processo. Também são tomadas as decisões em relação a elenco e ao projeto da direção de arte. Todas as ações futuras serão conseqüência dessas decisões.

Esta é uma etapa que pode ser sub-dividida em mais duas:

Pré-filmagens (organização das filmagens) e pré-finalização (organização e planejamento da edição de imagem, edição de som e finalização). Começa antes das filmagens e se estende até, praticamente, a fase do lançamento comercial do filme.

Necessidades e ações:

pré-filmagens:

- fechamento de contratos de co-produção e patrocínio;

- fechamento de acordos de cessão, empréstimo e permuta;

- pesquisa e contratação de locações e / ou construção de cenários em estúdio; 
- pesquisa e compra / locação / construção e móveis, objetos e decoração dos cenários;

- pesquisa e confecção / compra de figurinos e acessórios;

- análise técnica e decupagem de roteiro contendo as informações necessárias a todas as equipes;

- contratação de todos os serviços necessários (alimentação, transporte, etc.);

- locação de equipamentos de câmera, de som, de iluminação; de maquinaria;

- compra de material sensível e materiais de consumo;

- contratação de artistas e técnicos;

- testes e contratação de elenco e figuração;

- preparação dos atores: ensaio e testes de fotogenia, maquiagem e figurino;

- preparação e organização de plano de produção com a ordem de filmagem (ordem do dia) estabelecida preferencialmente por locação;

- planejamento com mobilidade suficiente para ser mudado em prazos de tempo muito curtos;

- disponibilização de infra-estrutura mínima necessária;

- fechamento de contratos de distribuição,

Técnicos envolvidos:

Equipe de roteiristas, produtor executivo e staff, diretor de produção e assistentes, produtor de finalização e assistentes, diretor e assistentes, diretor de fotografia, diretor de arte (cenógrafo, figurinista e assistentes), técnico de som.

pré-finalização

- compras de imagens e sons produzidos por outros que venham a ser usados no filme que está sendo produzido;

- definição das janelas de exibição do filme conforme os acordos assinados;

- contratação de serviços de finalização (edição - imagem e som, telecine, finalizadoras, etc.)

- contratação de serviços que trabalharão para a divulgação do filme a partir de seu lançamento.

Técnicos envolvidos:

Produtor executivo e staff, diretor de produção e assistentes, produtor de finalização e assistentes, diretor e assistentes e prestadores de serviços (assessoria de imprensa, serviço de relações públicas, agências de publicidade, etc.)

disponibilização

Etapa 4 da produção:

Filmagens

As etapas subseqüentes são etapas de execução do planejamento. As ações compreendem o cumprimento de um plano elaborado prevendo ações diárias.

Necessidades e ações:

- ampla divulgação da informação, organizada em forma de planilhas chamadas de ordem do dia para todos os técnicos e artistas envolvidos no processo;

- respeito aos critérios de filmagens estabelecidos durante a preparação;

- disponibilização de infra-estrutura mínima necessária. 
Técnicos envolvidos:

Equipe de roteiristas, produtor executivo e staff, diretor de produção e assistentes, produtor de finalização e assistentes, diretor e assistentes, diretor de fotografia e staff, diretor de arte (cenógrafo, figurinista e assistentes), técnico de som e assistentes.

Etapa 5 da produção:

Desprodução

Para a parte de desmontagem da infra-estrutura, devem ser previstas as seguintes ações:

- checagem e devolução de material locado, cedido ou emprestado;

- decisão sobre destino de material comprado;

- acerto e baixa de contratos trabalhistas temporários;

- quitação das obrigações trabalhistas e recolhimento de impostos;

- desmonte de cenários e locações;

- fechamento de fluxo de caixa e prestação de contas (primeira parcial).

- disponibilização de infra-estrutura mínima necessária.

Técnicos envolvidos:

produtor executivo e staff, diretor de produção e assistentes, assistente de câmera, eletricistas, maquinistas e assistentes, cenógrafo, figurinista e assistentes, microfonista e assistentes.

Etapa 6 da produção:

Montagem

Necessidades e ações:

- contratação dos serviços necessários a essa fase;

- aprovação do corte final.

Técnicos envolvidos:

Produtor executivo e staff, produtor de finalização, editor de som, sincronizadores e assistentes, diretor e staff, montador e staff.

Etapa 7 da produção:

Edição de som e mixagem

Necessidades e ações:

- contratação de serviços necessários;

- aprovação da trilha musical;

- aprovação da edição de som e da mixagem.

Técnicos envolvidos:

Produtor executivo e staff, produtor de finalização, diretor e staff, editor de som e staff, músicos e compositores. 
Etapa 8 da produção:

Finalização

Ações:

- contratação dos serviços de produção de efeitos, créditos e legendas;

- aprovação da primeira cópia no suporte planejado.

Técnicos envolvidos:

Produtor executivo e staff, produtor de finalização e staff, diretor e staff, diretor de fotografia e terceiros.

\section{A organização da equipe dentro dos modelos de produção ${ }^{36}$}

O modelo de produção praticado hoje baseia-se no package-unit, que foi implantado pela indústria cinematográfica norte-americana ainda na década de 1950 e só implantado no Brasil a partir da década de 1990. Essa organização se dá para a produção de um projeto.

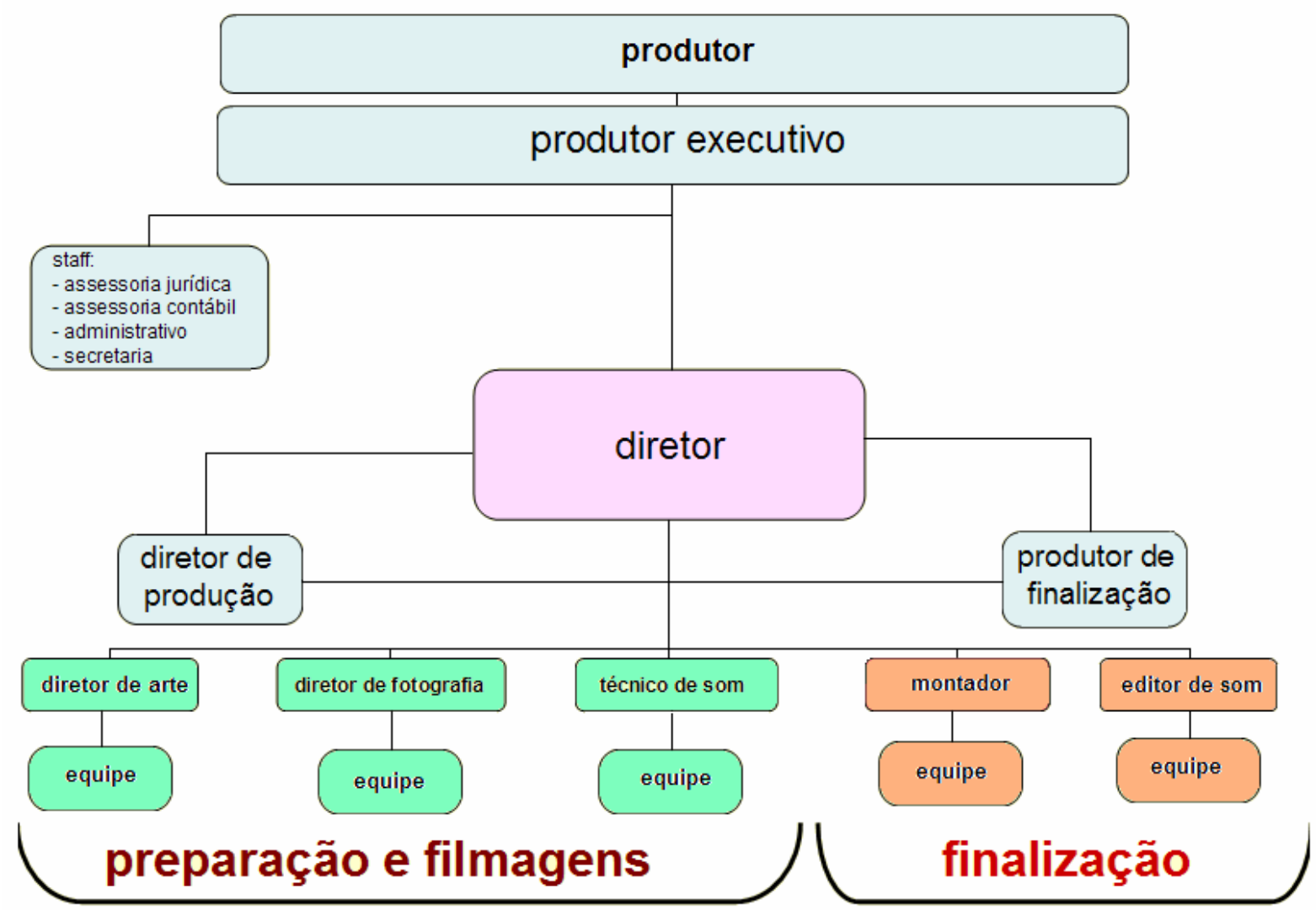

Os outros modelos praticados ao longo da história traziam diferenças de nomenclatura, mas mantinham as mesmas funções e a mesma organização da equipe.

${ }^{36}$ Os vários modelos de produção existentes foram praticados em épocas diferentes ao longo da história do cinema brasileiro. Quando abordar os diversos ciclos cinematográficos brasileiros, explicarei qual foi o modelo utilizado e como ele funcionava. 
No chamado "cinema de autor", o autor assume as funções do produtor, do diretor, e, em muitos casos, o do roteirista, enquanto o produtor creditado faz o papel do produtor executivo e diretor de produção. O esquema colocado a seguir exemplifica a organização da equipe.

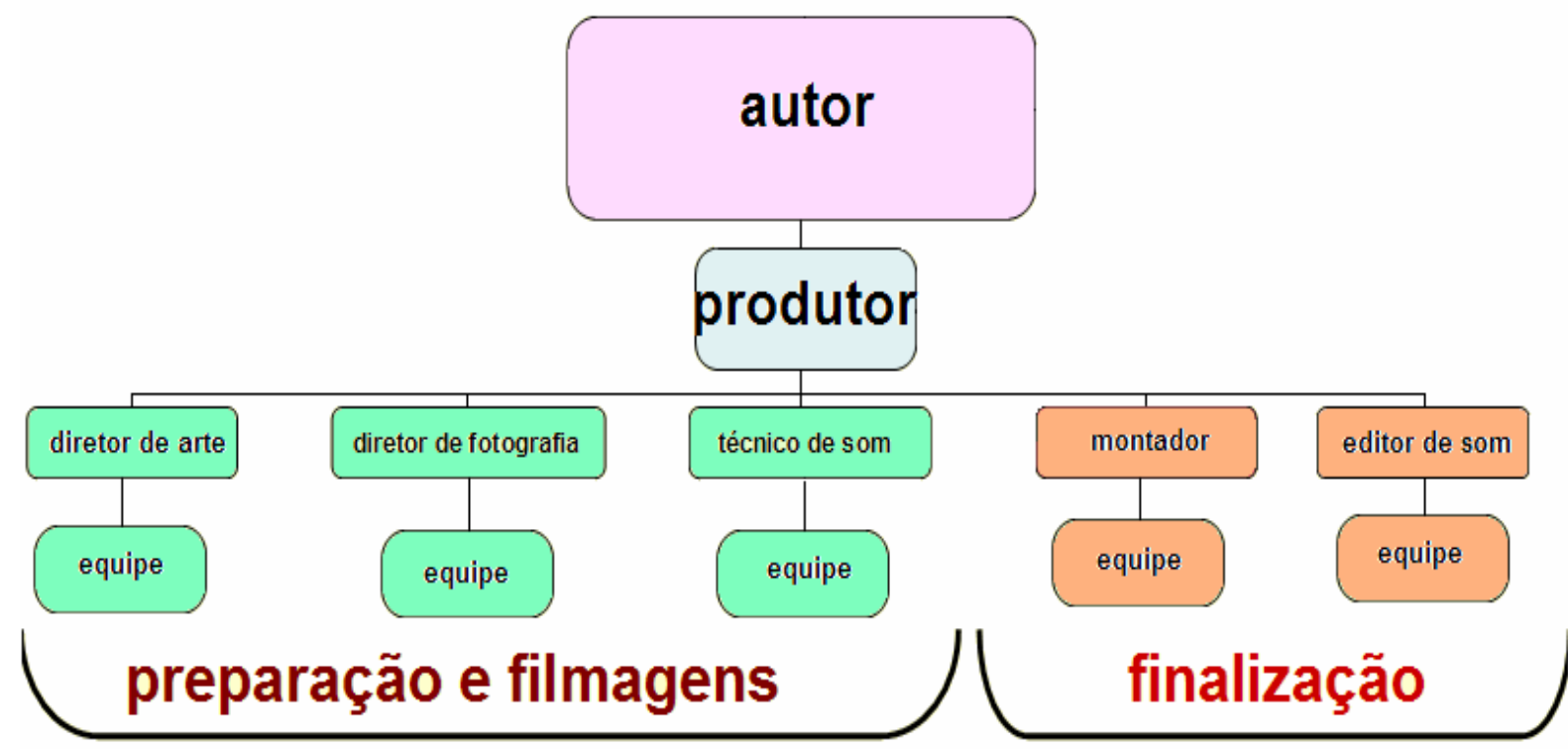

Já na época de ouro dos estúdios "hollywoodianos", onde a produção de filmes era feita em escala industrial, e cada chefe de estúdio comandava a equipe de filme, a organização das equipes se dava da seguinte forma ${ }^{37}$.

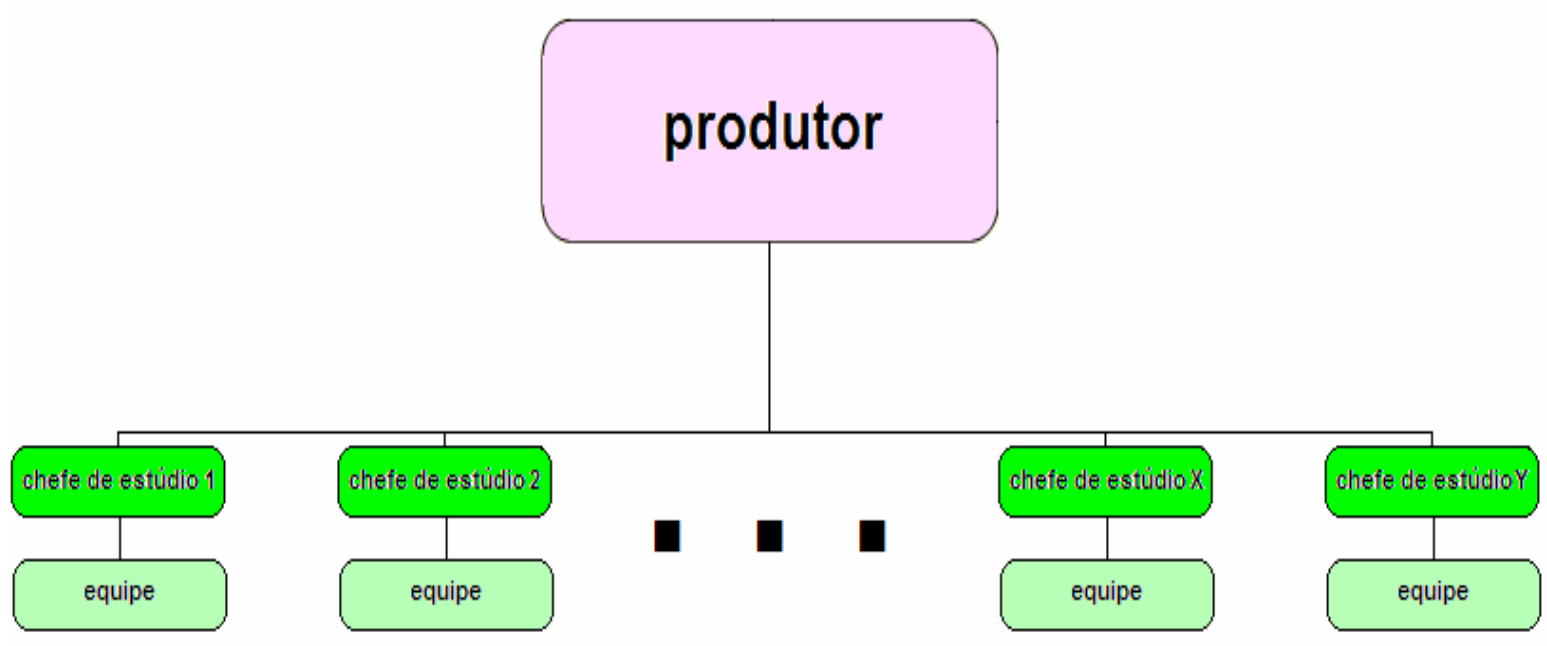

Independente do modelo adotado, funções como iluminação e operação de câmera, por exemplo, sempre existirão e continuarão a existir enquanto houver formas de expressão audiovisual. Essas funções podem sofrer variações em suas nomenclaturas, mas a produção de longas metragens sempre precisará de uma câmera para se realizar.

\footnotetext{
${ }^{37}$ A televisão ainda usa esse modelo, mas a nomenclatura é diferenciada.
} 
A tecnologia do cinema vive em constante aprimoramento. Hoje, passamos por radicais transformações, pois estamos prestes a sair do suporte película e entrar na era da alta definição digital. É prematuro dizer se o modelo de produção também sofrerá uma radical mudança. Isso ficará para o futuro. 


\section{capítulo 2: O cinema brasileiro - Panorama histórico ${ }^{38}$}

\section{Ciclo da Belle Époque ${ }^{39}$ (ou Ciclo da Bela Época)}

É o período que Paulo Emílio definiu como o intervalo compreendido entre os anos de 1896 a 1912 e concentrado na cidade do Rio de Janeiro, onde os filmes curtos foram produzidos, em sua grande maioria, pelos proprietários de salas de espetáculos ou pelos ambulantes donos de equipamentos de exibição. Os pioneiros foram os imigrantes europeus, sendo o grupo de italianos, o de maior número.

Os empresários donos das salas exibidoras tomaram a iniciativa de importar equipamentos e aprenderam as técnicas de filmagem. Também faziam a revelação de negativo e bancavam todos os custos para que pudessem realizar seus filmes. Esse é o perfil de nosso primeiro produtor, durante todo o ciclo da Belle Époque.

É possível fazer ainda uma subdivisão desse período em mais duas partes: uma primeira, que vai de 1896 a 1907, e uma segunda, de 1908 a 1912. Um fato histórico é o evento que divide o período: em 1907 entra em operação a primeira usina construída no Brasil capaz de gerar energia elétrica em escala industrial.

Os filmes da primeira etapa, ou seja, anteriores a 1907, limitavam-se a mostrar imagens cotidianas ("vistas animadas") em seções esparsas e descontinuadas. Supõe-se que as cenas filmadas no Brasil só começaram a ser exibidas a partir de 1899 eram imagens que mostravam pontos importantes da cidade do Rio de Janeiro como o Largo do Machado, a Igreja da Candelária ou cenas de solenidades como a visita do presidente da República ao cruzador Benjamin Constant, por exemplo.

A partir de 1097, os primeiros filmes de enredo (ou "filmes posados") foram produzidos. O filme Nhô Anastácio chegou de viagem ${ }^{40}$ foi, provavelmente, a primeira produção de ficção feita no Brasil. Não se tem registro de tentativas anteriores. Mas, o fato que interessa, é que, após essa data, a realização de filmes de ficção, e sua conseqüente projeção, tornou-se contínua e vigorosa.

A produção dos filmes continuou sendo feita pelas pessoas que possuíam salas exibidoras e essa foi a chave para o sucesso de um ciclo de cinema tão efervescente: o empresário que produzia seu filme tinha a segurança de ter um espaço onde o público espectador pagava seus custos. E o lucro possibilitava a realização do próximo filme.

\footnotetext{
${ }^{38}$ Opto pela expressão "ciclo" por considerar que a produção de filmes no Brasil gira em círculos, partindo de um ponto e voltando para o mesmo lugar, não importando o tempo que leva para fechar a circunferência.

${ }^{39}$ A insistência de Paulo Emílio em cravar a expressão "Belle Époque" no original francês deve-se, segundo Jean-Claude Bernardet, à sua maneira de comentar o mundanismo das muitas atrizes que vieram da Europa para arriscar sua sorte. Essas atrizes e outros tantos aventureiros vieram em função de um "boom" da produção cinematográfica e provocaram alarde e euforia, registrados pela imprensa contemporânea com artigos transcritos na maioria das obras consultadas.

40 Filme produzido e exibido em 1908, realizado por Julio Ferrez, filho de Marc Ferrez, fotógrafo francês, exibidor e representante brasileiro da Gaumont e da Pathé. Era uma comédia e teve boa aceitação popular.
} 
"Tal entrosamento entre o comércio de exibição cinematográfica e a fabricação de filmes explica a singular vitalidade do cinema brasileiro entre 1908 e 1911." (Gomes, 2001, pág. 24).

Concentraram-se no Rio de Janeiro os maiores produtores/exibidores existentes até então como os próprios Segreto, os Ferrez (de origem francesa), Antonio Leal (imigrante português) e suas empresas Fotocinematografia Brasileira (produtora) e Cinema Palace (sala exibidora).

Leal foi o maior produtor da época e dominou a exibição com o lançamento freqüente de títulos novos. Passeou por todos os gêneros cinematográficos como dramas e melodramas, comédias, épicos, policiais e musicais ("filmes cantantes"). Encontrou seus maiores sucessos quando adaptou para as telas histórias verídicas, reproduzindo crimes espetaculares que chocaram a sociedade brasileira como Os estranguladores ${ }^{41}$ e $A$ mala sinistra ${ }^{42}$.

Graças ao desenvolvimento de tecnologias de exibição que permitiam aos filmes silenciosos alguma possibilidade de reprodução de som, filmes musicais, baseados em óperas e operetas, começaram a ser produzidos ${ }^{43}$. O sucesso é imediato e traz mais público às salas de exibição.

Um outro ponto que deve ser destacado para melhor compreensão da evolução do pensamento produtor/exibidor da época foi o surgimento dos primeiros profissionais especializados em áreas da produção. Argumentistas, cinegrafistas e diretores de cena começam a ser necessários à feitura de um filme. A equipe tem que crescer.

À medida que a tecnologia importada se desenvolve, a produção vai ficando mais complexa e cara. No Brasil, ainda não existem iniciativas significativas que permitam o desenvolvimento de materiais e equipamentos alternativos às tecnologias estrangeiras.

\footnotetext{
${ }^{41}$ Filme de 1908, que, segundo Carlos Roberto de Souza, foi exibido em mais de oitocentas seções contínuas.

${ }_{42}$ Ainda segundo Souza, nesse outro filme, também produzido em 1908, Leal filmou a reconstituição de um famoso crime acontecido em São Paulo e descoberto em Santos. O fato teve tanta repercussão nacional que motivou outras versões como o filme $O$ crime da mala (realizado por Francisco Serrador), mas Leal foi o produtor/exibidor que obteve o maior êxito.

${ }^{43}$ Aqui cabe um primeiro parêntese: o cinema de ficção nunca existiu sem qualquer tipo de imagem e som na mesma seção. Os filmes de enredo não eram mudos; eles sempre tiveram algum tipo de som. O grande problema na época era resolver questões que dependiam de desenvolvimento tecnológico: como gravar, reproduzir e amplificar o som em sincronia com a imagem que estava sendo projetada. Tecnologias estavam sendo inventadas e testadas. Nessa época, a prática mais comum era a de se contratar atores, cantores ou músicos que interpretavam músicas e falas "ao vivo", e ao mesmo tempo em que o filme era projetado. Paralelamente, as companhias desenvolviam aparelhos que reproduziam sons independentes dos projetores, como, por exemplo, gramofones acoplados a projetores. Foram essas experimentações que possibilitaram a produção dos "filmes cantantes" (musicais).
} 
O principal fato que fez com que a Belle Époque conhecesse seu declínio foi a chegada de uma missão diplomática patrocinada pelo governo norte-americano, com o objetivo de vender produtos industrializados. Filmes eram um dos produtos a serem comercializados $^{44}$. Serrador ${ }^{45}$, já constituído como um produtor/exibidor no Rio, foi um dos primeiros empresários a perceber que os lucros que o cinema poderia proporcionar eram maiores para quem cuidava da intermediação entre produtor e exibidor. Logo deixava a produção para se dedicar exclusivamente à importação e à comercialização (revenda) de filmes norte-americanos, com a sua Companhia Cinematográfica Brasileira ${ }^{46}$.

“- E as fitas nacionais? A companhia não as exibirá? perguntaram à Companhia Cinematográfica Brasileira. Um dos diretores respondeu: - Também. Mas a Companhia procurará fitas com a mesma perfeição das [fitas de] fábricas estrangeiras." (Souza, 1998, p. 65).

Por outro lado, em São Paulo, uma cidade ainda sem sinais de manifestações artísticas que pudessem concorrer com o brilho da capital federal, a origem do cinema e o modelo de produção foram semelhantes. Antonio Campos e João Stamato eram os produtores/exibidores que mais se destacavam, mas ficaram restritos à cidade e tiveram alcance regional. A chegada de filmes norte-americanos também amputou qualquer tentativa de produção cinematográfica. Mesmo enquanto se tornava um importante pólo econômico, por conta do plantio e comercialização do café, privilegiou a lavoura cafeeira em detrimento de sua incipiente industrialização.

Para reforçar que idéia de que nossa produção se dá através de períodos cíclicos, exemplifico com a tabela 1 , que coloco a seguir, a quantidade de filmes produzidos durante os primórdios do cinema. Os dados apresentados foram obtidos a partir de pesquisas feitas por Anita Simis e retratam a evolução da produção de filmes deste período. Como a própria autora revela em nota final (Simis, 1996, p. 303), ela compilou os dados a partir de informações contidas no Guia de Filmes ${ }^{47}$, porém,

\footnotetext{
44 Theodore Roosevelt (presidente dos EUA de 1901 a 1909), foi quem construiu as bases de uma política externa intervencionista e expansionista, vigente até hoje, E seus sucessores, William Taft e Woodrow Wilson, sedimentaram a Doutrina Monroe e a chamada Diplomacia do Dolar que, basicamente, impunham a moeda norte-americana como a moeda de troca no mercado internacional com o apelo da urgência em estabelecer, nas Américas, estados democráticos com economias abertas e livres de corrupção. Isso possibilitou o fortalecimento de sua indústria interna e o domínio dos mercados externos, principalmente os mercados dos países da América Central (considerados militarmente estratégicos para sua política expansionista) e da América do Sul (sob domínio dos europeus, principalmente ingleses e franceses), mas com a incômoda liderança da Argentina que começava um processo de insurgência contra a dominação estrangeira. A construção e abertura da economia brasileira eram fundamentais para as pretensões norte-americanas, o que fazia com que as missões diplomáticas de comércio de seus produtos industrializados fossem agressivas e, ao mesmo tempo, sedutoras. Missões como essas foram sempre bem-sucedidas e são importantes para compreendermos o processo histórico de construção da indústria cinematográfica brasileira.

${ }^{45}$ Francisco Serrador, imigrante espanhol, começou sua trajetória cinematográfica em São Paulo, mas transferiu-se para o Rio de Janeiro em 1910 e foi lá que, a partir da missão diplomática norteamericana, montou a maior rede exibidora do país, permanecendo neste posto por muitas décadas.

${ }^{46}$ Serrador construiu suas salas de cinema ao mesmo tempo em que produzia seus filmes para serem exibidos em suas salas. A partir da vinda da missão norte-americana, tornou-se importador fundando a Companhia Cinematográfica Brasileira. Além de exibir os filmes americanos em suas salas, ele também passou a revendê-los para os donos de outras salas.

${ }^{47}$ Série de fascículos publicados pela Embrafilme, entre 1984 a 87.
} 
pede que seja considerada alguma imprecisão em função da impossibilidade de provar a procedência de algumas fitas e sua correta duração.

tabela $1^{48}$

\begin{tabular}{llllll} 
& & & \multicolumn{3}{l}{ não } \\
& curtas & longas & ficções & ficções & total \\
\hline 1897 & 3 & & 3 & 3 \\
\hline 1898 & 9 & & 12 & 12 \\
\hline 1899 & 21 & & 2 & 22 & 24 \\
\hline 1900 & 26 & & & 27 & 27 \\
\hline 1901 & 11 & & & 12 & 12 \\
\hline 1902 & 1 & & & 1 & 1 \\
\hline 1903 & 5 & & & 7 & 7 \\
\hline 1904 & 2 & & & 7 & 7 \\
\hline 1905 & 5 & & & 7 & 7 \\
\hline 1906 & 8 & & & 11 & 11 \\
\hline 1907 & 30 & & 1 & 39 & 40 \\
\hline 1908 & 163 & & 70 & 122 & 192 \\
\hline 1909 & 169 & & 103 & 121 & 224 \\
\hline 1910 & 149 & 1 & 46 & 131 & 177 \\
\hline 1911 & 117 & 1 & 11 & 139 & 150 \\
\hline 1912 & 98 & & 7 & 122 & 129 \\
\hline 1913 & 72 & 1 & 3 & 88 & 91 \\
\hline 1914 & 46 & 1 & 5 & 50 & 55 \\
\hline & & & & & \\
\hline 1904
\end{tabular}

legenda

$\square$ Energia elétrica intermitente

Energia elétrica constante

Começam as importações de filmes norte-americanos

${ }^{48} \mathrm{Fiz}$ um pequeno resumo dos dados apresentados por Simis e não considerei relevante, para esta exemplificação, o número de filmes que não possuem especificações quanto ao tempo, origem e gênero. Mantive o total. Por isso existem diferenças quando se faz o somatório. 
A Belle Époque terminou principalmente por conta de uma ação política dos Estados Unidos, travestida de um negócio comercial altamente rentável a um grupo de pessoas (os distribuidores que compravam filmes no mercado externo e revendiam aos exibidores nacionais).

Nesse momento, os produtores já não tinham mais a quem vender seus filmes. Esse é o primeiro problema que se eternizou na produção brasileira.

Paulo Emílio Salles Gomes em seu ensaio sobre o cinema brasileiro ${ }^{49}$ apontou uma série de fatores que fazem com que nossa produção seja cíclica.

Transcrevo o que considero a mais contundente reflexão sobre os problemas que o cinema brasileiro desde sempre enfrentou.

Embora esse trecho não se refira especialmente ao cinema da Belle Époque, ele se encaixa perfeitamente nesse período e em todos os outros que abordarei adiante:

"Em cinema, o subdesenvolvimento não é uma etapa, um estágio, mas um estado: os filmes de países desenvolvidos nunca passaram por essa situação, enquanto os outros tendem a se instalar nela. O cinema [brasileiro] é incapaz de encontrar dentro de si próprio energias que the permitam escapar à condenação do subdesenvolvimento, mesmo quando uma conjuntura particularmente favorável suscita uma expansão na fabricação de filmes." (Gomes, 2001, p. 85).

\section{Ciclos regionais}

Faço, a partir de agora, um panorama geral de algumas manifestações cinematográficas acontecidas no país durante o período compreendido entre os anos de 1912 a 1932. Foram experiências restritas aos limites geográficos de cada região, com exceção da produção carioca e da experiência dos mineiros de Cataguases.

Possibilitaram uma mínima produção de filmes pelo país, durante, pelo menos, um período de duas décadas.

Apresentavam características de produção comuns e o desejo de citá-las vem não só de sua importância histórica. Foram tentativas de estabelecimento de uma indústria complexa que, regionalmente, repetiu os mesmos erros que o cinema brasileiro cometeu ao longo de todos esses anos que estou abordando.

Essa produção começava com iniciativas pessoais, aventureiras ou apaixonadas, envolvia um grupo de pessoas (e em algumas situações, uma cidade inteira), e terminava por falta de um projeto político, mesmo que regional.

\footnotetext{
${ }^{49}$ Cinema: trajetória no subdesenvolvimento, ensaio escrito na década de 70 , que impactou toda a geração cinemanovista e que se constitui em uma das mais completas reflexões a respeito do cíclico cinema brasileiro e das possibilidades de se estabelecer uma indústria cinematográfica no Brasil.
} 
Rio de Janeiro

Após o colapso da Belle Époque, a produção de filmes foi pequena embora a atividade cinematográfica crescesse consideravelmente com a exibição dos filmes estrangeiros.

Paulo Emílio, em sua proposta de periodização, divide esse intervalo de tempo em duas etapas: de 1912 a 1922, com uma produção quase que inexistente, e outra, de 1923 a 1932, trazendo a volta de uma produção um pouco mais vigorosa.

Como foi mostrado, a partir de 1912, os proprietários das salas de exibição foram deixando de produzir filmes e compravam os filmes oferecidos pelas importadoras. Os responsáveis pelo mínimo da produção existente foram os técnicos formados na primeira década do século que insistiram em continuar nessa atividade. Eles voltaram a filmar as chamadas "vistas animadas" e encontraram trabalho nas encomendas feitas por governantes, empresários ou famílias abastadas.

Limitaram-se à produção de filmes curtos (shorts), que poderiam ser cine-jornais, clips musicais, festas familiares, inaugurações, etc. Trabalharam sob encomenda e tinham como característica a venda feita diretamente ao cliente consumidor. Ficaram conhecidos como "cavadores" e este é o perfil do produtor dessa década: Com o dinheiro pago pelo cliente, faziam o serviço de filmagem e os serviços laboratoriais. Contaram com os equipamentos e laboratórios adquiridos na época da Belle Époque.

A respeito do período compreendido entre os anos de 1912 a 1922, Paulo Emílio conclui:

"Ficou claro que no Brasil o único cinema possível era o natural. É a partir dessa melancólica situação de fato que se iniciará a terceira época do filme brasileiro de enredo" (Gomes, 2001, p. 50).

No período definido por Paulo Emílio como sendo o terceiro (1923-1932), Paulo Benedetti, de origem italiana, depois de perambular pelo Brasil exibindo filmes e produzindo alguns curtas, fixa-se no Rio abrindo um laboratório de sincronização de som e imagem, na tentativa melhorar a qualidade dos filmes silenciosos produzidos até então. Une-se ao jovem Adhemar Gonzaga para fotografar Barro humano ${ }^{50}$.

Gonzaga, vindo de uma família abastada, teve a oportunidade de viajar aos Estados Unidos e estagiar em estúdios de Los Angeles. Suas idéias sobre a produção cinematográfica culminam na fundação da revista Cinearte ${ }^{51}$.

A revista se notabiliza por uma campanha constante e massiva contra o pouco cinema produzido no país até aquele momento, considerado muito ruim, e enaltece o modelo de produção norte-americano.

\footnotetext{
${ }^{50}$ Longa metragem silencioso realizado em 1929, produzido e dirigido por Adhemar Gonzaga. Faziam parte da equipe do filme, além de Benedetti, os jovens intelectuais Pedro Lima, Paulo Vanderley e Álvaro Rocha que escreviam críticas e resenhas de filmes estrangeiros para os periódicos cariocas da época.

${ }^{51}$ A Cinearte foi a revista sobre cinema de maior circulação na América do Sul. A primeira edição é de 3 de março de 1926. Circulou até 1942.
} 
"Um cinema que ensina o fraco a não respeitar o forte, o servo a não respeitar o patrão, que mostra caras sujas, barbas crescidas, aspectos sem higiene alguma, sordices e um realismo levado ao extremo não é cinema.

Imaginem um casal de jovens que vão assistir um filme americano médio. Vêem lá um rapaz de cara limpa, bem barbeado, cabelo penteado, ágil, bom cavaleiro. E a moça bonitinha, corpo bem-feito, rosto meigo, cabelos modernos, aspecto todo fotogênico. Depois há o cômico e o vilão, que também são higiênicos e distintos. $E$ ainda uma fazenda moderna, fotogênica, os subordinados se submetem aos seus superiores com alegria e com satisfação, e um ritmo que é o ritmo da vida de hoje, ágil, leve, moderno...

O parzinho que assistir o filme comentará que já viu aquilo vinte vezes. Mas sobre seus corações que sonham, não cairá a penumbra de uma brutalidade chocante, de uma cara suja, de um aspecto que tira qualquer parcela de poesia e de encantamento. Essa mocidade não pode aceitar essa arte que ensina a revolta, a falta de higiene, a luta e a eterna briga contra os que têm o direito de manda." (Souza, 1998, p. 81) ${ }^{52}$.

Estamos no comecinho na década de 30 e continuamos aqui buscando o mesmo o padrão de "qualidade" dos filmes norte-americanos que ainda dominam o mercado exibidor brasileiro. Vale a pena notar que esse mesmo discurso sobre a excelência dos filmes norte- americanos já foi feito por um diretor da empresa de Serrador ainda na década de 1910 e está transcrito na página 34 desta dissertação.

A produção do filme Barro humano se empenha em busca de um resultado que o iguale aos estrangeiros. Gonzaga começa a trabalhar pensando no modelo de produção dos grandes estúdios que visitou e ele representará, a partir de agora, o perfil do produtor que atuará nas próximas três décadas.

O modelo de indústria que Gonzaga implantou, copiava a organização dos estúdios norte-americanos. Dirigidos por seus donos (empreendedores que investiram dinheiro próprio, assumindo sozinhos os riscos do negócio), eram chamados genericamente de produtores. A estrutura que construíram para controlar sua produção era baseada na construção de uma grande sede contendo estúdios de filmagens (vários estúdios para possibilitar a produção em massa), equipamentos próprios, elenco e equipe de técnicos com contrato de trabalho fixo. Cada produção era comandada por um chefe de estúdio ${ }^{53}$.

$\mathrm{Na}$ indústria norte-americana, tendo à frente David Selznick, nasce o conceito do produtor executivo, que tem como missão produzir o filme dentro de um parâmetro orçamentário gerando lucros ao estúdio para o qual trabalha e com controle total do filme a ser produzido.

\footnotetext{
52 O artigo está transcrito da revista Cinearte de 18 de junho de 1930, no livro de Carlos Roberto de Souza. Tirei os grifos do autor.

${ }^{53} \mathrm{O}$ termo mais comumente usado na época era produtor-chefe ou, em uma tradução mais livre, chefe de estúdio. Mas, no livro O gênio do sistema, Thomas Schatz define o que estamos chamando de produtor-chefe como produtor executivo ao se referir à maneira como David Selznick controlava as produções dos filmes que ficavam sob sua responsabilidade quando ainda estava vinculado, em 1926, à Metro-Goldwin-Mayer.
} 
A boa aceitação do público ao longa dirigido por Gonzaga lhe dá a certeza do caminho a seguir. A fundação da Cinédia ${ }^{54}$ traz consigo o ideal de ser um grande estúdio cinematográfico brasileiro, moldado a partir de suas experiências hollywoodianas, e o coloca na liderança para a construção da indústria brasileira. Além de produtor (dono da empresa), desempenha o papel do chefe de estúdio (ou produtor executivo, para usar a nomenclatura norte-americana que mais tarde vamos incorporar) e diretor.

Na função de direção, Gonzaga contará também com o diretor mineiro Humberto Mauro, com quem realiza Lábios sem beijos (1930) e Ganga Bruta (1933) ${ }^{55}$. A trajetória de Mauro será retomada na abordagem dos outros ciclos do cinema brasileiro.

"A obra significava para o cinema brasileiro um grande passo no sentido de sua industrialização. A construção dos estúdios era o resultado de vários anos de luta de Gonzaga pela efetiva implantação do cinema no Brasil. Os estúdios foram feitos para serem ocupados, como realmente sempre o foram, por todas as empresas cinematográficas, inclusive a Cinédia. A intenção era fazer cinema brasileiro, um cinema modesto, simples, mas com o desejo de agradar ao público brasileiro." (Gonzaga, 1987, p. 10).

Parecia um período de renascença, pois, além da Cinédia, várias outras companhias produtoras começaram a se estabelecer nos mesmos moldes de Gonzaga. Benedetti fundou sua própria companhia e Carmen Santos, a Brasil Vita. Outras tantas empresas, citadas por Alice Gonzaga em seu livro "50 Anos de Cinédia", também se estabeleceram nesse período. Elas alcançaram um bom êxito com a produção de filmes silenciosos.

Enquanto isso, nos países desenvolvidos, estava começando a transição do cinema silencioso para o cinema sonoro. Ainda em 1927, os irmãos Warner lançam o longa The Jazz Singer (O cantor de jazz), considerado o primeiro filme sonoro da história do cinema ${ }^{56}$. Sucesso estrondoso em seu país de origem, os Estados Unidos tentam impor a tecnologia sonora às salas que exibem seus filmes pelo mundo. Encontram resistências e polêmicas de todos os lados.

\footnotetext{
${ }^{54}$ Empresa produtora de filmes, fundada em 15 de março de 1930, construída com o dinheiro da família de Gonzaga, que contava com estúdios e parque de equipamentos importados dos Estados Unidos.

${ }^{55}$ Filme considerado obra-prima do cinema silencioso brasileiro que projeta Humberto Mauro como um dos nossos maiores cineastas. "Não tenhamos quaisquer dúvidas que este pioneiro da arte do cinema latino-americano virá um dia a impor-se como um mestre do cinema." (Sadoul, 1979, p. 203).

${ }^{56}$ Considerado o primeiro sonoro porque é a primeira vez que falas são originais e integrais e estão em sincronia com a imagem projetada. Para que os estrangeiros entendessem o inglês cogitava-se o uso de legendas sobrepostas à imagem, que apareceriam e desapareceriam no ritmo das falas originais.
} 
Por possuírem uma cinematografia já bastante significativa e desenvolvimento tecnológico em estágio avançado, países como França, Inglaterra e Alemanha começam a elaborar leis de proteção à sua produção e às suas indústrias de equipamentos e materiais ${ }^{57}$. Essas leis já restringiam a exibição de filmes estrangeiros e procuravam manter a produção dos filmes nacionais aquecida.

Por aqui, nossos cineastas e intelectuais comemoraram o surgimento do cinema sonoro, pois acreditavam que o público brasileiro rechaçaria o novo formato de projeção imposto que trazia legendas sobrepostas a cada fala de um personagem, traduzindo imediatamente os diálogos falados em inglês para o português.

O "crack" da bolsa de Nova lorque, reduzindo a produção de filmes norteamericanos por um curto período, ajudou a manter o clima de otimismo entre os produtores cariocas.

Mas essa retração durou até meados da década de 30. O cinema foi a principal indústria utilizada para reerguer sua economia. Conseguindo pagar seus custos de produção no mercado interno, era fundamental voltar a dominar os mercados de outros países para manter a sustentabilidade de sua economia. Voltou ao Brasil sem quaisquer resistências.

Nesse momento, os Estados Unidos propuseram um novo modelo de negócios. Os importadores, além de Serrador, deixariam de comprar as cópias dos filmes e passariam a alugá-las. Mas a locação só poderia ser feita em bloco, ou seja, a partir de então, para se ter um determinado título, deveria se alugar um pacote com muitos outros títulos. Assim, ao fazer a conta, o custo unitário do exemplar americano ficava irrisório quando comparado aos títulos nacionais.

Em fins de 1931, foi fundada a Associação Brasileira Cinematográfica que unia importadores de filmes e exibidores. O novo modelo de negócios oferecido mudou a configuração da distribuição e da exibição, fazendo com que fosse mais lucrativo ter o ponto exibidor.

O importador volta a exibir e a fundação de uma associação como essa favoreceu a junção exibidor/distribuidor. As salas se readequaram rapidamente ao cinema sonoro já com o som ótico incorporado ${ }^{58}$. Complexos de salas luxuosas foram construídos no Brasil pelas grandes companhias produtoras como Metro e Paramount, e Francisco Serrador construiu a Cinelândia, com a idéia de transformar

\footnotetext{
${ }^{57}$ Os países subdesenvolvidos (principalmente os latino-americanos) migravam sua dependência econômica da Europa para os Estados Unidos. A Diplomacia do Dólar surtia efeitos. A Europa empobrecia e esse foi um dos principais fatores que inflamavam as posturas mais nacionalistas. Cineastas como Clair, Renoir, Vigo, Lang, Murnau, Pabst e empresas como a Eclair, Arrifelx, Agfa e Kodak, entre outros de origem européia, se fortaleceram com a ajuda de seus governos e de suas políticas protecionistas. Mas, e ao mesmo tempo, o discurso nacionalista também favorece a ascensão de governos nacionalistas representados Hitler, Franco e Mussolini. O momento político vivido pela Europa anuncia uma guerra iminente. O cinema, em conseqüência dessas proteções, será instrumento de propaganda governamental e provocará, mais tarde, o êxodo dos artistas europeus (principalmente os alemães). Mas é na transição da década de 20 para a década de 30, que o cinema europeu se fortalece.

${ }^{58}$ A partir da projeção ótica, os brasileiros demoraram muito tempo para se adaptar a essa tecnologia, o que permitiu uma maior ocupação do cinema sonoro estrangeiro.
} 
a Praça Floriano (no centro do Rio) em uma Times Square carioca. O Cine Odeon, dentro da Cinelândia, foi a maior e mais moderna sala de cinema existente em seu tempo.

O cinema sonoro se impõe e assim se encerra o ciclo de produção de filmes silenciosos no Rio de Janeiro.

A rápida euforia dos produtores cariocas foi substituída pelo desânimo.

São Paulo, Pernambuco, Minas Gerais e Rio Grande do Sul

Embora o panorama traçado na parte relativa ao Rio de Janeiro dê conta de explicar como foi a produção cinematográfica no Brasil durante o ciclo do cinema silencioso, pois as experiências de produção regionais foram parecidas, é importante apontar o que acontecia em outras regiões. A produção carioca estava restrita à capital federal no sentido que os filmes eram manufaturados lá, mas as cópias de seus filmes circularam por outras regiões do país, ao contrário das iniciativas regionais.

Em todos os ciclos regionais, o modelo de produção começava com a iniciativa dos aspirantes a cineastas que compravam seus equipamentos de filmagens e, ajudados por comerciantes, exibiam o filme pronto ao público local. A renda arrecadada durante a exibição, normalmente, pagava os custos da próxima produção.

Pernambuco foi o estado que mais produziu longas de ficção e sua produção ficou concentrada na cidade de Recife ${ }^{59}$. Os filmes, inicialmente financiados por seus criadores, ao serem exibidos com sucesso nos cinemas locais, pagava a produção dos seguintes. Mas, quando tentaram transpor as barreiras estaduais, fracassaram no fechado mercado exibidor nacional. Não conseguiram bancar os custos dessa empreitada e o ciclo terminou sem que os filmes pernambucanos tivessem uma maior repercussão.

No Rio Grande do Sul, a experiência concentrada em Pelotas é semelhante.

Já em Minas, a iniciativa de jovens cineastas se concentra principalmente em Cataguases, onde nasceu Humberto Mauro. Empreendedor associado aos imigrantes Pedro Cornello e a Edgar Brazil, fundou, com recursos próprios, uma companhia produtora que não só comprou equipamentos como também conseguiu construir câmeras graças à formação técnica de seus sócios. Produziu os longas Tesouro perdido (1927); Brasa dormida (1928) e Sangue mineiro (1928). Envolveu toda a cidade de Cataguases em suas produções transformando seus habitantes em atores e figurantes dos filmes. Por já ter morado no Rio, Mauro conseguiu exibir seus filmes por lá, com boa repercussão. A Cinearte apontou em Mauro um criador diferenciado. Isso fez com que ele e Brazil ${ }^{60}$ se transferissem definitivamente para 0 Rio, e Cornello abandonasse a produtora.

\footnotetext{
${ }^{59}$ Em oito anos (durante a década de 20), foram produzidos treze filmes. (Gomes, 2001, p. 59).

${ }^{60}$ Edgar Brazil, depois que se transferiu para o Rio de Janeiro, foi requisitado para fotografar os mais expressivos filmes dessa época. Tinha o domínio da tecnologia de exposição e do funcionamento das câmeras (fato raro para os profissionais da época) e é considerado o primeiro diretor de fotografia do Brasil.
} 
Já em São Paulo, as iniciativas de produção começaram a partir de 1909 e giraram em torno de Gilberto Rossi, imigrante italiano. Ele começou a filmar "posados" e não parou, apesar da falência da Belle Époque e do domínio norte-americano. Esse fato é importante porque desta forma que o cinema paulista manteve uma produção constante, mesmo que precária; produção essa que manterá os técnicos cinematográficos ativos durantes as décadas seguintes.

Em 1919, um agrupamento de jovens atores, quase todos de origem estrangeira, se junta em torno de sua empresa. Surge a Escola de Artes Cinematográficas Azzurri com importante papel que assegurará a continuidade do cinema em São Paulo, pois com o dinheiro dos alunos, Rossi financiava seus filmes e formava técnicos capazes de dominar o processo de produção. Adiante, os alunos formados fundavam outras escolas e garantiam a feitura de seus filmes desta forma.

As exibições concentravam-se em pequenas salas de bairros operários e Rossi seguia à frente como o produtor e diretor de seus próprios filmes.

Com as sucessivas crises de produção e exibição, Rossi se associou a José Medina, em meados da década de 1920, e fundou a Rossi Film. Tornaram-se os maiores produtores "cavadores" do país e garantiram a continuidade de produção por mais de duas décadas. Lançaram vários artistas como Menotti e Victor Del Picchia, Luiz de Barros, Arturo Carrari, entre outros.

Todos estes ciclos, que começaram por iniciativas pessoais, mal conseguiram ir além de suas fronteiras geográficas. Não conseguiram estabilidade financeira que propiciasse o estabelecimento de uma indústria e terminaram sendo soterrados pelo cinema sonoro industrial norte-americano.

\section{Ciclo das chanchadas}

Retomando o que aconteceu logo no início da década de 30: Golpe de estado derruba Washington Luiz e Getúlio Vargas inicia seu governo de 15 anos de duração. O cinema está deixando de ser silencioso. O desenvolvimento tecnológico encarece os custos de produção de um filme. Os norte-americanos tentam sair de sua crise financeira com a produção de filmes. Os europeus começam a proteger suas indústrias. Com a liderança de Adhemar Gonzaga, as associações classistas começam a se articular. E a produção de longas de ficção continua concentrada no Rio de Janeiro.

Já no decorrer da década de 30, a Cinédia e a Brasil Vita são as únicas empresas que sobrevivem. O modelo de produção continua copiando os estúdios americanos. Adhemar Gonzaga e Carmen Santos são os produtores / produtores executivos representativos da época. Começam as produções de nossos filmes sonoros.

Gonzaga alternou produções extremamente baratas com produções mais sofisticadas, buscando a excelência imposta por Hollywood. As produções mais baratas, feitas às pressas, foram dirigidas por Luiz de Barros e Genésio Arruda. Usavam cantores de rádios com alguma evidência para fazerem musicais 
carnavalescos de época e deram bons resultados de público ${ }^{61}$. As produções mais sofisticadas acabaram se constituindo em estrondosos fracassos.

"A década de 30 girou em torno da Cinédia, em cujos estúdios firmou-se uma fórmula que asseguraria a continuidade do cinema brasileiro durante quase 20 anos: a comédia musical, tanto na modalidade carnavalesca quanto nas outras que ficaram conhecidas sob a denominação genérica de chanchada." (Gomes, 2001, p. 73).

Carmen Santos seguiu a mesma trilha de Gonzaga como produtora da Brasil Vita. Alternou musicais com produções mais pretensiosas se associando a Humberto Mauro. Com ele, abriu duas frentes importantes de trabalho: a primeira, produzindo documentários como a série As sete maravilhas do Rio de Janeiro (entre 1934 e 1935); Sétima Feira Internacional de Amostras da Cidade do Rio de Janeiro (1934); General Osório (1935) e Pedro II (1935); filmes encomendados por governos municipais e federais, e O descobrimento do Brasil (1937), encomendado pelo Instituto do Cacau da Bahia ${ }^{62}$. E a segunda, realizando Favella dos meus amores (1935), o filme de maior público do diretor, e Argila (1940).

Nas outras regiões do país, apenas São Paulo continuou a trabalhar com seus produtores "cavadores" em documentários sonoros de encomenda.

Os documentários e o chamado cinema de "cavação" começaram a ser produções atrativas aos produtores graças à primeira grande intervenção do estado na produção de cinema no país, que aconteceu em 1932. O Presidente Vargas assina o Decreto-Lei $n^{0} 21.240 / 32^{63}$ que basicamente obriga que antes de cada exibição de um filme estrangeiro haja a exibição de um complemento nacional de curta duração.

O Decreto-Lei $\mathrm{n}^{\circ} 21.240 / 32$ tinha por princípio o fato do cinema ser "um meio de diversão que o público já não prescinde." (Simis, 1996, p. 94).

Embora a intencionalidade do decreto privilegiasse a produção de curtas educacionais, pois instituiu o recolhimento de uma taxa (conhecida como taxa cinematográfica) que se converteria para a educação popular através da compra e da produção de filmes educacionais, favoreceu timidamente os produtores nacionais, com a obrigatoriedade de exibição de curtas brasileiros, além da redução de impostos para a importação de negativos virgens e do estabelecimento de uma ínfima cota de tela para o longa nacional (1 título por ano em cada sala de exibição). Mas, ao mesmo tempo, privilegiou o filme estrangeiro ao nacionalizar a censura, e com isso, possibilitar a obtenção do certificado de exibição válido em todo o território

\footnotetext{
${ }^{61}$ A Voz do Carnaval (1933), primeiro musical da Cinédia, quis aproveitar a grande popularidade de Carmem Miranda para alavancar o filme. Foi a estréia da cantora no cinema. Teve uma boa aceitação de público.

${ }^{62}$ Durante a produção do filme, nasce uma importante amizade entre Mauro e o antropólogo Edgard Roquette Pinto, com quem vai trabalhar nos tempos de INCE - Instituto Nacional de Cinema Educacional. O INCE foi o primeiro instituto brasileiro a formular políticas de produção e esse tema será abordado na análise do ciclo do cinema educativo.

${ }^{63}$ A íntegra do Decreto está no Anexo I, p. 85.
} 
nacional $^{64}$. Também diminui as taxas alfandegárias para a entrada de filmes de outros países.

“... não só os filmes que tenham por objetivo intencional divulgar conhecimentos científicos, como aqueles cujo entrecho musical ou figurado se desenvolver em torno de motivos artísticos, tendentes a revelar ao público os grandes aspectos da natureza ou da cultura." (extraído do Decreto-Lei constante no Anexo I, p. 85).

Gonzaga e Santos foram os produtores que mantiveram acesa uma mínima atividade cinematográfica durante a década de 30 .

Em 1941, Moacyr Fenelon, José Carlos Burle, Alinor Azevedo fundam da Companhia Cinematográfica Atlântida, uma produtora com pretensões bem mais modestas que a Cinédia e com características muito particulares. Visava a produção de filmes essencialmente populares e foi construída nos mesmos moldes das companhias norte-americanas com estúdios próprios e elenco de técnicos e artistas de rádio com contrato de trabalho fixo. A pequena reserva de mercado já constituída garantiu o lançamento daqueles que seriam seus maiores astros durante os próximos 15 anos: Oscarito e Grande Otelo.

É somente depois da entrada de Luiz Severiano Ribeiro ${ }^{65}$, dono de uma cadeia de salas exibidoras espalhadas por todo o país, em 1947, que a Atlântida alcança seus maiores sucessos.

Nessa época, Severiano Ribeiro controlava todas as fases do processo (produção, distribuição, exibição), possuindo também um laboratório para processamento dos filmes. É favorecido pela ampliação da reserva de mercado de um para três filmes anuais. Representou mais uma experiência na produção cinematográfica voltada exclusivamente para o mercado e aqui a cópia do modelo americano se traduziu de forma mais completa: produtoras, como Metro e Paramount, também possuíam suas salas exibidoras.

"Esse encontro entre a produção e o comércio exibidor lembra a harmoniosa e nunca repetida conjuntura econômica que reinou no cinema brasileiro entre 1908 e 1911." (Gomes, 2001, p. 74).

A produção era muito rápida e barata, pois havia a necessidade da abordagem de temas e situações contemporâneas. Cenários e figurinos eram mal-feitos e malacabados, mas acabaram sendo incorporados como paródia e "o público que até aí rira do cinema brasileiro, passa a rir com ele." (Souza, 1998, p.108).

Seguindo também os passos dos musicais baratos, a Cinédia realiza O Ébrio (1946), baseado na música homônima de Vicente Celestino e dirigido por sua mulher, Gilda de Abreu. O filme acabou sendo o maior sucesso de público até então. Mas

\footnotetext{
${ }^{64}$ Antes disso, a censura ficava por conta da polícia local. Nem todos os filmes estrangeiros podiam ser exibidos pois algumas autoridades locais, zelosas de suas funções, implicavam com as cenas românticas ou violentas trazidas pelos norte-americanos. A concentração da censura em um único órgão de caráter nacional propiciou uma grande facilidade para os filmes chegarem no interior do

${ }^{65}$ Sevís.
} 
Gonzaga não tem forças para enfrentar o sucesso da Atlântida depois da entrada de Severiano Ribeiro na companhia. Este foi seu último grande sucesso.

O mesmo aconteceu com Carmen Santos. A Brasil Vita faz seu último filme em 1952, um musical baseado na vida do sambista Sinhô,O Rei do Samba.

O modelo de produção da Atlântida foi copiado dos grandes estúdios ${ }^{66}$ e esta é sua maior contradição: conseguia-se a tão sonhada produção industrial em escala, com pontos de exibição garantidos e sem nenhum apuro técnico. Tampouco se cogitava um desenvolvimento tecnológico que minimizasse a dependência de equipamentos e materiais importados.

Nem mesmo se vislumbrava qualquer possibilidade de produção que fugisse da fórmula: músicas (sambas e marchas) + humor (esquetes pontuais) + enredo sem qualquer pretensão.

Temos uma contradição interessante: enquanto Hollywood tinha o controle de tudo (de produção à exibição), buscando uma qualidade visual de excelência e onde cada estúdio se especializou em um tipo de produção com o com objetivo, quase que obsessivo, de dominação de mercado; a Atlântida, que copiou o modelo de produção, a especialização, o controle de todo o processo, desprezou qualquer cuidado técnico em favor de um lucro mais fácil e imediato.

Em relação à qualidade de seus filmes, tanto em relação à temática como em relação às questões estéticas e cuidados de produção, Paulo Emílio declara: "Esse fenômeno [a chanchada] repugnou a críticos e estudiosos." (Gomes, 2001, p. 74).

É claro que a forte afirmação de Paulo Emílio gera atualmente polêmicas e contestações. Mas, esse foi o pensamento corrente na época que influenciou os paulistas na construção da Vera Cruz.

Mas, na época, esses filmes provocaram tantos arrepios em nossas elites intelectuais que se recorreu ao castelhano para encontrar algum tipo de qualificação pejorativa para eles: "chanchada", que traduzido para o português significa "porcaria"67. Verbete já incorporado à nossa língua, chanchada é sinônimo de "filme cinematográfico ou programa televisivo de baixa ou má qualidade." 68

Para não cometer nenhuma injustiça, houve, da parte dos produtores, a tentativa de uma maior elaboração de roteiros e a conseqüente sofisticação de sua produção. Filmes como Nem Sansão nem Dalila (1954) e Matar ou correr (1954), paródias de clássicos hollywoodianos, e O homem do Sputnik (1958), dirigidos por Carlos

\footnotetext{
${ }^{66}$ Inclusive até com a criação do primeiro star system brasileiro que era composto de diversos tipos como os comediantes Oscarito, Grande Otelo, Mesquitinha, Dercy Gonçalves, Ankito e Zé Trindade; os galãs e mocinhas Anselmo Duarte, Cill Farney, Eliana Macedo e Fada Santoro; os eternos vilões José Lewgoy e Wilson Grey e os cantores Emilinha Borba, Linda Batista, Ivon Cury, Sílvio Caldas e Angela Maria. A exceção de Anselmo Duarte, esses tipos ficaram estigmatizados pelas chanchadas.

${ }^{67}$ Sérgio Augusto, em seu livro Esse mundo é um pandeiro, editado pela Companhia das Letras, em 1989, começa seu prefácio recuperando o termo do espanhol. A citação não é textual.

${ }^{68}$ Houaiss, Antonio, Dicionário Houaiss da língua portuguesa,

http://houaiss.uol.com.br/busca.jhtm?verbete=chanchada\&stype $=k \& x=11 \& y=14$, último acesso em 05/02/07.
} 
Manga, segundo Sérgio Augusto, têm lugar em qualquer antologia da comédia cinematográfica nacional. "Manga revelou-se como o mais inteligente diretor de chanchadas e o mais sofisticado dos parodistas." (Augusto, 1989, p. 45).

Mas, no final da década de 50, a chanchada começa a perder o fôlego. As transformações ocorridas no cinema norte-americano ${ }^{69}$, o esgotamento da fórmula musical + humor, sem qualquer iniciativa para buscar novos caminhos, e, principalmente, o surgimento da televisão foram os fatores que enterraram este ciclo.

Em 1962, a Atlântida produz seu último filme, "Os apavorados", de Ismar Porto. De 1941 a 1962 a Atlântida produz 66 filmes.

\section{Ciclo da Vera Cruz}

Enquanto no Rio a produção é garantida pelas chanchadas, São Paulo que havia quebrado junto com a bolsa de Nova lorque por conta da desvalorização do café, começou a mudar seu perfil econômico ainda na década de 30. Manteve uma constante imigração que agora não tinha mais o perfil agricultor. Começava a montar seu importante parque industrial.

Logo após o final da Segunda Guerra, a cidade se transformou no maior pólo econômico do país. Viu o rápido enriquecimento dos imigrantes que apostaram em alternativas como o comércio e a indústria, porém continuava sendo uma cidade rude. A elite de novos ricos acreditava que estava na hora de começarem a se impor como força produtora de cultura. Várias iniciativas de mecenas como Francisco Matarazzo Sobrinho (Cicillo), Franco Zampari, Yolanda Penteado, Ramos de Azevedo, Altino Arantes, Assis Chateaubriand e Freitas Valle, tinham por objetivo projetar a capital paulista como um rico pólo de produção cultural e acabar com o preconceito que a cidade sofria.

Eles acreditavam que o sonho de transformar o cinema em uma indústria voltada a um mercado pagante ainda não havia se realizado e a busca pela excelência técnica também não tinha se concretizado. A experiência carioca foi ignorada pois eles consideraram a produção das chanchadas um fato irrelevante. Quando Paulo Emílio disse que a chanchada provocava a repugnância de críticos, podemos incluir nessa categoria os mecenas de São Paulo, que mantinham a idéia de construir a grande indústria cinematográfica brasileira, nos mesmos moldes norte-americanos ${ }^{70}$.

A partir de 1948, Franco Zampari, próspero industrial de origem italiana, funda o TBC - Teatro Brasileiro de Comédia. Em princípio, o espaço deveria servir a grupos amadores. Percebendo a viabilidade econômica do empreendimento, Zampari organizou a maior companhia de teatro tida no Brasil até então. Com atores,

\footnotetext{
${ }^{69}$ Abordarei adiante quando analisar o ciclo da Vera Cruz, mas basicamente o modelo de produção norte-americano entra em colapso a partir do final da Segunda Guerra.

${ }^{70}$ Esta era uma idéia que estava sendo acalentada há muitos anos, desde os tempos de riqueza cafeeira. Muitas tentativas foram feitas, mas não lograram êxito. No interior do estado, em Campinas e Americana, fazendeiros construíram estúdios e chegaram a montar uma infra-estrutura de produtoras auto-suficientes. Porém não avaliaram a dificuldade de conseguir o retorno financeiro ou caíram nas mas mãos de aventureiros e golpistas. Assim, não suportaram os custos da empreitada.
} 
escritores, cenógrafos e outros técnicos contratados em caráter permanente, o TBC foi a referência artística da década.

Pensar em uma companhia cinematográfica com os mesmos princípios foi o passo seguinte. A Companhia Cinematográfica Vera Cruz foi saudada como finalmente a empresa que proporcionará ao país sua definitiva entrada no circuito do cinema.

Alberto Cavalcanti, o único cineasta brasileiro a ter uma carreira reconhecida no exterior (Inglaterra e França), onde produziu e dirigiu filmes consagrados, foi contratado para ser o produtor executivo da companhia. Trouxe consigo um verdadeiro exército de técnicos europeus para garantir a qualidade técnica e impôs um ritmo de produção frenético: filmes sendo produzidos ao mesmo tempo, em escala industrial, gerando despesas que só poderiam ser recuperadas a longo prazo. Os orçamentos não mediram esforços para que se conseguisse a excelência na qualidade do material captado e editado. Qualidade que poderia ser comparada às produções estrangeiras ${ }^{71}$. Com isso, a companhia vai se endividando.

É sabido que a Vera Cruz produziu 18 longas-metragens em seus primeiros três anos de existência, de 1950 a 1953. Chamou a atenção com a produção do filme "O Cangaceiro" (de Lima Barreto, 1953), que conquistou dois prêmios internacionais (Palma de Ouro no Festival de Cannes de 1953 como "Melhor Filme de Aventura" e "Menção Honrosa à Trilha Sonora" no mesmo festival). Foi o filme brasileiro de maior número de espectadores até aquele momento e teve exibição mundial garantida por um contrato de distribuição com a Columbia Pictures.

Mesmo assim, foi à bancarrota por não conseguir recuperar nas bilheterias o alto custo que a empresa tinha com seu ritmo intenso de produção e com os contratos de distribuição extremamente desfavoráveis que foram assinados.

"O fator principal que levou à derrocada da Vera Cruz, por exemplo, foi o fato dela ter pensado a produção, mas não ter previsto mecanismos de circulação comercial de seus filmes. Esse procedimento não foi exclusivo da Vera Cruz, mas também de seus opositores, como os independentes dos anos 50 e posteriormente o Cinema Novo, pelo menos até a fundação da Difilm." (Bernardet, 2004, p. 61).

Com as mesmas idéias, mas com investimentos menores e tombos iguais, as produtoras Maristela e Multifilmes seguiram pela mesma trilha.

Uma ressalva deve ser feita: é importante relacionar os casos da Vera Cruz e das chanchadas aos acontecimentos contemporâneos tanto nos Estados Unidos como na Europa. A má administração de recursos, da parte da Vera Cruz, e o esgotamento da chanchada são os principais fatores do encerramento destes ciclos. Porém, o modelo de produção parcialmente copiado das grandes companhias como Warner Bros., RKO Radio Pictures e 20th Century Fox, que controlavam a produção com estúdios e equipamentos próprios e a distribuição e exibição, com suas salas de cinema espalhadas pelo mundo, também falia. As restrições européias à importação

\footnotetext{
${ }^{71}$ E mais uma vez, a comparação com o padrão técnico norte-americano se faz presente. E, ao contrário da Atlântida, o pensamento reinante na Vera Cruz não admitia restrições orçamentárias que baixassem a qualidade de suas produções.
} 
de filmes americanos estavam cada vez mais intensas ${ }^{72}$, constantes greves de técnicos de Hollywood, alta inflação nos Estados Unidos, surgimento da televisão são fatores que vão colocando paulatinamente a indústria norte-americana em crise. Os filmes ficavam cada vez mais caros. O resultado é o declínio do número de espectadores internos de 90 milhões em 1948 para menos de 50 milhões dez anos mais tarde ${ }^{73}$. Para aumentar a crise, a indústria sofre, em 1948, dois grandes golpes: por força do congresso norte-americano é aprovada uma lei que obriga as companhias a se desfazerem de suas salas de cinema e, também, a diminuir a quantidade de filmes alugados em bloco pelos exibidores ${ }^{74}$. O segundo golpe é a instauração do Comitê de Investigação de Atividades Anti-Americanas (época conhecida como macarthismo) que leva aos tribunais centenas de artistas e técnicos de sua indústria, acusados de manterem ligações com o Partido Comunista. A conseqüência imediata é a desaceleração da produção norte-americana.

A radical mudança de modelo de produção se dá no início da década de 50 e influencia todas as outras cinematografias. Saem de cenas as empresas com seus grandes estúdios e equipes fixas. O modelo seguido a partir de então fica conhecido como package-unit e consiste na contratação de artistas e técnicos por tempo determinado (pela empreitada), coordenados por um produtor que loca serviços e espaços por tempo determinado em função das necessidades do roteiro e das possibilidades orçamentárias. Os riscos de investimentos em um filme ficam restritos a este filme e são assumidos pelo produtor. A empresa cinematográfica com sua grande estrutura passa a ser uma prestadora de serviços ou uma empresa coprodutora.

A concepção de produção cinematográfica mudava e o Brasil insistiu em um modelo historicamente fadado ao fracasso com a construção de estruturas megalomaníacas até o início da década de 60.

O papel do produtor também mudou: ele não era mais o dono do estúdio. Ele era o dono do filme.

No Brasil ainda estamos buscando compreender melhor essa função. É somente no ciclo da retomada, analisado adiante, que o produtor começa a se estabelecer seguindo um modelo praticado no exterior desde a década de 50. Ainda passaríamos por diversas experiências antes de chegarmos a esse modelo.

\footnotetext{
${ }^{72}$ Na França, o CNC - Centre National de la Cinematographie - é fundado em 1946, com o objetivo principal de defender seu cinema e de manter sua identidade artística e cultural. Todos os países da Europa seguem pela mesma direção. As leis de proteção tornam-se muito mais rígidas com cotas de tela que chegam a até 1 por 1 (para cada filme estrangeiro exibido, um filme nacional tem que ser também exibido). Fundos de produção são criados e mantidos através de porcentagens sobre impostos pagos.

${ }_{73} \mathrm{http}: / /$ www.chambel.net, acesso em 03/11/2006.

74 Tanto os exibidores brasileiros como os norte-americanos tinham a mesma prática: para ter determinado filme de determinado estúdio, eles deveriam alugar um lote imenso com cópias de filmes sem nenhum interesse garantindo aos distribuidores o escoamento de toda a produção de Hollywood. Com a restrição a um lote de, no máximo, 5 filmes, a política externa norte-americana passou a ser muito mais agressiva para dar conta da pouca oferta e do encarecimento imediato de seus filmes.
} 


\section{Ciclo do cinema educativo}

Vamos voltar um pouco no tempo para analisar a evolução da interferência do Estado na produção de cinema que fica mais intensa a partir da década de 60. Mas, historicamente, essa influência começa a se constituir a partir do ciclo do cinema educativo.

Ainda na década de 20, o cinema e a imprensa eram os meios de comunicação de massa implantados no país. Vivíamos em clima ufanista e nosso projeto político era a construção da nação do futuro. Deveríamos acabar com o analfabetismo e introduzir conceitos éticos e civilizados para que o país não sucumbisse ao atraso. Reformar o ensino através do cinema educativo era uma bandeira defendida pelos políticos e intelectuais da época.

Influenciados por ideais socialistas, os projetos que tramitavam no Congresso nessa época traziam embutidas as ideologias que se agregavam em torno de um nacionalismo muito forte. A revolução de 30 , que depôs Washington Luiz e alçou Vargas ao poder, teve um forte apelo nacionalista. E com o discurso da construção de um país pujante através da educação massiva, Vargas instaura uma ditadura de 15 anos de duração.

Em 32, já tínhamos uma lei de proteção à produção de filmes e à sua exibição ${ }^{75}$, mas, não podemos esquecer que as principais justificativas de sua criação focavam a educação massiva ${ }^{76}$.

Em conseqüência, o governo Vargas cria, em ,1936 o INCE (Instituto Nacional de Cinema Educativo), dirigido por Roquete Pinto tendo em Humberto Mauro o seu mais direto colaborador.

O decreto que criou o INCE determinou que sua função era a de "produzir e editar filmes educativos populares (standard, $35 \mathrm{~mm}$ ) e escolares (substandard, 16mm). Parágrafo único: Para desempenhar sua finalidade, o Instituto manterá uma filmoteca; divulgará os filmes de sua propriedade, cedendo-os por empréstimo ou por troca às instituições culturais e de ensino, oficiais e particulares, nacionais e estrangeiras". ${ }^{77}$

A experiência do mercado de documentários deram a Mauro a qualificação para a produção e direção ininterrupta de filmes, durante as próximas três décadas. Entre 1936 e 1966, o INCE, sob o comando do cineasta, foi o responsável pela realização de 357 filmes.

No final da década de 30, o Estado Novo, etapa de recrudescimento da ditadura Vargas, cria o DIP - Departamento de Imprensa e Propaganda, que será o setor da ditadura responsável pela produção dos cine-jornais de propaganda governamental,

\footnotetext{
${ }^{75}$ Decreto-Lei $\mathrm{n}^{0}$ 21.240/32 - Ver Anexo I - p. 85

${ }^{76}$ Lembrando que a principal motivação para a criação do Decreto-Lei $n^{\circ} 21.240 / 32$ foi o desejo de utilização de um meio de comunicação de massa como instrumento de alfabetização e de representação das manifestações culturais. O cinema era o meio que mais se adequava a essa idéia, por ser, na década de 20, o mais popular dos meios.

${ }^{77}$ Ver Anexo I - p. 85
} 
utilizando intensamente a reserva de mercado de curtas nacionais antes do filme estrangeiro, assegurada pelo Decreto-Lei.

Aqui retomamos a experiência dos "cavadores" das décadas anteriores. Mais do que manter um ritmo constante de produção, foram esses produtores que, num primeiro momento, ocuparam as telas garantidas pela lei com seus cine-jornais e documentários encomendados. Propiciaram, também, a formação e qualificação de técnicos parcialmente absorvidos pelas produções do INCE e do DIP.

Já nos departamentos governamentais, o papel do produtor se resumiu a ser o organizador de equipes, cronogramas e eventos. O trabalho serviu a um projeto político com objetivo específico. E a produção foi organizada para esse fim.

Terminada a era Vargas, ventos democráticos trouxeram de volta as organizações classistas. O ritmo de produção dos organismos estatais diminuiu e fomos, aos poucos, deixando de ocupar as telas. Os governos posteriores afrouxaram a fiscalização e, novamente tivemos os espaços de exibição fechados.

As discussões sobre um projeto cinematográfico para o país voltaram à tona. Como vimos, a Europa do pós-Guerra implantou projetos cinematográficos através da criação de institutos que controlavam produção e exibição. O cinema norteamericano passava por profundas transformações. Alberto Cavalcanti, já desligado da Vera Cruz, apresentou, em 1953, um projeto para a criação de um instituo de cinema que regulamentasse a produção e a exibição, inspirado no CNC francês. Este foi um projeto que tramitou por vários anos no Congresso Nacional. Provocou polêmicas pois nem todos os cineastas, como Adhemar Gonzaga, uma liderança ainda expressiva, acreditavam que uma intervenção governamental tão intensa, seria necessária para alavancar nossa indústria. Ficamos divididos entre a livre iniciativa, aclamada durante o confuso governo de Juscelino Kubitschek e a intervenção estatal, defendida no tumultuado governo de João Goulart.

Somente em 1966, com uma ditadura militar instaurada no país, o INC - Instituto Nacional de Cinema - é criado e ele absorve o INCE $^{78}$. E finalmente um governo impõe ao país sua política cinematográfica.

Quando o INC foi extinto em 1976, suas atribuições passaram para a Embrafilme, que também comandou a política do cinema educacional até sua extinção.

A partir de 1990, a produção de filmes e programas educativos passa para a Fundação Roquette Pinto (Rede das Tv's Educativas criada durante o período militar) e, atualmente, se resume ao atual Projeto Escola ${ }^{79}$.

\section{Ciclo do Cinema Novo}

Em meados da década de 50, começam a surgir manifestações de recusa ao projeto da Atlântida e da Vera Cruz. Comandados por Nelson Pereira dos Santos e Alex Vianny, jovens cineastas, influenciados pelo cinema europeu, propõem a construção de um novo cinema; o chamado "cinema de autor" que leva a câmera para fora dos estúdios, filma o povo nas ruas, decreta uma câmera com mais liberdade para filmar

\footnotetext{
${ }^{78}$ Ver anexo II, P. 88.

${ }^{79}$ Fonte: http://www.observatorio.unesco.org.br/colaborativa/node/1813 , acessado em 05-12-2006.
} 
o que está em sua volta ${ }^{80}$. Decreta, também, que a função do produtor seja exclusivamente técnica; um produtor que dê condição ao autor (diretor) de expressar sua mais livre forma de pensar. O produtor desempenhará funções na captação de recursos e na organização de equipes, serviços e materiais, sem, no entanto, manifestar qualquer tipo de ingerência que signifique o tolhimento da liberdade criativa e artística, comandada exclusivamente pelo diretor. Ao produtor cabe a tarefa de ser um facilitador para tornar viável o caminho de realização de uma obra.

A manifestação artística através do seu cinema se impõe com a força suficiente para contrapor qualquer ideal de construção de indústria. Não dá para descolar essa crença do momento histórico em que vivíamos. Estávamos no auge da guerra-fria que colocava o capitalismo contra o socialismo.

Glauber Rocha acreditava que a produção de cultura deveria ser financiada pela burguesia nacional, sem quaisquer ingerências, tanto de capitais externos como de posições mercadológicas. A colocação do filme no mercado tornou-se secundária. A manifestação artístico-cultural estava colocada como um bem tão necessário como a alimentação, a saúde e a educação. Portanto, pregava-se a necessidade dos governos constituídos assumirem o controle e os custos dessas ações.

Nessa época, os cineastas não construíram nenhuma relação com distribuidores e com o mercado.

Isso explica o papel coadjuvante relegado ao produtor nesse período: o técnico a serviço da construção de uma obra.

Alex Viany produz e dirige Agulha no palheiro (1953) enquanto Nelson Pereira dos Santos, Rio 40 graus (1955). Estes são os filmes que inauguram, no Rio de Janeiro, o cinema novo. São produzidos com recursos próprios, utilizam atores amadores saídos dos próprios locais onde foram filmados que contracenam com atores profissionais. São feitos com luz do dia e o número de filmagens em cenários internos é pequeno. Nada é feito em estúdio. E mal conseguem ser vistos.

A mesma coisa acontece com um grupo baiano formado por Trigueirinho Neto que realiza Bahia de todos os santos (1959-60), Roberto Pires, Redenção (1959) e Glauber Rocha, Barravento (1961).

Em São Paulo, Roberto Santos dirige O grande momento (1958), produzido por Nelson Pereira dos Santos. Porém a situação em São Paulo é diferente. Ainda durante a era Vera Cruz, foram criadas leis de âmbito estadual e municipal, que viabilizaram as produções de grupos independentes. Mesmo com o fracasso da Vera Cruz, essas leis continuaram a vigorar e possibilitaram a produção do filme de Roberto Santos.

A lei municipal adotava mecanismos de prêmios porcentuais de 15 a 25\% sobre a renda de bilheteria e a lei estadual possibilitava uma linha de crédito com juros

${ }^{80} \mathrm{O}$ desenvolvimento tecnológico experimentado pelos europeus faz com que as câmeras fiquem mais compactas e mais leves. Tirar a câmera do tripé para colocá-la no ombro do operador é uma facilidade promovida pela indústria que contribui para o surgimento de várias correntes cinematográficas. Entre elas, o Cinema Novo. 
subsidiados através do Banco do Estado de São Paulo (na época, um banco estatal).

"Convém lembrar que não se trata de auxílio ao cinema nacional, mas de operação bancária como outra qualquer. Se o Banco do Estado de São Paulo realiza esta operação, torna-se evidente a viabilidade de outros estabelecimentos agirem da mesma forma, incrementando a indústria cinematográfica." (apud Ramos, 1983, p. $20)^{81}$.

Os filmes O Sobrado (1956) e Osso, amor e papagaios (1957), dos independentes Walter George Dürst e Carlos Alberto de Souza Barros / César Mêmolo, foram filmes que se beneficiaram desses recursos.

Nessa mesma época, Anselmo Duarte produziu e dirigiu o filme $O$ pagador de promessas (1962). Trouxe a Palma de Ouro de Melhor Filme do Festival de Cannes. Isso não foi suficiente para abrir as salas de exibição aos filmes brasileiros.

Deus e o diabo na terra do sol (1964) ${ }^{82}$, que por sua vez, também em Cannes, colocou Glauber Rocha na condição do mais importante cineasta brasileiro, também não traz nenhuma possibilidade de público para sua exibição.

Os cafajestes (1962) e Os fuzis (de 1964), ambos de Ruy Guerra, Vidas secas (de Nelson Pereira dos Santos, 1963), Garrincha, a alegria do povo (1962) e O padre e a moça (1964), de Joaquim Pedro de Andrade, são exemplos da vitalidade com que se ergue essa nova geração e são exemplos também das fracassadas tentativas de mostrarem seus filmes ao público. Foram filmes produzidos pelos próprios cineastas, ou em associação com Luiz Carlos Barreto ${ }^{83}$, com recursos próprios ou cotizados entre a equipe, ou ainda através de pequenos empréstimos; ou seja, de uma forma romanticamente aventureira.

Críticos de cinema da época consideraram que o público brasileiro não estava preparado para se ver nas telas de forma tão árida ou tão hermética. E aqui vem o discurso sobre a aridez (pessoas e lugares feios e sujos) e o hermetismo dos filmes cinemanovistas na voz de seus críticos mais ácidos. Continuamos a cobrar um modelo de cinema com a mesma "qualidade" do norte-americano. Os funcionários de Serrador, os jornalistas da Cinearte, os críticos do cinema novo se repetem. E continuamos com o mercado exibidor fechado.

\footnotetext{
${ }^{81}$ Artigo publicado na revista Visão, de 25/10/57.

${ }^{82}$ Segundo longa metragem dirigido por Glauber Rocha, o filme estreou no Festival de Cannes em 1964. Ironicamente, no mesmo período que o filme era exibido na França, acontecia no Brasil o golpe de estado que instaurou uma ditadura militar que duraria mais de 20 anos. Um filme fadado ao isolamento por falta de salas de exibição também ficou fadado à censura militar que a ditadura impôs ao país.

${ }^{83}$ É necessário fazer um destaque para a atuação de Luiz Carlos Barreto, como o maior produtor dessa época. Daqui pra frente, suas idéias influenciarão as políticas governamentais que serão implantadas. Ele foi jornalista da revista O Cruzeiro, teve uma bem sucedida experiência como coroteirista do filme $O$ Assalto ao trem pagador (de Roberto Farias, 1961) e, ao se aproximar dos cineastas cinemanovistas, viabilizou a produção da maioria dos filmes feitos até então. Com eles, fundou a Difilm, com importante papel quando a discussão sobre o papel do mercado exibidor volta a ser fundamental, e com eles se desentende também em função da interferência do produtor que visa o mercado na criação do filme.
} 
Glauber Rocha representa a voz dos cineastas cinemanovistas e rebate as críticas:

"A chanchada é o câncer conformista do subdesenvolvimento. A Vera Cruz, o apanágio da megalomania. O cinema novo é a síntese criadora do cinema brasileiro popular internacional".(Rocha, 1981, p. 321).

depoimento de Paulo Emílio, mentor intelectual de toda a primeira geração do Cinema Novo, no Congresso Nacional, é esclarecedor ${ }^{84}$.

"Houve até em determinado tempo uma frase célebre: o Brasil não produz filmes como não produz cerejas: questão de clima. Impossível existir cinema no Brasil. As diferentes tentativas de criação do Instituto Nacional do Cinema - essa inicial de Alberto Cavalcanti, uma outra em seguida, formulada por uma Comissão Nacional de Cinema, convocada, ao tempo do governo Kubitschek..., tiveram sempre o mesmo destino: desinteresse, paralisação. Falou-se muito em sabotagem. Falou-se muito em interesses estrangeiros visando sabotar o desenvolvimento do cinema brasileiro. Convenci-me, desde logo, de que, no fundo, projetávamos na força dos estrangeiros a nossa própria fraqueza. Não havia na realidade sabotagem, nem corrupção, para evitar que a matéria fosse adiante. Fundamentalmente as coisas não iam adiante por causa de uma mentalidade importadora que reinava em todas as nossas elites, inclusive parlamentares e políticas." (Gomes apud Ramos, 1983, p. 33-34).

Independente do modelo de produção adotado, seja norte-americano, europeu ou aventureiro, o fato é que não conseguíamos ter ações que possibilitassem o uso do cinema como uma forma de expressão da nossa cultura, como esclarece Paulo Emílio. A cota de tela que nos protegia ainda era garantida pela mesma legislação vigente durante o Estado Novo, e agora não surtia muito efeito ${ }^{85}$.

O debate de idéias é intenso e dois grupos polarizam as discussões. Universalistas, representados por cineastas independentes como Walter Hugo Khouri e Flávio Tambellini que acreditavam na livre iniciativa, no aprimoramento técnico e estético e, sobretudo, na abordagem de temas mais existencialistas; e os nacionalistas, representados pelo grupo cinemanovista. Não cabe aqui esmiuçar as diferenças mais sutis de cada grupo, mas o ponto de comunhão: sem o Estado o cinema não se viabiliza.

Enquanto isso, João Goulart é deposto por militares que assumem o poder. O novo governo articula a formação de uma entidade que estabeleça um projeto para a indústria cinematográfica nacional, mas que não provoque grandes estragos nas relações entre os países alinhados com a nascente ditadura. É criado, 1966, o INC -

\footnotetext{
${ }^{84}$ Paulo Emílio Salles Gomes foi convidado a depor em CPI instaurada em setembro de 1964 para investigar as atividades cinematográficas que aconteciam no Brasil.

${ }^{85}$ As cotas de tela, ou seja, o número de dias durante o ano que as salas são obrigadas a passar filmes brasileiros cresce paulatinamente desde o Estado Novo. Mas a cada mudança, a pressão de distribuidores e exibidores para acabar com a cota de tela é muito grande. Para agravar esse quadro, a falta de fiscalização, que não permite o cumprimento da lei, e os fabulosos lucros que o cinema americano obtinha no Brasil são fatores importantes que inibem a exibição brasileira. O lucro se dava por conta de uma altíssima inflação que mantinha a taxa oficial de conversão do dólar quase cinco vezes menor que a variação do dólar no mercado livre. Isso possibilitava aos americanos uma remessa de lucros muito favorável.
} 
Instituo Nacional de Cinema ${ }^{86}$, com a nomeação de Flávio Tambellini para presidente do instituto. Isso representou uma derrota, de alguma forma já prevista, para o grupo nacionalista.

Ao INC coube a centralização de todas as decisões relativas à atividade cinematográfica. Suas fontes de receita viriam através do recolhimento de taxas percentuais sobre a venda de ingressos de filmes estrangeiros em salas de cinema; do imposto sobre a remessa de lucros que os distribuidores recolhiam, de uma taxa denominada "contribuição para o desenvolvimento da indústria nacional", imposta a todos os filmes destinados à exibição comercial em cinema e televisão (com exceção dos filmes publicitários); e mais eventuais dotações orçamentárias do Governo Federal. Ficou com a incumbência de regulamentar a produção nacional de filmes, com poder de decisão para repassar dinheiro aos produtores em forma de prêmio adicional de renda, com base no desempenho dos filmes no circuito exibidor no financiamento ou apoio às produções, catalogar todas as empresas produtoras, distribuidoras e exibidoras do país, fiscalizar suas atividades, garantir o cumprimento das leis vigentes, dar continuidade aos projetos educativos comandados pelo INCE, estabelecer normas para acordos de co-produção e cuidar de sua fiscalização.

Enquanto isso, os cineastas ${ }^{87}$ Glauber Rocha, Nelson Pereira dos Santos, Roberto Farias, Luiz Carlos Barreto, Cacá Diegues, Joaquim Pedro de Andrade, Paulo César Saraceni, Leon Hirszman, Roberto Santos, Riva Farias e Rex Endsley fundam, em 1965, a Difilm - Distribuidora de Filmes Ltda. -, que consegue, através de empréstimos levantados junto ao Banco Nacional, fazer a distribuição regionalizada de filmes garantindo assim um relativo sucesso dos filmes produzidos nessa época e que jamais chegariam às telas através das grandes distribuidoras existentes na época ${ }^{88}$.

A Difilm iniciou a prática do adiantamento (ou avanço) de distribuição aos produtores para o financiamento dos filmes. A sociedade se desfez em 1968 por desentendimentos do grupo e foi Luiz Carlos Barreto quem assumiu a compra das cotas da empresa. A Difilm desempenhou um papel importante garantindo a produção e distribuição de filmes realizados por cineastas como Joaquim Pedro, Leon Hirszman e, até mesmo pelo próprio Glauber, que se posicionaram francamente contra o golpe militar.

Mesmo que formalmente ela ainda exista como uma empresa distribuidora, atrelada à LC Barreto e à Filmes do Equador (produtoras pertencentes à família Barreto), não teve fôlego para suportar o encarecimento da produção, que mais uma vez o cinema norte-americano promovia. Mas, as idéias de produção e distribuição que

${ }^{86}$ O Decreto-Lei no 43/66 que o criou e sua respectiva regulamentação estão transcritos no Anexo II, p. 88.

${ }_{88}^{87}$ Esse é o principal grupo da primeira geração dos cinemanovistas.

${ }^{88}$ Normalmente as temáticas desses filmes se aproximavam dos ideais marxistas, que não deixava de ser um sério problema pois o golpe militar era a resposta que os Estados Unidos esperavam do Brasil para coibir os ideais socialista-revolucionários que floresciam pela América Latina. Além disso, os exibidores tradicionais, ou seja aqueles já estabelecidos, se, antes da ditadura, não tinham muito interesse na exibição de filmes brasileiros por conta da melhor remuneração que o filme estrangeiro propiciava, depois da ditadura e sem que o INC conseguisse cumprir ainda seu papel fiscalizador, a situação piorou. A Difilm, de determinada forma, conseguiu dar, por um período de tempo, uma resposta a isso. 
circulavam lá serão incorporadas pela Embrafilme, segundo depoimento de Barreto a Helena Salem: "A Difilm era, no nível privado, o que depois foi a Embrafilme". (Salem, 1987, p. 96)

A facilidade da filmagem na rua, livre dos cenários pesados de estúdios, com luz natural e atores não profissionais, determinou um tipo de história a ser contada. Esse tipo de produção limitava a história a ser contada. Filmes como "Macunaíma" (1969), por exemplo, jamais poderiam ser feitos se a produção ficasse limitada a esse modelo. O que antes era um recurso, tornara-se uma armadilha. Os cinemanovistas souberam reconhecer isso e buscaram o apoio governamental para a realização de seus filmes.

Em termos numéricos, o apoio do INC a filmes do grupo universalista ${ }^{89}$ foi um pouco maior e se deu através do empréstimo de equipamentos, na viabilização dos prêmios e financiamentos e na fiscalização das leis de cotas de tela, que ficou mais eficiente no final da década.

Mas os nacionalistas também conseguiram filmar com o apoio do instituto e obtiveram seus sucessos.

"Dois filmes de cineastas do Cinema Novo, por sua vez, destacam-se dessa massa de filmes produzidos com intermediação do INC, por conseguirem aliar uma proposta cultural em redefinição a uma grande penetração junto ao público: 'Macunaíma' (1969), de Joaquim Pedro de Andrade, realizado com recursos da Condor Filmes, e (..) 'Como era gostoso o meu francês' [de Nelson Pereira dos Santos, 1972], uma das maiores rendas de bilheteria de 1972." (Ramos, 1983, p. $62)$.

O período se destacou pela polarização entre duas vertentes: a expressão cultural e artística através da produção de obras cinematográficas versus a produção de filmes em escala industrial para o fortalecimento de uma indústria. Em seu curto período de vida, o INC viveu a contradição de apoiar as duas vertentes. Era um aparelho a serviço de uma ditadura militar, a serviço de um projeto de industrialização, e, ao mesmo tempo, apoiava filmes que, de forma alegórica ou figurada, criticaram o regime e usavam o cinema como forma de expressão cultural e artística.

Com o Al V, o projeto político da ditadura militar, que é a modernização do parque industrial e o fortalecimento da classe média brasileira, foi implantado. O "milagre econômico"90 sustentava esse projeto porque acreditava que uma indústria forte pagaria os empréstimos conseguidos no exterior.

\footnotetext{
${ }^{89}$ Khouri, com suas temáticas existencialistas e produção bem cuidada, teve excelente aceitação de público, principalmente com "Noite vazia", filme de 1964. O cineasta foi desprezado pelos cinemanovistas que lhe deram a alcunha de "Bergman brasileiro", para tachá-lo de alienado.

${ }^{90}$ Expressão usada para definir a política que promoveu um imenso endividamento do país através de empréstimos junto a instituições financeiras e governos estrangeiros. Essa medida fazia parte da estratégia que o regime de exceção usou para fortalecer a classe média brasileira e, assim, conseguir seu apoio. Garrastazu Medici (1970-1974) foi um dos presidentes mais populares em sua época, pois promoveu um desenvolvimento econômico artificial muito rapidamente. Pôde, assim, impor um dos mais violentos governos que tivemos em nossa história, cujo alto preço viemos pagar a partir do governo do presidente José Sarney (1985-1990) que trouxe para o Brasil um estado de hiperinflação, economia indexada e moratória.
} 
O INC, com sua estrutura formada por conselhos que tinham entre seus membros realizadores cinematográficos não conseguiu responder aos anseios da ditadura. $O$ projeto da Embrafilme foi criado para implantar um modelo industrial, com forte controle governamental.

Além disso, já no final da década de 60, o cinema passou por mais uma transformação tecnológica que encareceu novamente sua produção: o cinema colorido, até então era um evento esporádico, passou a ser uma constante. Outras inovações tornaram as câmeras mais pesadas. A gravação de som direto, por exemplo, passou a exigir câmeras blimpadas. A configuração da equipe de produção de um filme se diferencia pois há a exigência de um maior número de técnicos capazes de manipular essa nova tecnologia.

Coloco o encerramento do ciclo do Cinema Novo junto com a extinção do INC, pois foi com a consolidação do projeto encabeçado pela Embrafilme (a partir de 1969), que houve uma evidente mudança nos caminhos da produção cinematográfica.

Voltou-se a procurar o diálogo com o público através de filmes que conseguissem competir no mercado exibidor. Voltou-se a buscar a equiparação da produção brasileira com a produção norte-americana. E assim nasceu um projeto político com o objetivo de controlar todas as etapas da realização cinematográfica: produção, distribuição e exibição.

\section{Ciclo da Embrafilme}

"O cinema brasileiro saiu de uma fase em que a multiplicidade de realizações experimentais e contestatórias provocou uma retração do público. Agora há uma franca procura de narrativas de fácil aceitação popular. O mais importante é que as diversas tendências de produção mantenham-se ligadas com a capacidade de absorção do público, reconheçam que as platéias cinematográficas se mostram dia a dia mais exigentes quanto ao nível técnico e espetacular e se organizem para atender tais requisitos." (Mattos Jr. apud Ramos, 1983, p. 96) ${ }^{91}$.

É dessa forma que Carlos Guimarães justifica a mudança de rumo que a política cinematográfica sofrerá a partir do início da década de 70 , a partir do governo Médici.

A Embrafilme ${ }^{92}$ foi criada enquanto o INC ainda operava.

Os cinemanovistas lutavam para transformar o INC num fomentador de cultura.

O projeto da Embrafilme veio para mudar esse enfoque. A posse de Guimarães, alinhado com as idéias de modernização do parque industrial cinematográfico, trazem ao INC um novo caráter.

\footnotetext{
${ }^{91}$ Trecho de artigo de Carlos Guimarães de Matos Jr. (então Secretário de Planejamento do INC e, logo depois, presidente), publicado na Filme e Cultura $n^{\circ} 21$, jul./ago.72, Rio de Janeiro, INC.

${ }_{92}$ A Embrafilme foi constituída pelo Decreto-Lei $n^{\circ}$ 862, de 12 de setembro de 1969. Anexo 3, pág. 97.
} 
Enquanto a Embrafilme canalizava recursos através do imposto retido nas remessas de lucros obtidos pela exploração do filme estrangeiro no mercado nacional, o INC criava sistema de multas para descumprimento da obrigatoriedade de exibição, implantando um sistema mecanizado de controle de ingressos.

As quotas de exibição passam a se pautar por estudos econômicos e de mercado.

A polarização entre as duas vertentes, por mais reducionistas que possam parecer, é um fato que amplifica as tensões vividas naquele período. Geraram conflitos, mas trouxeram certezas que deram respaldo à política pró-Embrafilme. Filmes como Pindorama (de Arnaldo Jabor ${ }^{93}, 1971$ ), apoiado por recursos materiais e financeiros do INC e Aladim e a lâmpada maravilhosa, com Renato Aragão, (de J. B. Tanko, 1973), produzido pela Embrafilme, são exemplos dessa dicotomia. Enquanto o primeiro é um filme difícil de ser entendido e sem nenhuma repercussão de público; o segundo volta-se à comédia popular e é um sucesso instantâneo de público.

Em 1973, cinemanovistas da primeira e da segunda gerações, liderados por Glauber Rocha, assinaram o manifesto "Luz e ação", onde convidaram todos os setores envolvidos na produção cinematográfica a uma mobilização que suscitasse novas idéias e fizesse o cinema brasileiro sair de sua crise. Esse grupo conseguiu convencer os controladores estatais que a continuidade do cinema brasileiro dependia da superação de obstáculos, desde que não fossem desprezados acúmulos e influências trazidos pelo Cinema Novo.

"No início dos anos de 1960, Glauber podia ser polêmico-revolucionário e não soar delirante, pois estava efetivamente a encarar a força produtora de uma nova era no cinema brasileiro; em 1973, é o tom antiépico da reflexão do crítico [Paulo Emílio Salles Gomes, Cinema: trajetória no subdesenvolvimento] em nome da continuidade da cinematografia que alcança como nenhum outro texto do início dos anos 1970, um enorme impacto na cultura." (Xavier, 2004, p. 11-12).

Filmes como Pindorama não cabiam no projeto de construção da indústria cinematográfica. E tanto Arnaldo Jabor como os organismos estatais perceberam isso com nitidez. Seu próximo filme (Toda nudez será castigada, 1974) será produzido pela Embrafilme e mostrará a confluência dos projetos cinemanovistas e governistas $^{94}$.

Em, 1975, é lançada, pelo governo, a PNC - Política Nacional da Cultura atendendo a reivindicações feitas durante o I Congresso da Indústria Cinematográfica (1972). O INC é extinto, a Embrafilme altera suas atribuições, passando a ser uma financiadora de filmes, absorvendo parte dos recursos que eram do INC como as taxas percentuais recolhidas sobre a venda do ingresso do cinema, contribuição em forma de taxas por cada título estrangeiro exibido em território nacional, participação nos lucros de filmes financiados por ela e percentual do imposto sobre a remessa de lucros de filmes estrangeiros pago pelas distribuidoras.

\footnotetext{
93 Jabor é considerado um cineasta da segunda geração do Cinema Novo.

${ }^{94}$ Através da filmagem da polêmica peça de Nelson Rodrigues, Jabor obtém prêmios no Festival de Cinema de Berlim e reconhecimento popular. Continuará sua carreira bem-sucedida junto ao público com filmes de alto teor erótico como Eu te amo (1980) e Eu sei que vou te amar (1984).
} 
Para cuidar das questões da distribuição de filmes, é fundada a Embrafilme Distribuidora que, com o passar do tempo, absorve para o seu orçamento o dinheiro destinado ao Prêmio Adicional de Bilheteria e acaba por extingui-lo.

Para a elaboração de normas regulamentadoras para a atividade cinematográfica tendo o poder de fiscalizar, autuar e punir infratores, o Concine - Conselho Nacional do Cinema ${ }^{95}$ é instituído.

E aqui voltamos ao papel do produtor, que agora se personifica na figura de Luiz Carlos Barreto. Ele foi o produtor que realizou o maior número de títulos dessa época, além de ter conseguido as maiores bilheterias. Mas sua atuação de produtor fica mais centrada na parte executiva e no gerenciamento da realização do que propriamente na acepção mais ampla do sentido que tem essa função. O dinheiro, financiamento e riscos ficam para a Embrafilme Produtora e Distribuidora. E é ela, portanto, quem decide qual filme que será feito e como ele será feito. Não seria exagero admitir que o Estado assume a função de produtor.

Roberto Farias, diretor geral da Embrafilme de 1974 a 1979, resume o funcionamento da empresa em mensagem enviada à lista de discussão Cinemabrasil ${ }^{96}$ :

“... já cansei de explicar que a Embrafilme era primeira credora dos recursos aplicados, e o produtor não recebia um centavo referente ao valor aplicado pela Embrafilme, enquanto ela não se ressarcisse do investimento. Que a receita do produtor enquanto isso limitava-se ao percentual equivalente ao seu próprio investimento; que para fazer outro filme com a empresa era necessário que o produtor tivesse pago no mínimo 60\% dos recursos empregados pela Embrafilme no filme dele. Que a Embrafilme ainda ficava com a distribuição, que Ihe rendia uma boa quantia; que a Embrafilme adiantava 30\% do orçamento como distribuidora e se associava com mais 30\%, ficando por conta do produtor realizar os outros $40 \%$. Que aquele sistema era mais defensável do ponto de vista do [uso do] dinheiro público do que o atual sistema; que o ideal teria sido a Embrafilme em vez de ter sido fechada, tivesse se transformado num banco de fomento, com as mesmas características e conhecimento do setor, como nunca houve; que a Embrafilme foi fechada pelos seus acertos, não pelos seus erros; que a Embrafilme financiou inúmeros primeiros filmes de estreantes; que não havia protecionismo; que os orçamentos eram glosados e [era] estudada sua compatibilidade com o filme que o cineasta pretendia fazer; mas que sendo uma empresa, a Embrafilme não primava por encher o saco do produtor com exigências descabíveis e burocracia desnecessária; que procurava funcionar mais parecida com um banco de fomento especializado, que, como já disse era sua verdadeira vocação".

Embora Farias conteste o papel de produtor que a Embrafilme desempenha e coloca o órgão em um papel técnico de agente financiador, em outra mensagem à lista

\footnotetext{
${ }^{95}$ Os decretos de criação e de regulamentação desses órgãos estão no Anexo III, p. 97.

96 A mensagem foi enviada à lista de discussão do site http://www.cinemabrasil.org.br (lista de discussão: cinemabrasil@cinemabrasil.org.br, em resposta às constantes acusações de favorecimento econômico a apadrinhados e todo o tipo de bagunça, desde a organização interna até o controle das produções que apoiava e/ou distribuía constantemente imputadas à Embrafilme).
} 
Cinemabrasil, ele conta um caso interessante, onde reconhece que o órgão tinha um papel bem mais amplo ${ }^{97}$ :

“... me lembro de um roteiro do Glauber, o da 'Idade da Terra'. Só quem sabia valorizar currículos seria capaz de financiar o filme, como nós, na Embrafilme daquele tempo. Não era um roteiro, eram anotações sem qualquer preocupação de ser julgado por elas. Divergimos, sim, ele queria um orçamento enorme que eu não podia conceder porque ultrapassava de muito os valores habituais, algo como três ou quatro vezes. Gustavo [Dahl] sugeriu a ele que apresentasse um orçamento dentro dos parâmetros. A contragosto, ele apresentou e eu assinei o financiamento. À tarde, do mesmo dia, ele apresentou um pedido de reajuste segundo o orçamento original. Genial, não? O importante é que o filme foi realizado."

É somente a partir de 1976 que o cinema brasileiro alcança seus melhores resultados numéricos.

De 1976 a 1986, o cinema brasileiro lança, em média, 80 filmes por ano no circuito exibidor. A Embrafilme Distribuidora é responsável pela grande maioria dos títulos lançados (Almeida \& Butcher, 2003, p. 54).

No mesmo período, a média de público para filmes brasileiros foi de 50 milhões de espectadores por ano e correspondeu a $30 \%$ do total do público que foi ao cinema (Almeida \& Butcher, 2003, p. 54).

Foi sua época áurea. Dona Flor e seus dois maridos (1976, Bruno Barreto), filme distribuído pela Embrafilme, é considerado, até hoje, o filme de maior público do cinema brasileiro. Estima-se que, só em salas de cinema, ele tenha sido visto por mais de 10 milhões de brasileiros ${ }^{98}$.

Outros títulos que contribuíram para o sucesso da produtora e da distribuidora com excelente repercussão de público e prêmios internacionais são: Toda nudez será castigada (1973, Arnaldo Jabor), Lição de amor (1974, Eduardo Escorel), A dama do lotação (1978, Neville D’Almeida), Bye bye Brazil (1979, Cacá Diegues), Gaijin, os caminhos da liberdade (1980, Tizuka Yamasaki), Pixote (1981, Hector Babenco $)^{99}$, Eles não usam black-tie (1981, Leon Hirszman), Eu te amo (1981, Arnaldo Jabor), Memórias do cárcere (1984, Nelson Pereira dos Santos), só para citar os filmes que mais público tiveram.

\footnotetext{
${ }^{97}$ A mensagem foi encaminhada à lista Cinemabrasil em 28-11-2006 e tinha o objetivo de comparar o modelo de produção praticado pelo INC / Embrafilme com o que praticamos hoje, defendendo o modelo estatal. O trecho destacado exemplifica que as escolhas da Embrafilme eram muito diferentes das praticadas hoje. Mas, o exemplo nos mostra que a estatal se pautava pelo currículo do diretor. Ou seja, ela decidia sim quem filmaria. Não se pode afirmar que fosse por apadrinhamento. Talvez fosse realmente por mérito, pois Glauber tinha o status de mais influente cineasta brasileiro da época, mas, não se pode negar o papel de produtor exercido por ela.

${ }_{98}$ Segundo o boletim Filme B, o filme de Barreto vendeu 10.735 .305 ingressos na época de seu lançamento (Maria do Rosário Caetano, As maiores bilheterias do cinema nacional, in: Revista de Cinema, no. $24-$ abr/2002).

${ }_{99}$ Recebeu uma indicação ao Globo de Ouro, na categoria de Melhor Filme Estrangeiro e ganhou o Leopardo de Prata, no Festival de Locarno.
} 
Já na década de 80, a Embrafilme centralizava todas as iniciativas de produção e exibição de filmes brasileiros existentes no país. A dependência do projeto estatal foi total. Todas as outras tentativas de constituição de produção independente desse modelo, como veremos adiante, sucumbiram.

Os produtores da Boca do Lixo ${ }^{100}$ foram os mais contundentes críticos desse modelo. Imputaram à Embrafilme Produtora e à Embrafilme Distribuidora o fardo de serem as responsáveis por matar qualquer iniciativa de produção que fosse independente da estatal.

Com o fim da ditadura militar e durante o governo de José Sarney, a partir de 1986, começamos a sofrer as conseqüências nefastas do "milagre econômico". O Brasil passou por uma crise econômica sem precedentes, com inflação de 100\% ao mês, economia indexada ao dólar e à beira da falência. A crise das empresas estatais é inerente ao momento. Elas já não possuíam os mesmos recursos orçamentários que dispunham na década anterior. Salas de cinema são paulatinamente fechadas e a venda de ingresso cai consideravelmente. Duzentos milhões de ingressos de cinema foram vendidos em 1979. Em 1990, noventa e cinco milhões. E fica nesse patamar durante boa parte da década de 90 (Almeida \& Butcher, 2003, p. 54).

A escassez de recursos, cada vez mais minguantes, impediu que as empresas estatais atendessem a uma crescente solicitação ${ }^{101}$.

Os últimos anos da década foram melancólicos.

Em 1990, com a eleição de Fernando Collor, Embrafilme, produtora e distribuidora, e Concine foram extintos sem que políticas para a área cinematográfica fossem repensadas. Começamos a era do mercado eleito como o regulador de produção e da livre iniciativa de todos os setores industriais, cinema incluso. As importações de produtos industrializados ficam liberadas sem restrições.

A conseqüência imediata foi a parada total da produção de filmes.

De 1991 a 1993, nenhum longa metragem brasileiro de ficção foi produzido. (Almeida e Butcher, 2003, p. 24).

Em 1992 apenas três títulos brasileiros que ainda estavam inéditos foram lançados no mercado exibidor. (Almeida \& Butcher, 2003, p. 26).

No final da década de 80 , a média de público do filme brasileiro chegava a vinte milhões de espectadores por ano. Em 1992, o número de espectadores foi de 32 mil. (Almeida e Butcher, 2003, p. 13).

\footnotetext{
${ }^{100}$ Ver p. 63 , ciclo das pornochanchadas.

${ }^{101}$ Além dos cineastas estabelecidos, faculdades de cinema são abertas na década de 70 , lançando no mercado jovens cineastas com a vontade de realizar seus próprios filmes. Só que a produção está centralizada em um único projeto. Contra as estatais, crescem a insatisfação e acusações de apadrinhamento e de malversação do dinheiro público.
} 


\section{Ciclo do Cinema Marginal}

No final da década de 1960, na contramão dos movimentos encabeçados pelos cineastas do Cinema Novo e pelos chamados universalistas, um grupo de jovens artistas, começou a produção de uma série de filmes sem qualquer preocupação com modelos de produção e o mercado intrínseco a eles.

“... esta proposta radical do final da década que explodiu no momento mais duro do regime militar e se eclipsou, como movimento de grupo, por asfixia econômica e censura policial logo antes do balanço de Paulo Emílio [Cinema: trajetória no subdesenvolvimento]." (Xavier, 2004, p. 11).

O marco inaugural do udigrudi, como ficou conhecido o movimento do ciclo marginal ou o cinema do lixo, é o filme $A$ margem (1967), de Ozualdo Candeias. Seu maior representante foi Rogério Sganzerla com O Bandido da luz vermelha (1968), que, segundo Inácio Araújo, em ensaio sobre o filme, teve uma grande repercussão de público na época de seu lançamento. (apud Labaki, 1998, p. 72). Mas isto foi exceção. A regra é que se os filmes não foram embargados pela censura, foram repudiados pelos distribuidores e seus circuitos exibidores.

O que caracteriza o ciclo é exatamente a falta de um modelo de produção. Sem orçamento, sem produtor e realizados às custas dos favores de amigos, a atitude de seus realizadores era de se manter à margem de qualquer mecanismo da produção mercadológica.

Mais alinhado com o movimento tropicalista, parodiou westerns e outros gêneros estrangeiros. Criou polêmicas espetaculares com o grupo cinemanovista e sofreu perseguições da direita e da esquerda. Ou seja, fez de tudo para não dar certo.

O comum entre os filmes dessa tendência é a temática em torno da marginalidade que freqüentemente abordava e, principalmente, sua precária produção.

Ao contrário do Cinema Novo, que neste momento, buscava dialogar com os organismos estatais para continuar produzindo diante das dificuldades tecnológicas e mercadológicas, não teve fôlego e durou cerca de três anos.

"O Lixo teve tempo, antes de perfazer sua vocação suicida, de produzir um timbre humano único no cinema nacional. Isolada na clandestinidade, essa última corrente de rebeldia cinematográfica compõe de certa forma um gráfico do desespero juvenil do último qüinqüênio." (Gomes, 2001, p. 105).

Quando Paulo Emílio se refere à vocação suicida da geração udigrudi , acredito que ele vai além da discussão sobre as posições políticas e estéticas defendidas pelo movimento. A história que está sendo analisada reafirma a fala do pesquisador: enquanto a nossa cinematografia não firmar em um terreno propício, ela não se constitui como produção ${ }^{102}$. O cinema somente poderá ter uma constância em sua produção quando o país puder garantir um mercado consumidor suficientemente forte para financiar essa produção. Nesse sentido, o ciclo do cinema marginal foi exemplar.

\footnotetext{
102 Isso também nos remete à reflexão de Paulo Emílio sobre a possibilidade do Brasil cultivar cerejas
} (p. 53). 


\section{Ciclo das pornochanchadas ${ }^{103}$}

Movimento cinematográfico que ficou concentrado na cidade de São Paulo, ou melhor, em uma região central da cidade, ou especificando melhor ainda: em uma rua da cidade de São Paulo - a Rua do Triunfo ${ }^{104}$.

Os primeiros filmes produzidos lá são de 1970 . Teve seu auge entre os anos de $75 \mathrm{a}$ 80 e seu declínio começou no início da década de 80.

Teve vários trunfos a seu favor: escritórios de distribuidores e exibidores estavam estabelecidos nessa região e provocava a afluência de técnicos e gente de cinema pelos bares da Rua do Triunfo e adjacências. O INC conseguiu finalmente normatizar as cotas de telas e montar um sistema mais eficiente de fiscalização nas salas de cinema. Distribuidores e exibidores voltam a se interessar pela produção (setenta anos depois). Mais tarde, a atuação do Concine, melhorando as condições de fiscalização da Lei de Obrigatoriedade, favoreceu ainda mais a aproximação de distribuidores e exibidores com os produtores.

Copiando o modelo de produção norte-americano praticado desde a década de 50, o package-unit, o cinema desse ciclo teve a vantagem de trabalhar em consonância com o tripé produção / distribuição / exibição.

O cinema da Boca do Lixo ${ }^{105}$ produzia filmes de baixíssimo orçamento, rápidos de serem feitos, voltados para o público da região, assumidamente sem cuidados técnicos porque o tempo de produção era o parâmetro que contava, sem preocupações com a elaboração de enredos sofisticados e voltados ao público freqüentador da região ${ }^{106}$. Daí vem a imediata associação com as chanchadas da Atlântida. Mas, os cantores populares com suas marchinhas de carnaval foram substituídos por cenas de nudez e sexo. Está constituído nosso segundo star system: Vera Fischer, Helena Ramos, Aldine Müller e David Cardoso ${ }^{107}$.

"Captadores de recursos, administradores, investidores, negociadores, entre outras habilidades (com alguns adjetivos não muito elogiosos) [os produtores] foram os responsáveis pela circulação do capital e do crédito, pelo investimento, em meios de produção - câmeras, materiais de iluminação, maquinárias e até estúdios, e, também, por problemas trabalhistas. Esse papel do produtor, uma escala da Boca

\footnotetext{
${ }^{103}$ No Rio de Janeiro, comédias eróticas também são produzidas e, algumas delas, com boa repercussão nacional. Foram feitas de forma independente, com recursos próprios, e a maioria recuperou os investimentos com o Prêmio Adicional de Bilheteria. Mas não chegaram a se constituir enquanto um ciclo de produção.

${ }^{104}$ Além de concentrar gente de cinema, a região que é próxima da Estação da Luz e da antiga Estação Rodoviária, é conhecida por seu alto índice de prostituição. Daí vem o nome Boca do Lixo.

${ }^{105}$ Os filmes produzidos na Boca foram taxados genericamente de pornochanchadas. Se ficarmos restritos ao sentido que a palavra "pornochanchada" traduz (comédias eróticas), corre-se o risco de reduzir a produção da Boca. Nem todos os filmes eram comédias e o teor erótico nem sempre era obrigatório. O que é comum ao ciclo é a forma de produção. Utilizarei eventualmente o termo "pornochanchada" com esta ressalva.

${ }^{106}$ O público das pornochanchadas era constituído, em sua grande maioria, por pessoas de baixa renda. Por isso, o circuito exibidor a ele destinado estava concentrado nos cinemas do centro e de periferia.

${ }^{107}$ À medida que as pornochanchadas foram se fortalecendo, esse star system teve uma importância significativa para a produção dos filmes. Esses são nomes que traziam consigo a garantia de público.
} 
do Lixo, revestia de um verniz industrial o processo produtivo ali praticado". (Abreu, 2006, p. 51).

Carlos Reichenbach, que transitou entre o cinema marginal e o cinema da boca em seu início de carreira, descreve também o perfil dos produtores e investidores desse ciclo:

"69 e 70 foram os anos mais prolíficos da produção paulista. Ao contrário do Rio, o cineasta de São Paulo, não buscou o seu investidor no meio de suas relações com os grandes banqueiros, os poderosos industriais, ou os mecenas eventuais. Seus financistas geralmente eram caçados entre fazendeiros, lascivos proprietários de postos de gasolina, amigos que possuíam amigos ricos, parentes mais abastados (normalmente um tio mais liberal), comerciantes e até ganhadores da loteca". (Reichembach, 1981, p. 83).

Tanto na descrição de Reichenbach como na de Abreu, o perfil insinuado do produtor traz o estigma do "cavador", do "descolador". E foi realmente dessa forma que as primeiras pornochanchadas foram feitas. Os primeiros produtores usaram de suas economias (ou perspicácia) para fazer os primeiros filmes.

Com o sucesso, conseguiram pagar seus investimentos e partir para o próximo até que distribuidores e exibidores passaram a investir também. Antonio Galante ${ }^{108}$, em depoimento a Nuno Cesar Abreu ${ }^{109}$, confirma que $50 \%$ do orçamento total do filme era bancado pelos exibidores. A condição para o fechamento do negócio era o prazo dado pelo exibidor para que se pudesse cumprir a Lei de Obrigatoriedade. Em casos mais raros, os percentuais investidos foram maiores. Assim, a partir de 75, todos os cinemas de rua ${ }^{110}$ das zonas centrais e bairros menos nobres de São Paulo passavam os filmes produzidos pela Boca.

O avanço de distribuição, praticado pela primeira vez no Brasil pelos cineastas do Cinema Novo com a Difilm utilizando-se de empréstimos bancários, foi copiado pelo cinema da Boca agora sem a intermediação de instituições financeiras e diretamente com o distribuidor que tinha o capital para esse investimento.

O auge da Boca aconteceu quando seus filmes se beneficiaram de forma mais sistêmica do Prêmio Adicional de Bilheteria. Com boa performance de público, os prêmios passaram a ser significativos. O número de filmes produzidos cresceu consideravelmente e seu mercado exibidor se ampliou. Surgiu uma "hierarquização" com os produtores de primeira linha como Anibal Massaini, que começaram a melhorar a qualidade técnica e artística de seus filmes, e os de segunda, como o

\footnotetext{
${ }^{108}$ Antonio Galante ficou conhecido como o Midas da Rua do Triunfo. Foi um dos maiores produtores dessa época e foi, também, o mais dependente de distribuidoras e exibidoras. Outros produtores bancavam os custos de sua produção e só se associavam aos distribuidores e exibidores na fase de lançamento e exibição do filme. Com isso, a Boca até teve sua fase "autoral" onde alguns cineastas, como o próprio Reichenbach se destacou, mas o grosso da produção trabalha com filmes de encomenda.

${ }^{109}$ Depoimento que consta no livro: Boca do lixo - Cinema e classes populares. Campinas: Editora Unicamp, 2006.

${ }^{110} \mathrm{Na}$ década de 70 e até meados da década de 80 , as salas de cinema eram salas de espetáculos com disposição semelhantes a teatros. A denominação "cinema de rua" começou a ser usada no Brasil a partir da chegada dos cinemas multiplex (abordada no ciclo da retomada).
} 
próprio Galante e Alfredo Palácios que melhoraram suas instalações físicas, aumentaram o número de filmes em produção, mas continuaram com o mesmo processo de produção: rapidez e restrições orçamentárias.

A entrada em operação da Embrafilme Distribuidora, que absorveu o dinheiro do Prêmio Adicional de Bilheteria, foi o primeiro fator que desestruturou a indústria implantada pela Boca. Por ter tido um efeito mais demorado para ser sentido, durante um determinado período de tempo teve fôlego para produzir filmes de grande sucesso de público como Elas são do baralho (Sílvio de Abreu, 1977), Mulher objeto (Silvio de Abreu,1981) e O bem dotado (José Miziara, 1978).

O grande golpe sofrido pelo cinema da Boca e que, segundo seus produtores, foi determinante para o seu declínio, foi o fechamento das pequenas distribuidoras nacionais devido à política agressiva de distribuição imposta pela Embrafilme Distribuidora $^{111}$.

Aníbal Massaini, em depoimento a Nuno Cesar Abreu, relata:

"Eu acho que essa política que a Embrafilme desenvolveu de certa maneira acabou desestruturando as empresas produtoras e distribuidoras. [...] Pra gente pleitear a distribuição de um filme com algum nível, a gente tinha que entrar em competição com a Embrafilme, com recursos próprios, numa época em que a inflação já estava presente. Ela promovia a finalização de um filme, com os valores entrando como valores nominais numa conta corrente, para serem ressarcidos meses depois sem correção. Para uma empresa privada é absolutamente impossível. Vamos falar de duas Embrafilmes: tem uma que vem como órgão de fomento, no tempo da 13 de maio, $4^{\circ}$ andar, onde o papel dela era financiar a produção: 200 mil 'reais', 1 ano de carência, 2 anos de prazo, assinava 36 promissórias e ia embora. Aí, quando ela começa a entrar com distribuição, co-produção, esta história muda." (Abreu, 2006, p. 190-191).

Além de todos os problemas já relatados, ainda surge um agravante: a indústria pornográfica mundial cresce em ritmo acelerado. Filmes com cenas de sexo explícito são produzidos em larga escala. As grandes distribuidoras internacionais, que são as únicas em operação no país além da Embrafilme Distribuidora, lançam os títulos estrangeiros, que se transformam em um negócio mais vantajoso para exibidores e distribuidores que o investimento na produção de similares nacionais. A Boca, ao mesmo tempo, não consegue equacionar seus problemas de modo a se reposicionar no mercado.

"A produção da Rua do Triunfo se conscientizou de que a explosão do lixo cinematográfico de 'sexo explícito' é profundamente predadora e estourou na sua cabeça. Na projeção de alguns anos, se continuar como está, vai decretar sua extinção. Por isso, vital e urgente a criação de circuito restrito para a modalidade. Isso abrirá nos circuitos populares o espaço para o filme médio, a produção $B$ popular, bem acabada e de fácil veiculação. Se a Rua do Triunfo soçobrar, contudo,

\footnotetext{
${ }^{111}$ Temos que considerar também que na década de 80 o Brasil encontra sua pior crise econômica e institucional. A Embrafilme sozinha não pode ser responsabilizada pelo fim do cinema da Boca. A falência de todo o cinema brasileiro está anunciada pela própria falência do país.
} 
arrastará no naufrágio também o melhor cinema que se pratica ou se tenta praticar no Brasil." (Fraga, 1984, p. 112).

Massaini responsabilizou o Estado pela falência das pornochanchadas e Ody Fraga, por sua vez, à invasão da indústria pornográfica internacional. Estamos vendo que a falência se deu por uma série de fatores que incluem as duas vertentes.

Quando chegamos aqui, no final da década de 80, encontramos um fato absolutamente inédito. Até aqui, os ciclos que abordei se sobrepuseram uns aos outros: enquanto um modelo falia, outro grupo se articulava e tentava caminhar em outra direção. A Boca olhava para si sem encontrar saída para sua crise. A mesma coisa acontecia com a Embrafilme. Em 1990 a produção de filmes brasileiros de longa metragem acabou. Os filmes produzidos na Boca, os produzidos pela Embrafilme e quaisquer outros filmes que estivessem sendo ruminados neste momento deixaram de existir ${ }^{112}$.

Somente a partir de 1992 é que o cinema volta a se reorganizar. O ciclo analisado a seguir é o que acontece em nossa atual produção. Já foi chamado de "ciclo do renascimento", mas a polêmica em torno da morte do cinema brasileiro já encontrou fóruns mais apropriados, então vamos adotar a nomenclatura mais usual: "ciclo da retomada".

\section{Ciclo da Retomada}

Em 1992, o impeachment de Fernando Collor possibilita a formulação de uma nova política para o setor cinematográfico que é obrigado a buscar outros modelos de produção.

A política econômica vigente desde 1990 é a neoliberal que tem o mercado como referencial para a produção dos bens industrializados. Dentro dessa política, o risco da produção é do produtor, uma vez que o neoliberalismo tira do Estado qualquer possibilidade de financiamento ou de subsídio. É assim que a indústria cinematográfica teria que reorganizar sua produção, que se encontrava paralisada.

Com essa filosofia, o mercado brasileiro foi aberto para a livre importação. Seu impacto sobre a indústria foi imediato e provocou conseqüências como um elevado índice de desemprego e um crescente empobrecimento da classe média brasileira. Os efeitos provocados por essas medidas foram no mercado exibidor, que, de 1990 a 1995 , viu o fechamento de $1 / 3$ de suas salas de cinema. (Almeida \& Butcher, 2003, p.54) $)^{113}$.

As salas restantes ficaram ocupadas com os filmes estrangeiros.

A reorganização da indústria cinematográfica brasileira através da livre iniciativa privada era inviável para um cinema que foi fortemente subsidiado durante os últimos vinte anos, tanto em sua produção como em sua exibição. Ademais, por

\footnotetext{
${ }^{112}$ Existe um fato isolado, mas que ficou marcado como "o símbolo" desse momento: João Batista de Andrade, em pré-produção de uma ficção que recriava os últimos dias de vida do jornalista Vladimir Herzog, abortou o projeto com a posse de Fernando Collor. Este filme nunca mais será feito.

${ }^{113} \mathrm{Em} \mathrm{1990,} \mathrm{o} \mathrm{número} \mathrm{de} \mathrm{salas} \mathrm{no} \mathrm{Brasil} \mathrm{era} \mathrm{1.488.} \mathrm{Em} \mathrm{1995,} \mathrm{1.033.} \mathrm{(Almeida} \mathrm{\&} \mathrm{Butcher,} \mathrm{2003,}$ p.54).
} 
exigir um alto investimento e não ter garantias de retorno financeiro o torna um negócio de altíssimo risco.

Para que a produção voltasse a existir, era necessária a intervenção do Estado e ela foi conseguida através de políticas de incentivos fiscais que a reativaram.

A nova política implantada e vigente até os dias de hoje baseia-se na renúncia fiscal. Trata-se de um mecanismo onde o Estado deixa de arrecadar uma determinada porcentagem de impostos em favor da produção de filmes. Essa porcentagem é decidida anualmente conforme as dotações orçamentárias estipuladas pelos Ministérios do Planejamento e da Fazenda.

O repasse do dinheiro do imposto se dá pelo contribuinte e não pelo governo. O produtor, credenciado pelo Ministério da Cultura, apresenta seu projeto a uma empresa ou a uma pessoa que tem imposto de renda a pagar. O investidor pode, então, destinar parte de seu imposto a pagar ao patrocínio de uma produção cinematográfica.

Coube ao Ministério da Cultura, através da Secretaria do Audiovisual ${ }^{114}$ controlar o montante autorizado a ser captado. Uma vez que o teto é atingido, os projetos subseqüentes ficam sem a aprovação de captação até o ano seguinte quando nova dotação será feita. Atualmente esta tarefa é executada pela Ancine ${ }^{115}$.

Mas, a aprovação do projeto não garante ao produtor o engajamento do contribuinte. O produtor terá que encontrar investidores que estejam dispostos a financiar a produção de filmes com parte do dinheiro que usaria para pagar seus impostos e que queiram associar seus nomes e / ou suas marcas a um determinado projeto.

Com essa filosofia, duas leis foram sancionadas:

A Lei Rouanet, Lei $n^{\circ} 8.313 / 91^{116}$, conhecida também como "lei do mecenato", abrange produtos culturais como peças de teatro, produção de livros, espetáculos de música e dança e também o cinema ${ }^{117}$.

E a Lei do Audiovisual, Lei $\mathrm{n}^{0} 8.685 / 93^{118}$, que permite ao investidor adquirir cotas do filme que serão comercializadas no mercado de capitais, em ativos previstos em lei e

\footnotetext{
${ }^{114}$ SAV - Secretaria do Audiovisual - subordinada ao Ministério da Cultura.

${ }^{115}$ Diferentemente da era Embrafilme-Concine, controladoras dos processos de produção e exibição, a Ancine é uma agência reguladora, com o papel de intermediar, regular e fiscalizar as relações entre a produção das indústrias cinematográficas e videofonográficas com seu mercado consumidor.

${ }_{116}$ Anexo V, p. 106.

${ }^{117}$ Essa lei foi herdada de Collor que tentou salvar seu mandato compondo ministérios e secretarias de "notáveis" para conseguir o apoio de intelectuais e formadores de opinião. Como o Ministério da Cultura havia sido extinto pelo mesmo presidente transformando-o em uma Secretaria de Governo, coube a Sérgio Paulo Rouanet a reestruturação do órgão e a implantação de políticas culturais para o país. Daí saiu a Lei Rouanet, que se baseou na mesma concepção da antiga Lei Sarney, primeira lei brasileira que usava os preceitos da renúncia fiscal para a produção cultural, revogada por Collor com graves denúncias de possibilitar lavagem de dinheiro e corrupção indiscriminada. Para coibir qualquer tentativa de fraude ou de irregularidade, regras e limites foram colocados, tanto no corpo da lei como em sua regulamentação e nas diversas portarias e decretos que vieram posteriormente.
} 
autorizados pela Comissão de Valores Mobiliários - CVM, nos mesmos moldes das empresas de capital aberto (sociedades anônimas) que negociam suas ações nas bolsas de valores. Esses incentivos possibilitam a produção de obras audiovisuais ${ }^{119}$ brasileiras de produção independente e a realização de projetos nas áreas de exibição, distribuição e infra- estrutura técnica.

A tabela a seguir faz a diferenciação atualizada entre as duas leis de modo comparativo para investimentos em longas metragens ${ }^{120}$.

\section{LEI ROUANET}

\begin{tabular}{|c|c|}
\hline investidor & $\begin{array}{l}\text { pessoa física - até } 6 \% \text { do imposto } \\
\text { devido } \\
\text { pessoa jurídica - até } 4 \% \text { do } \\
\text { imposto devido }\end{array}$ \\
\hline $\begin{array}{l}\text { limite de } \\
\text { investi - } \\
\text { mentos } \\
\text { por projeto }\end{array}$ & $\begin{array}{l}\text { - quando o incentivo se dá apenas } \\
\text { através dessa lei - não há limite } \\
\text { quando o incentivo se através } \\
\text { desta lei combinada com outras } \\
\text { de renúncia fiscal - R\$ } \\
3.000 .000,00\end{array}$ \\
\hline \multirow{2}{*}{$\begin{array}{l}\text { deduções } \\
\text { p.j. }\end{array}$} & Até $40 \%$ do valor investido \\
\hline & $\begin{array}{l}\text { O investimento poderá ser deduzido } \\
\text { como despesa operacional }\end{array}$ \\
\hline \multirow{2}{*}{$\begin{array}{l}\text { contrapra- } \\
\text { tidas } \\
\text { exigidas } \\
\text { do } \\
\text { produtor }\end{array}$} & $\begin{array}{l}\text { - quando o incentivo se dá apenas } \\
\text { através dessa lei - não há }\end{array}$ \\
\hline & $\begin{array}{l}\text { quando o incentivo se através } \\
\text { desta lei combinada com outras } \\
\text { de renúncia fiscal - } 5 \% \text { do } \\
\text { orçamento total do filme }\end{array}$ \\
\hline \multirow{2}{*}{$\begin{array}{l}\text { órgão } \\
\text { respon- } \\
\text { sável }\end{array}$} & $\begin{array}{l}\text { - quando o incentivo se dá apenas } \\
\text { através dessa lei - SAV }\end{array}$ \\
\hline & $\begin{array}{l}\text { quando o incentivo se através } \\
\text { desta lei combinada com outras } \\
\text { de renúncia fiscal - ANCINE }\end{array}$ \\
\hline
\end{tabular}

LEI DO AUDIOVISUAL - ART. $1^{\circ}$

- pessoa física - até $6 \%$ do imposto devido

- pessoa jurídica - até $3 \%$ do imposto devido

$\mathrm{R} \$ 3.000 .000,00$

$100 \%$ do valor investido

O investimento poderá ser deduzido como despesa operacional

$5 \%$ do orçamento total do filme

ANCINE

Tanto a Lei do Audiovisual, através de seu Art. $1^{\circ}$, como a Lei Rouanet possuem o mesmo princípio: qualquer contribuinte brasileiro (pessoa física ou jurídica sem distinção) que quiser destinar parte do dinheiro que usaria para pagar seu imposto de renda no financiamento de uma produção audiovisual, poderá fazê-lo mediante as regras mostradas na tabela comparativa.

\footnotetext{
118 Anexo IV, p. 104.

${ }^{119}$ A lei define obra audiovisual como o produto da fixação ou transmissão de imagens, com ou sem som, que tenha a finalidade de criar a impressão de movimento, independentemente dos processos de captação, do suporte utilizado inicial ou posteriormente para fixá-las ou transmiti-las, ou dos meios utilizados para sua veiculação, reprodução, transmissão ou difusão. E define a obra de produção independente como aquela produzida por empresa produtora brasileira, detentora majoritária dos direitos patrimoniais sobre a obra que não tenha qualquer associação ou vínculo, direto ou indireto, com empresas de serviços de radiodifusão de sons e imagens ou operadoras de comunicação eletrônica de massa por assinatura.

${ }^{120}$ Fonte: Manual do produtor elaborado pela Ancine,

in: http://www.ancine.gov.br/media/manual produtor.pdf , último acesso: 25-01-2007.
} 
Os mecanismos de captação de recursos através das duas leis de fomento obrigam o produtor a percorrer os departamentos de marketing e de controladoria fiscal de empresas em busca de recursos que financiem a produção.

A expectativa é que o produtor tenha uma boa performance junto às empresas para conseguir captar os valores necessários.

Somente empresas de grande porte têm capacidade de investir quantias significativas uma vez que o limite do investimento é de $4 \%$ do valor que será pago à Recita Federal. Por isso, um único investidor não consegue cobrir um orçamento de produção de um longa metragem.

Apresento abaixo uma simulação hipotética bem grosseira para exemplificar a ordem de grandeza dos valores que estou citando:

Uma empresa que tem um lucro líqüido de dez milhões de reais, pode ser considerada uma empresa de grande porte. Se ela tira desse valor por volta de $30 \%$ para o imposto de renda, ela paga, aproximadamente, 3 milhões à Receita Federal. Desses 3 milhões, ela poderá destinar 4\% a projetos cinematográficos, ou seja, ela poderá destinar, por volta de 120 mil reais ao filme em captação.

Um filme de baixo orçamento custa, aproximadamente, 2 milhões de reais. Ele conseguirá a permissão para a captação de, aproximadamente, 1 milhão e 900 mil reais e precisará ter o apoio de mais 15 empresas do mesmo porte.

Assim, o cinema brasileiro busca em seu produtor um agente com trânsito nos departamentos de marketing e financeiro das grandes empresas.

De 1994 a 1998, a produção em ritmo acelerado volta a encontrar os eternos problemas de distribuição e exibição. Filmes prontos não conseguem entrar em circuito comercial. Nem a fundação da Riofilme ${ }^{121}$ possibilita o escoamento da produção. As empresas que investiram por pretenderem aliar seu nome a um marketing cultural recuam e há um princípio de crise. Algumas medidas governamentais ajudam a contornar o evidente esgotamento desse modelo.

Comento essas ações a seguir:

1) Cota de tela:

Desde 1996, o Ministério da Cultura conseguiu reutilizar a Lei de Obrigatoriedade de Exibição de Filmes Nacionais através das cotas de tela. Ela continuava em vigor, mas tendia ao desuso. Mas, com a atuação da Ancine, a partir de 2002, é que as cotas voltam a ser respeitadas. É importante observar que distribuidores e exibidores

${ }^{121}$ A Riofilme - Distribuidora de Filmes é uma estatal ligada à Prefeitura da Cidade do Rio de Janeiro. Foi fundada a partir de negociações dos cineastas cariocas com seu poder público municipal para amenizar a vacância deixada pela Embrafilme Distribuidora. Logo ela seria procurada pelos produtores de todo o Brasil, mas ela não tem fôlego para o entrar na cadeia de exibição nacional. 
voltam a dialogar com os produtores com a partir da atuação do Ministério da Cultura e da Ancine.

\section{2) Criação da Ancine:}

A Agência Nacional de Cinema foi criada em 2000, vinculada ao Ministério do Desenvolvimento, Indústria e Comércio Exterior com a perspectiva que montaríamos a indústria cinematográfica brasileira dentro da ótica do livre comércio. Subordinada ao MDIC, a dicotomia cinema indústria versus cinema cultura se evidenciou. Esse foi um dos motivos para sua definitiva transferência para o MinC. Desde sua criação, a Ancine assumiu o papel fiscalizador e regulamentador da indústria cinematográfica brasileira.

3) A aproximação do distribuidor e produtor através do Art. $3^{\circ}$ :

Com a cota de tela e com a efetivação do uso Artigo $3^{\circ}$ da Lei do Audiovisual ${ }^{122}$, que concede benefícios fiscais, nos mesmos moldes do Artigo $1^{\circ}$, às empresas ligadas ao mercado audiovisual com sede em outros países e que pagam o imposto de renda sobre sua remessa de lucros, os distribuidores voltaram a se interessar pela produção nacional.

Assim, os distribuidores internacionais, organizadas em torno da MPA-AL ${ }^{123}$ começaram a utilizar a Lei do Audiovisual para fomentar a produção de filmes nacionais.

A tabela a seguir traz um resumo dos dados colhidos no site da MPA-AL ${ }^{124}$ :

\footnotetext{
${ }^{122}$ Diz o Art. $3^{\circ}$ da Lei do Audiovisual: "Os contribuintes do Imposto de Renda incidente nos termos do Art. $13^{\circ}$ do Decreto-Lei $n^{\circ} 1.089$, de 1970 , alterado pelo art. $2^{\circ}$ desta Lei, poderão beneficiar-se de abatimento de $70 \%$ (setenta por cento) do imposto devido, desde que invistam no desenvolvimento de projetos de produção de obras cinematográficas brasileiras de longa metragem de produção independente, e na co-produção de telefilmes e minisséries brasileiros de produção independente e de obras cinematográficas brasileiras de produção independente. (Redação dada pela Lei $n^{\circ} 10.454$, de13.5.2002)".

Diz o Art. $2^{\circ}$ da Lei do Audiovisual que modificou o Art. $13^{\circ}$ do Decreto-Lei $n^{0} 1.089$, de 1970: "As importâncias pagas, creditadas, empregadas, remetidas ou entregues aos produtores, distribuidores ou intermediários no exterior, como rendimentos decorrentes da exploração de obras audiovisuais estrangeiras em todo o território nacional, ou por sua aquisição ou importação a preço fixo, ficam sujeitas ao imposto de $25 \%$ na fonte."

123 A Motion Picture Association - Latin American Regional Office representa as seguintes distribuidoras: Warner, Paramount, $20^{\text {th }}$ Century Fox, Sony-Columbia, Universal e Buena Vista.

${ }^{124}$ http://www.mpaal.org.br/index.html , último acesso em 06/02/2007.
} 


\begin{tabular}{cc} 
ano & $n^{\circ}$ de filmes incentivados através do Art. $3^{\circ}$ \\
\hline 1996 & 3 \\
\hline 1997 & 4 \\
\hline 1998 & 3 \\
\hline 1999 & 4 \\
\hline 2000 & 11 \\
\hline 2001 & 10 \\
\hline 2002 & 4 \\
\hline 2003 & 16 \\
\hline 2004 & 16 \\
\hline 2005 & 15 \\
\hline 2006 & 12 \\
\hline & 24
\end{tabular}

De 1996 a 2000, o número de filmes apoiados pelas distribuidoras é pequeno e uso da Lei do Audiovisual ainda não surte efeitos consideráveis. Mas, três fatos impulsionam os distribuidores na aproximação com os produtores.

São eles:

- Em 2000 (assinalado em azul) a Rede Globo entra no mercado de produção de filmes. Dos 11 filmes apoiados, 3 são diretamente ligados à Globo ("Xuxa popstar", "Auto da compadecida" e "Um anjo trapalhão") e mais 3 tiveram exibição em horário nobre, na semana do Cinema Brasileiro (Bossa Nova, Eu, tu, eles e Villa Lobos - Uma vida de paixão). Nos anos subseqüentes, há sempre um filme co-produzido pela Globo Filmes apoiado por algum distribuidor.

- E em 2001, além da criação da Ancine, a Medida Provisória $n^{0} 2.228-1$, de 6 de setembro de 2001, estabelece os princípios para a Política Nacional do Cinema, cria um Conselho Superior do Cinema e autoriza a criação de Fundos de Financiamento da Indústria Cinematográfica Nacional - FUNCINES.

- A implantação dos sistemas Multiplex (ver abaixo).

4) Começo de operação dos sistemas Multiplex no Brasil:

Enquanto os cinemas de rua estavam sendo fechados ${ }^{125}$, uma nova forma de exibição vai se impondo no mercado brasileiro. A entrada em operação do sistema de exibição Multiplex, a partir de 1997, faz o número de salas de cinema aumentar de 1.077 para 1.647 em 2002 (Almeida \& Butcher, 2003, p. 54) e até 2005, para 1.716 salas (http://www.abraplex.com.br/dados.html\#cotaemp, último acesso em 04/02/2007).

Os sistemas Multiplex operam com conceitos que aliam grande oferta e alta rotatividade de títulos a horários de exibição flexíveis. Para isso, seus complexos possuem de 05 a 18 salas num mesmo endereço, usualmente shoppings centers ou locais que atraem uma grande quantidade de público.

\footnotetext{
${ }^{125}$ Como vimos, o fechamento dos cinemas de rua têm acontecido desde a década de 1980 e essa é uma tendência que se mantém até hoje.
} 
A oferta de títulos tem que ser muito grande e a cota de tela favorece a alta rotatividade. Os números constantes no site da Abraplex mostram que o lançamento de títulos nacionais ultrapassa a cota de tela mínima. Esses números dão pistas de que a cota de tela favorece a oferta de títulos de um Multiplex.

Valmir Fernandes, presidente da Abraplex, em editorial publicado na página principal do site ${ }^{126}$, faz um veemente protesto contra a Lei de Obrigatoriedade, observando que ela em nada ajuda o cinema nacional e é anti-democrática. Porém, o gráfico copiado abaixo, nos mostra que ela não é tão danosa assim ${ }^{127}$.

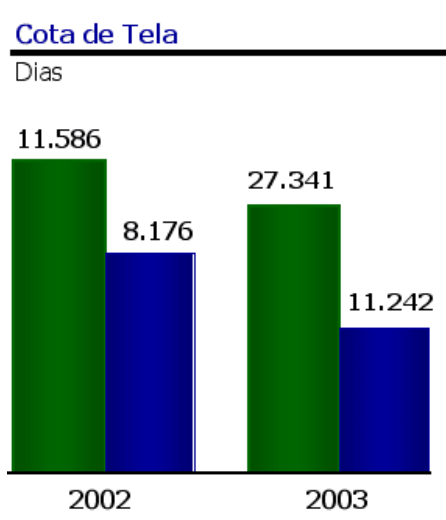

Em 1999, 31 filmes nacionais foram lançados no circuito exibidor. (Almeida \& Butcher, 2003, p.26). A partir desse ano, mesmo com todas as ações descritas, a média de filmes lançados anualmente se mantém na faixa de 30 títulos anuais (Filme B e Abraplex).

A produção do "ciclo da retomada" pode ser resumida da seguinte forma: até o ano de 1998, mesmo com o fechamento contínuo das salas de cinema, é sabido que o volume da produção aumentou por conta dos dados disponibilizados pelas distribuidoras. A Ancine e a Filme B não disponibilizaram o número de filmes prontos ou que esperam seu lançamento, ou que foram lançados em circuitos alternativos ou, ainda, simplesmente não foram lançados.

Mas, os dados disponíveis são muito significativos. A Ancine publicou um relatório $^{128}$, datado de 31/12/2005, que mostra o desenvolvimento de 689 projetos cinematográficos autorizados a captar recursos através das leis de incentivos durante o ano de 2005. Do total, 351 projetos não possuíam valores captados e 50 apresentaram alguns recursos captados, mas não concluíram a captação e 110 estavam prontos. Os outros estavam em fase de finalização ${ }^{129}$.

Os dados das distribuidoras e exibidoras mostram que os produtores nacionais colocam 30 filmes, em média, no mercado exibidor. E essa é uma tendência que se mantém há 5 anos.

\footnotetext{
${ }^{126}$ http://www.abraplex.com.br/index.html, último acesso em 05/02/2007.

127 Gráfico copiado do site http://www.abraplex.com.br/dados.html\#cota, , último acesso em 05/02/2007.

${ }^{128}$ Dados tirados do Relatório de Projetos Ativos , p. $5-6-7$, último acesso ao site em 04/02/2006. http://www.ancine.gov.br/media/Relatorio Projetos Ativos 2005.pdf

${ }^{129}$ É certo que os produtores têm dois anos de prazo para realizar a captação, prorrogáveis em mais dois anos. Os relatórios da Ancine não apontam as datas limites de cada projeto.
} 
Grosso modo, se, em 2005 a Ancine colocou em relatório que 110 filmes estavam prontos em 2005 e foram lançados 30, podemos deduzir que quase 80 filmes ficaram sem exibição nesse ano.

Mesmo que os dados apresentem algumas distorções, eles conseguem mostrar uma realidade que os cineastas da retomada percebem e que Hector Babenco, em depoimento à Lúcia Nagib, expressa de forma sintética:

"Há uma distorção absurda criada no Brasil: todo diretor se transforma em seu próprio produtor, você é obrigado a ser a puta e o cafetão ao mesmo tempo.

[...] O cinema brasileiro atual está nesse tripé: Um roteiro para aprovar na Lei, um captador e o Adhemar de Oliveira ${ }^{130}$ para exibir no Espaço Unibanco de Cinema. Só que o Adhemar não tem condições de dar vazão a todos os filmes. E você faz um produto industrial para passar em quatro salas de cinema?" (Nagib, 2002, p. 81).

\footnotetext{
${ }^{130}$ Adhemar de Oliveira, um exibidor independente que só pôde começar a operar de forma mais eficaz depois do surgimento das duas leis de incentivos fiscais. Ele fez uma bem-sucedida parceria com o Unibanco e revitalizou um cinema de rua de São Paulo, mas já dentro de um conceito de Multiplex. Promoveu uma reforma que transformou uma única sala de exibição em 3 salas menores. Hoje investe na abertura de outros multiplex voltados para filmes diferenciados. É o exibidor que mais lança filmes nacionais.
} 


\section{capítulo 3: O cinema brasileiro atual}

\section{Desafios para o produtor brasileiro de longas metragens}

Quatorze anos após a publicação de leis que possibilitaram a retomada da produção cinematográfica, o momento é de impasse.

Algumas políticas governamentais têm garantido uma média de lançamentos de 30 filmes anuais.

Esse número de filmes tem se mantido constante graças a algumas ações estatais. A mudança de redação no Artigo $3^{\circ}$ é um exemplo que fez as distribuidoras se aproximarem da produção nacional.

Mas, ao que tudo indica, o momento pode ser de estagnação ou de esgotamento do modelo adotado.

Uma recente polêmica envolvendo Luís Carlos Barreto e Toni Ventrui ${ }^{131}$, pode suscitar algumas reflexões sobre a produção de filmes hoje.

Em uma mesma reportagem ${ }^{132}$, Barreto e Venturi expõem seus pontos de vista: 0 primeiro acredita que os recursos estão pulverizados em diversos projetos e cada um deles pega uma cota ínfima que traz dificuldades na produção e na comercialização. Para Barreto, é preferível que as salas de cinema exibam 5 filmes blockbusters brasileiros por ano em vez de termos mais de 50 projetos dividindo os recursos. Isso só enfraquece o cinema brasileiro, segundo o produtor.

Ao contrário, Venturi defende a diversidade e a descentralização como o maior ganho proporcionado por estas leis, além de possibilitar a abertura do mercado de trabalho aos jovens cineastas.

Essa é uma polêmica que destaquei por considerar ser um ponto de partida do desafio que o cinema brasileiro terá de enfrentar a partir de agora.

Pontuando o que está embutido na fala dos cineastas:

- Não há questionamento sobre a interferência do Estado, tanto na produção como na distribuição e exibição. A discordância está no como ele deve interferir. Barreto sugere uma interferência maior quando pede a eleição de cinco grandes projetos para capitalizar os recursos disponíveis.

- Ambos falam da conquista de um mercado inacessível até o momento. Enquanto um acredita que a concentração do público é a melhor saída, o outro acredita que somente a oferta de grande quantidade de títulos é que forçará a entrada do filme brasileiro no mercado exibidor.

\footnotetext{
${ }^{131} \mathrm{Na}$ época, presidente da APACl - Associação Paulista de Cineastas.

${ }^{132}$ Patrícia Villalba em artigo para o jornal O Estado de S. Paulo, 18/12/04: "Ancinav, Fla-Flu do cinema", http://observatorio.ultimosegundo.ig.com.br/artigos. $\operatorname{asp?cod=308ASP006}$
} 
Durante o durante o Seminário "Tendências e Perspectivas do Negócio Audiovisual"133, Carlos Augusto Calil, participante da Mesa que debatia o tema "Diagnóstico do Mercado", fez o contraponto entre essas duas visões expondo o problema de uma outra forma. A produção cinematográfica está fadada à falência, pois a utilização de leis como essas para financiar a produção cinematográfica, gera desperdício sem resolver a questão do financiamento da produção. À medida que os filmes prontos chegam praticamente pagos às telas, sem a necessidade de lucros, o que justifica esse procedimento é o volume de capitais movimentados durante a fase de captação. Está criada uma indústria paralela especializada na feitura de projetos.

O problema levantado por Calil se traduz nos números apresentados. Quantos desses projetos, com captação parcial serão finalizados e conseguirão chegar às telas?

Os dados apontam que tanto a pulverização como a concentração de recursos não resolvem as questões de produção.

E ele também aponta uma questão importante quando fala que os filmes chegam às telas com sua produção paga. Durante o período de 1993 a 2003, a contrapartida para o produtor, exigida por lei, era de $20 \%$, o que significa que $80 \%$ de sua produção estava paga.

A partir de 2003, os itens comercialização e distribuição estão incorporados ao orçamento de produção e a contrapartida é para $5 \%$. Ou seja, o filme chega às telas com $95 \%$ de sua produção e lançamentos pagos.

Continuando a falar da produção, uma outra questão merece um olhar mais atento. Um filme de baixo custo (na pulverização sugerida por Venturi) tem poucas chances de alcançar um número expressivo de espectadores, pois não tem dinheiro para a feitura de muitas cópias dentro do modelo de exibição adotado pelos Multiplex. Isto não interessa a empresas que usam essas leis como meio de marketing cultural. Então, ele precisará de um maior investimento para lançar seu filme com um número de cópias suficientes para atingir um grande público e, conseqüentemente, deixará de ser um filme de baixo custo.

Por outro lado, o produtor de filmes com orçamentos mais altos precisa ter em sua carteira de clientes um "pool" de empresas para poder fechar todo o seu orçamento. Nesse caso, o produtor demora muito na captação dos recursos, e a produção do filme pode levar mais de 2 anos para se concretizar. Isso também não interessa ao investidor.

Um outro desafio para o produtor vem com a entrada das novas tecnologias na produção cinematográfica. A década de 1990 trouxe uma revolução tecnológica sem precedentes na história do entretenimento. A entrada de sistemas digitais de

${ }^{133}$ Seminário promovido pelo Departamento de Cinema, Rádio e TV da ECA - USP, Departamento de Cinema da FAAP, Departamento de Artes da UFSCAR, ABPITV, Pró - Reitoria de Cultura e Extensão da USP, CIBA - CILITEC, MPA e Consulado Geral da França e realizado em São Paulo (Auditório da FAAP) de 15 a 18 de agosto de 2005. 
reprodução de som e imagem possibilitou meios como o DVD e a multiplicação de canais de televisão. Possibilitou que a internet também transmitisse imagens e sons.

Essa é uma tecnologia que hoje traz um conflito para o produtor que não é possível se prever uma solução a curto prazo, pois, ao mesmo tempo em que possibilita o barateamento da produção quando um único padrão de tecnologia é utilizado desde a captação até as cópias digitais; encarece, e muito, quando a opção é o hibridismo entre suportes e entre tecnologias analógicas e digitais.

Além disso, há a questão da exibição digital que vai eliminar os custos das cópias em $35 \mathrm{MM}$. Os cinemas receberão por satélite imagens e sons codificados. Segundo Steve Solot, presidente da MPA-AL, também presente no Seminário "Tendências e perspectivas do negócio audiovisual", os custos dessa transmissão ainda são inviáveis até para a indústria norte-americana. Mas ela será implantada para a exibição de filmes estrangeiros no Brasil e é possível que o acesso dos filmes nacionais às salas de exibição tornem-se mais difíceis ainda.

Por outro lado, a empresa brasileira Rain desenvolveu uma tecnologia de exibição digital com custos mais acessíveis que a tecnologia norte-americana, um bom padrão de qualidade e um modelo de negócios baseado na publicidade que antecede a exibição dos filmes. Ela já opera em mais de 100 salas e se não houver a imposição do modelo norte-americano de exibição, ela poderá se tornar uma alternativa à produção independente.

Mas, a opção pela exibição digital é uma decisão política que se sobrepõe à econômica. A tecnologia que está sendo desenvolvida pelos norte-americanos com o intuito de coibir a copiagem não autorizada (a pirataria) deverá vir com atrativos como, por exemplo, a excelência de um padrão visual impossível de ser repetida pelos brasileiros, e que os exibidores não exitarão em sua escolha.

O produtor de hoje também tem que estar atento ao encarecimento da produção. Em um período de sete anos, de 1995 a 2001, os recursos investidos em produção cresceram 18 vezes, ao passo que a quantidade de filmes lançados no mesmo período apenas dobrou (Almeida \& Butcher, 2003, p. 32). Levanto algumas hipóteses:

- O ciclo da retomada começou com um real valendo um dólar. Em 2002, essa relação chegou a 4 reais para um dólar. Hoje, está estável em 2,5 de real para 1 dólar (aproximadamente). Os custos de nossa produção acompanharam as altas do dólar, mas não acompanharam as baixas.

- Tivemos, de 1996 até hoje, uma inflação acumulada de $410 \%{ }^{134}$.

- Ficaremos cada vez mais dependentes de tecnologia importada se não apoiarmos experiências como as da Rain Brasil. A introdução de sistemas digitais de exibição com tecnologia norte-americana encarecerá a produção se essa for a única opção do mercado exibidor.

- Os sistemas Multiplex exigem lançamentos com um grande número de cópias, pois oferecem o mesmo número de títulos na maior quantidade possível de salas e por um curtíssimo período de tempo. O filme tem que lucrar em um curto

${ }^{134}$ O índice utilizado é o IPCA / IBGE - http://www.portalbrasil.eti.br/ipca.htm, último acesso em 01/02/2007. 
período de tempo e tem que apresentar em seu orçamento de produção a estratégia de lançamento e os custos das cópias.

- Os custos de lançamento são bancados pelo produtor que, já no projeto de captação, tem que apresentar sua janela de exibição, mesmo sem contrato firmado com a distribuidora.

- Como conseqüência dos itens anteriores, os custos de publicidade de lançamento de um filme são crescentes pois há a necessidade de lançamentos cada vez mais impactantes.

No mercado exibidor, os desafios para a produção também estão postos.

As salas de cinema no Brasil atingem um público médio de sete milhões de espectadores nas salas de cinema. E um filme brasileiro atinge, no máximo, 4 milhões. (Machado et al., 2005, p.68) ${ }^{135}$. Esse número corresponde a menos de $10 \%$ do total da população brasileira.

Ainda segundo o relatório do IPT, a possibilidade de aumento de público vem com a recomendação de "ampliação do parque exibidor, atingindo cidades do interior e periferia das grandes cidades. A ampliação do número de salas deve ser estimulada, com redução do preço do ingresso e gestão privada, com apoio governamental, podendo-se usar o modelo das PPP - Parcerias Público-Privadas." (Machado et al., 2005, p.68).

Longe de ser resolvida, a produção de filmes brasileiros continua girando em círculos. As expectativas se concentram na busca de produtor que seja capaz de alinhar seu projeto à cadeia de distribuição e exibição. Além disso, ele deverá ter um posicionamento claro em relação às políticas adotadas. Também espera-se que tenha uma formação na área cinematográfica, capaz de oferecer soluções criativas sem que o projeto proposto perca sua identidade. Ou seja, busca-se também um novo perfil de produtor.

Estes desafios são pontos de um debate que tem se estendido no decorrer da história e a situação que temos hoje é que o cinema da retomada não conseguiu ocupar o mercado de uma forma consistente a ponto de garantir sua autosustentabilidade, como estava previsto na época do lançamento da Lei do Audiovisual $^{136}$.

\footnotetext{
135 Dados retirados do Relatório TÉCNICO IPT/DEES № 81507 - 205, elaborado pelo IPT - Instituto de Pesquisas Tecnológicas do Estado de São Paulo da Secretaria da Ciência, Tecnologia e Desenvolvimento Econômico do Estado de São Paulo, de agosto de 2005, intitulado: "Propostas de políticas públicas para o aumento da competitividade do segmento de cinema paulista".

${ }^{136} \mathrm{Na}$ época do lançamento da Lei do Audiovisual previa-se que em 10 anos ela poderia deixar de existir porque esse era um tempo suficiente para o cinema brasileiro alcançar sua autosustentabilidade. Em 2003, a data de expiração da lei foi prorrogada para 2007. O debate sobre o novo adiamento da data de expiração já começou.
} 


\section{Conclusões:}

1) Durante o Seminário "Tendências e Perspectivas do Negócio Audiovisual", ao ouvir as falas de Valmir Fernandes, presidente da Abraplex e gerente geral da Cinemark Brasil ${ }^{137}$ e de Rodrigo Saturnino Braga, diretor geral da divisão cinema da Columbia Tristar Buena Vista do Brasil $^{138}$, constato que o mesmo raciocínio que permeava a fala do dirigente da Companhia Cinematográfica Brasileira, em 1911, permanece na fala dos atuais comandantes da indústria cinematográfica.

Reproduzo as falas de Fernandes e Braga durante a mesa "Diagnóstico do Mercado: "Se o filme brasileiro puder apresentar competitividade com o filme norte-americano em termos de qualidade de produção (tecnologia e financiamento) e de aceitação de público (mercado), terá sempre espaço para ser exibido em qualquer cinema do mundo."

Além disso, o editorial que está na página principal do site da Abraplex diz:

"Os grandes filmes nacionais produzidos com uma visão de mercado não têm dificuldade de competir em igualdade de condições com o cinema americano. Provaram que não necessitam da cota de tela. Já os médios, dependem muito mais de recursos de comercialização e de marketing do que de uma cota para atingir seu público. Os filmes brasileiros pequenos, produzidos dentro de um conceito autoral e de relevância cultural, representam cerca $75 \%$ dos títulos lançados anualmente. E são estes que possuem dificuldades de exibição porque não atraem público."139

Em 1911, um dos diretores da Companhia Cinematográfica Brasileira, dizia (repito a transcrição):

"- E as fitas nacionais? A companhia não as exibirá? perguntaram à Companhia Cinematográfica Brasileira. Um dos diretores respondeu: - Também. Mas a Companhia procurará fitas com a mesma perfeição das [fitas de] fábricas estrangeiras." (Souza, 1998, p. 65).

A Cinearte, em 1930, escrevia em seus artigos (repito a transcrição)

"Um cinema que ensina o fraco a não respeitar o forte, o servo a não respeitar o patrão, que mostra caras sujas, barbas crescidas, aspectos sem higiene alguma, sordices e um realismo levado ao extremo não é cinema.

Imaginem um casal de jovens que vão assistir um filme americano médio. Vêem lá um rapaz de cara limpa, bem barbeado, cabelo penteado, ágil, bom cavaleiro. E a moça bonitinha, corpo bem-feito, rosto meigo, cabelos modernos, aspecto todo fotogênico. Depois há o cômico e o vilão, que também são higiênicos e distintos. $E$ ainda uma fazenda moderna, fotogênica, os subordinados se submetem aos seus superiores com alegria e com satisfação, e um ritmo que é o ritmo da vida de hoje, ágil, leve, moderno...

\footnotetext{
137 Maior cadeia de exibição em sistema de multiplex atuando hoje no Brasil

${ }^{138}$ A Columbia Tristar e Buena Vista são duas das sete companhias distribuidoras associadas à MPA $-\mathrm{AL}$.

${ }^{139}$ http://www.abraplex.com.br/index.html, último acesso em 06/02/2007.
} 
O parzinho que assistir o filme comentará que já viu aquilo vinte vezes. Mas sobre seus corações que sonham, não cairá a penumbra de uma brutalidade chocante, de uma cara suja, de um aspecto que tira qualquer parcela de poesia e de encantamento. Essa mocidade não pode aceitar essa arte que ensina a revolta, a falta de higiene, a luta e a eterna briga contra os que têm o direito de manda." $\left(\right.$ Souza, 1998, p. 81) ${ }^{140}$.

Os críticos do Cinema Novo argumentavam que o hermetismo de seus filmes e as mensagens políticas embutidas neles afugentavam o público das salas de cinema.

Carlos Guimarães, presidente do INC, fez a seguinte declaração quando a Embrafilme já estava implantada:

"O cinema brasileiro saiu de uma fase em que a multiplicidade de realizações experimentais e contestatórias provocou uma retração do público. Agora há uma franca procura de narrativas de fácil aceitação popular. O mais importante é que as diversas tendências de produção mantenham-se ligadas com a capacidade de absorção do público, reconheçam que as platéias cinematográficas se mostram dia a dia mais exigentes quanto ao nível técnico e espetacular e se organizem para atender tais requisitos." (Matos Jr apud Ramos, 1983, p. 96) ${ }^{141}$.

Todas essas declarações, ao longo de mais de um século, dizem praticamente a mesma coisa: enquanto não fizermos filmes iguais aos norte-americanos não conseguiremos implantar uma indústria cinematográfica.

O cinema brasileiro tem uma história secular que patina para conseguir se expressar, ser auto-suficiente, fazer filmes iguais aos norte-americanos, construir uma indústria de ponta, para assim, conquistar o mercado.

Esse é um ônus que o cinema brasileiro carrega desde o seu nascimento por não ter construído um projeto para sua indústria cultural. E concordando com Paulo Emílio Salles Gomes, o subdesenvolvimento do país por não ter um projeto político global, inviabiliza a manifestação cinematográfica em qualquer forma que a definam (artística, comercial, industrial, cultural, etc.).

2) O Relatório do IPT nos diz que em países da Comunidade Européia e América Latina (como Argentina), as políticas governamentais subsidiam fortemente suas produções e protegem seu mercado exibidor. No caso da Comunidade Européia, "a política de audiovisual é entendida como tendo um papel primordial na preservação da história, cultura e sociedade européias. Para tanto, foi criada a Convenção Européia para Proteção da Herança Audiovisual. A Convenção é parte do Conselho da União Européia". (Machado et al., 2005, p. 12).

O mesmo relatório diz que a indústria cinematográfica norte-americana é fortemente protegida através de barreiras comerciais com controle de distribuição e caráter oligopolista.

${ }^{140}$ O artigo está transcrito da revista Cinearte de 18 de junho de 1930, no livro de Carlos Roberto de Souza.

${ }^{141}$ Trecho de artigo de Carlos Guimarães de Matos Jr. (então Secretário de Planejamento do INC e, logo depois, presidente), publicado na Filme e Cultura $n^{\circ} 21$, jul./ago.72, Rio de Janeiro, INC. 
Já na Índia há uma situação um pouco diferente, pois quando o cinema estrangeiro chegou lá, o país já possuía uma indústria estabelecida, popular e forte. Produz 800 filmes por ano (contra 400 de Hollywood), para um mercado de onze mil salas exibidoras. Mas, atualmente, ao sentir os efeitos da globalização, seu governo já toma medidas protecionistas como incentivos através de prêmios.

Na América Latina, especialmente na Argentina, os países que produzem filmes em escala possuem institutos estatais que ajudam nos financiamentos e na distribuição. A Argentina produz, em média, 50 filmes por ano, e tem embutido no seu bilhete de cinema impostos que são transferidos para a produção. "O preço de ingresso faz com que a Argentina seja o terceiro mercado em renda bruta de bilheteria na América Latina, apesar de, em termos de público, ser apenas o quinto mercado, ficando atrás de Brasil, México, Cuba e Colômbia" (Machado et al., 2005, p. 24).

Repetindo o que disse no primeiro item, mas agora por outro ângulo, acredito que sem um projeto político o cinema brasileiro não conseguirá se livrar de sua histórica cíclica. As cinematografias construídas em países como França, Itália, Alemanha, Argentina e Estados Unidos têm por trás um projeto de defesa de sua cultura e de sua expressão. Infelizmente nós não temos.

3) Defendo mais uma vez a concepção de alguns pesquisadores de que o cinema brasileiro tem uma história sazonal. No capítulo 2, enumerei os ciclos que construíram a história da cinematografia brasileira. Em todos os ciclos apresentados os três problemas que aponto como insolúveis dentro da nossa história estão presentes: dependência governamental, ou melhor dependência de quem está no governo, dependência tecnológica e mercado dominado por outras cinematografias. Esses três problemas podem ser resolvidos pontualmente. $E$ quando isso aconteceu, iniciaram um novo ciclo. Mas, na falta de um projeto nacional de defesa da cultura, as soluções são facilmente descartadas. E, então, o ciclo se encerra.

4) O "ciclo da retomada" passa por uma fase de esgotamento. Os desafios são enormes e medidas pontuais não garantirá a sua continuidade.

5) Pela própria falta de um projeto, a produção de um filme é feita de acordo com as normas estabelecidas naquele momento. Mudamos nossos modelos ao sabor dos acontecimentos e não por conta de um projeto.

6) Desprezamos nossas experiências passadas. A bem sucedida união do cinema com o rádio (no ciclo das chanchadas), que era o maior meio de comunicação de massa nas décadas de 40 e 50, nunca mais foi repetida. Nos tempos atuais, 50 anos depois, estamos começando a discutir um tipo de parceria entre cinema e televisão, depois de algumas experiências bem-sucedidas promovidas pela Rede Globo. Mas a Rede Globo também tem se ocupado em realizar suas próprias produções. Não se pode desprezar uma experiência como essa, mas, como já vimos, é ingênuo dizer que o mercado é livre e há espaço para essa competitividade.

7) A atuação do produtor gera expectativas. Há a necessidade de um profissional melhor preparado, que deixe de ser um "cavador" e passe a ter uma atuação que possibilite a construção de um projeto de preservação da cultura brasileira. 
São muitos os desafios para a nossa produção.

E a intenção deste trabalho é a reflexão sobre a produção de filmes no Brasil e a atuação de um produtor que se diferencie e seja capaz de ajudar o país a construir um projeto de manifestação artística e cultural. 


\section{Referências Bibliográficas:}

ABREU, Nuno Cesar. Boca do lixo. Cinema e classes populares. Campinas: Unicamp, 2006.

ALBERSTAT, Philip. The insiders's guide to film finance. Oxford: Focall Press, 2004.

ALMEIDA, Luis Otávio Araújo de. 2003. Modelo conceitual para previsão do potencial de sucesso econômico de novos filmes. São Paulo: Dissertação de Mestrado, Escola de Comunicações e Artes da Universidade de São Paulo.

ALMEIDA, Paulo Sérgio; BUTCHER, Pedro. Cinema: desenvolvimento e mercado. Rio de Janeiro: Aeroplano, 2003.

AUGUSTO, Sérgio. Esse mundo é um pandeiro. São Paulo: Companhia das Letras, 1989.

BASTOS, Pedro Paulo Zahluth. 2005. "A diplomacia do dólar: moeda e império (1898-1914)". Disponível em: http://www.eco.unicamp.br/aspscripts/boletim_ceri/boletim/boletim4/06_PedroPaulo.pdf. (06/02/07).

BERNARDET, Jean-Claude. Cinema Brasileiro: Propostas para uma história, São Paulo: Paz e Terra, 1978.

Paulo: Annablume, 2004. . Historiografia clássica do cinema brasileiro. São

BITELLI, Marcos Alberto Sant'Anna. O direito da comunicação e da comunicação social. São Paulo: Revista dos Tribunais, 2003.

BONASIO, Valter. Televisão: manual de produção e direção. Belo Horizonte: Editora Leitura, 2002.

BORDWELL, David; STEIGER, Janet; THOMPSON, A.J. The classical Hollywood cinema - film styke and mode of production to 1960. New York: Columbia University Press, 1985.

CAETANO, Daniel (org). Cinema brasileiro. 1995 - 2005. Ensaios sobre uma década. Rio de Janeiro: Azougue, 2005.

CALIL, Carlos Augusto. Cinema e indústria. Rio de Janeiro: Imago, 1996.

EBERT, Carlos. 2000. "Pequena história da cinematografia no Brasil". Disponível em: http://www.abcine.org.br/ABC_html/textos/hist_cineg_br/historia.html. $(08 / 11 / 2006)$.

GALVÃO, Maria Rita. Burguesia e cinema. O caso Vera Cruz. São Paulo: Civilização Brasileira, 1981. 
GATTI, Andre Piero. 1999. O consumo e o comércio cinematográficos no Brasil vistos através da distribuição de filmes nacionais empresas distribuidoras e filmes de longa-metragem (1966-1990). São Paulo: Dissertação de Mestrado, Escola de Comunicações e Artes da Universidade de São Paulo.

GERBASE, Carlos. Impactos das tecnologias digitais na narrativa cinematográfica. Porto Alegre: EDIPUCRS, 2003.

GOMES, Paulo Emílio Salles. Cinema: trajetória no subdesenvolvimento. São Paulo: Paz e Terra, 2001.

KELLISON, Cathrine. Produção e direção para TV e vídeo. Uma abordagem prática. Rio de Janeiro: Elsevier, 2006.

LABAKI, Amir. O cinema brasileiro. São Paulo: Publifolha, 1998.

LUCA, Luiz Gonzaga Assis de. Cinema digital - Um novo cinema? São Paulo: Imprensa Oficial / TV Cultura, 2004.

LUMET, Sidney. Making movies. New York: Vintage books, 1995.

MACHADO, Arlindo. Pré-cinemas e pós-cinemas. Campinas: Papirus, 1997.

MCKERNAN, Brian. Digital cinema. New York: Mcgraw-Hill Professional, 2005.

MORAES, Malu. Perspectivas estéticas do cinema brasileiro. Brasília: Editora Universidade de Brasília, 1986.

NAGIB, Lúcia. O cinema da retomada. São Paulo: Editora 34, 2002.

ORICCHIO, Luiz Zanin. Cinema de novo. Um balanço crítico da retomada. São Paulo: Estação Liberdade, 2003.

RAMOS, Fernão; MIRANDA, Luiz Felipe. Enciclopédia do Cinema Brasileiro, São Paulo: Senac, 2000.

RAMOS, José Mário Ortiz. Cinema, estado e lutas culturais (anos 50 / 60 /70). São Paulo: Paz e Terra, 1983.

REICHENBACK, Carlos. Arte em revista, n. 5, ed. kairós, sp, mai 81

ROCHA,Glauber; XAVIER, Ismail (org.). Revisão Crítica do Cinema Brasileiro. São Paulo: Cosac \& Naif, 2003.

RODRIGUES, Chris. O cinema e a produção. Rio de Janeiro: DP\&A Editora, 2002.

SALEM, Helena. Nelson Pereira dos Santos: o sonho possível do cinema brasileiro. Rio de Janeiro: Nova Fronteira, 1987. 
SCHATZ, Thomas. O gênio do sistema. A era dos estúfdios em Hollywood. São Paulo: Companhia das Letras, 1988.

SCHVARZMAN, Sheila. Humberto Mauro e as imagens do Brasil. São Paulo: Unesp, 2004.

SIMIS, Anita. Estado e cinema no Brasil. São Paulo: Annablume, 1996.

SOUZA, Carlos Roberto de. Nossa aventura na tela. São Paulo: Cultura Editores, 1998.

SOUZA, José I. de Melo. 2001. "Francisco Serrador e a primeira década do cinema em São Paulo". Disponível em http://www.mnemocine.com.br/cinema/historiatextos/serrador.htm (06/02/2007).

STIGLITZ, Joseph. 2001. "Information and the change in the paradigm in economics". Disponível em: http://www2.gsb.columbia.edu/faculty/jstiglitz/download/2002_Information_and_the_ Change_Nobel.pdf (10/11/2006)

VINAY, Alex. Introdução ao Cinema Brasileiro, Rio de Janeiro: Revan, 1983.

XAVIER, Ismail. Alegorias do subdesenvolvimento. São Paulo: Brasiliense, 1983. . Cinema brasileiro moderno. São Paulo: Paz e terra, 2004.

. Comunicação de massa em ritmo de indústria cultural. São Paulo: Sesc-Paulista, 1991. 


\section{Sites consultados:}

http://www.abcine.org.br (08/11/2006)

http://www.abraplex.com.br/ (06/002/07)

http://www.adorocinemabrasileiro.com.br/hotsites/cinedia/cinedia_historia.asp (06/002/07)

http://www.ancine.gov.br/ (06/002/07)

http://www.cinemabrasil.org.br/ (06/002/07)

http://www.cinemando.com.br/200211/historico/chanchadas.htm (06/002/07)

http://www.chambel.net/ (06/002/07)

http://www.cultura.gov.br/ (06/002/07)

http://houaiss.uol.com.br/busca.jhtm (06/002/07)

http://www.eco.unicamp.br (06/002/07)

http://www.imdb.com (05/12/2006)

http://www.mnemocine.com.br (08/11/2006)

http://www.mpa-al.com.br/ (06/002/07)

http://www.oscars.org/mhl/sc/selig_162.html (06/002/07)

http://www.rain.com.br/opencms/opencms/rain/index.html (06/002/07)

http://www.uff.br/direito/artigos/lac-03.htm (06/002/07) 


\section{ANEXO I - PRIMEIRA LEI DE PROTEÇÃO AO CINEMA BRASILEIRO ${ }^{142}$}

\section{DECRETO N. 21.240 - DE 4 DE ABRIL DE $1932\left({ }^{\left({ }^{143}\right)}\right.$}

Nacionalizar o serviço de censura dos filmes cinematográficos, cria a "Taxa Cinematográfica para a educação popular" e dá outras providências

O Chefe do Governo Provisório da República dos Estados Unidos do Brasil, usando das atribuições que lhe confere o art. $1^{\circ}$ do decreto n. 19. 398, de 11 de novembro de 1930:

Considerando que o cinema, sobre ser um meio de diversão, de que o público já não prescinde, oferece largas possibilidades de atuação em benefício da cultura popular, desde que convenientemente regulamentado;

Considerando que os favores fiscais solicitados pelos interessados na indústria e no comércio cinematográfico, uma vez concedidos mediante compensações de ordem educativa, virão incrementar, de fato, a feição cultural que o cinema deve ter;

Considerando que a redução dos direitos de importação dos filmes impressos virá permitir a reabertura de grande número de casas de exibição, com o que lograrão trabalho numerosos desempregados;

Considerando, tambem, que a importação do filme virgem, negativo e positivo, deve ser facilitada, porque é matéria prima indispensável ao surto da indústria cinematográfica no país;

Considerando que o filme documentário, seja de carater cientifico, histórico, artístico, literário e industrial, representa, na atualidade, um instrumento de inigualavel vantagem, para a instrução do público e propaganda do país, dentro e fora das fronteiras;

Considerando que os filmes educativos são material de ensino, visto permitirem assistência cultural, cora vantagens especiais de atuação direta sobre as grandes massas populares e, mesmo, sobre analfabetos ;

Considerando que, a exemplo dos demais países, e no interesse da educação popular, a censura dos filmes cinematográficos deve ter cunho acentuadamente cultural; e, no sentido da própria unidade da nação, como vantagens para o público, importadores e exibidores, deve funcionar como um serviço único, centralizado na capital do país,

\section{DECRETA:}

Art. $1^{\circ}$ Fica nacionalizado o serviço de censura dos filmes cinematograficos, nos termos do presente decreto.

Art. $2^{\circ}$ Nenhum filme pode ser exibido ao público sem um certificado do Ministério da Educação e Saude Pública, contendo a necessária autorização.

Art. $3^{\circ}$ Esse certificado será fornecido ou denegado, após projeção integral do filme, perante a comissão de censura, de que trata 0 art. $6^{\circ}$ e pagamento da importância devida pela "Taxa Cinematográfica para a educação popular".

Parágrafo único. Em nenhum ponto do território nacional os filmes certificados pelo Ministério da Educação e Saude Pública podem ser sujeitos á outra qualquer censura ou revisão.

Art. $4^{\circ}$ Quando, de um mesmo filme, existirem várias cópias, apenas uma será submetida á censura, expedindo-se, porem, tantos certificados quantas forem as cópias apresentadas, as quais pagarão apenas o devido por esses certificados.

Art. $5^{\circ}$ Os produtores nacionais poderão requerer, antes da fabricação de um filme, exame do respectivo cenário; para isso, deverão entregar á comissão de censura, em duplicata, a descrição integral do filme e prova do pagamento da taxa de cinquenta mil réis.

Parágrafo único. A aprovação prévia não exime o filme nacional das exigências aos arts. $2^{\circ}$ e $3^{\circ}$.

Art. $6^{\circ}$ A comissão de censura será assim composta:

a) de um representante do Chefe de Polícia;

b) de um representante do Juizo de Menores;

c) do diretor do Museu Nacional;

d) de um professor designado pelo Ministério da Educação e Saude Pública;

e) de uma educadora, indicada pela Associação Brasileira de Educação.

${ }^{142}$ Extraído do site da ANCINE http://www.ancine.gov.br/cgi/cgilua.exe/sys/start.htm?sid=69

143 (*) Decreto n. 21.240, de 4 de abril de 1932 - Retificação publicada no Diário Oficial de 12 de agosto de 1932 : "Art. 23. Leia-se: arts., 2º, $8^{\circ}$ e $\S \S 2^{\circ}, 9^{\circ}, 12$ e 13 - e não como está" 
$\S 1^{\circ}$ Todos os membros indicados deverão residir no Distrito Federal, e sua designação é válida por um ano, podendo ser reconduzidos.

$\S 2^{\circ} \mathrm{O}$ ministro da Educação e Saude Pública designará um dos membros da Comissão para servir como presidente, e um funcionário do Ministério para desempenhar as funções de secretárioarquivista, bem como três suplentes para substituirem os membros efetivos da comissão, nos casos de impedimento.

$\S 3^{\circ}$ Sempre que julgar necessário, em relação a filmes de natureza técnica, a comissão solicitará o concurso de especialistas no assunto, para isso convidados pelo Ministério da Educação e Saude Pública.

Art. $7^{\circ} \mathrm{Em}$ cada exame a Comissão decidirá:

I. Se o filme pode ser integralmente exibido ao público.

II. Se deve sofrer cortes, e quais.

III. Se deve ser classificado, ou não, como filme educativo.

IV. Se deve ser declarado impróprio para menores.

V. Se a exibição deve ser inteiramente interditada.

$\S 1^{\circ}$ Nos casos dos itens I, III e IV, constará sempre, no certificado a ser expedido, a decisão da comissão de censura.

$\S 2^{\circ}$ Todo material destinado ao anúncio do filme, constante de fotografias, cartazes, gravuras ou dísticos, deverá ser tambem submetido ao juízo da comissão, que excluirá o que lhe parecer nocivo.

$\S 3^{\circ}$ Serão considerados educativos, a juízo da comissão não só os filmes que tenham por objeto intencional divulgar conhecimentos científicos, como aqueles cujo entrecho musical ou figurado se desenvolver em torno de motivos artísticos, tendentes a revelar ao público os grandes aspetos da natureza ou da cultura.

Art. $8^{\circ}$ Será justificada a interdição do filme, no todo ou em parte, quando:

I. Contiver qualquer ofensa ao decoro público.

II. For capaz de provocar sugestão para os crimes ou maus costumes.

III. Contiver alusões que prejudiquem a cordialidade das relações com outros povos.

IV. Implicar insultos a coletividade ou a particulares, ou desrespeito a credos religiosos.

V. Ferir de qualquer forma a dignidade nacional ou contiver incitamentos contra a ordem pública, as forças armadas e o prestígio das autoridades e seus agentes.

$\S 1^{\circ} \mathrm{A}$ impropriedade dos filmes para menores será julgada pelo Comissão tendo em vista proteger o espírito infantil e adolescente contra as sugestões nocivas e o despertar precoce das paixões.

$\S 2^{\circ} \mathrm{A}$ exibição dos filmes certificados, com a restrição de "impróprios para menores", só poderá ser 'feita se em anúncio publicado na imprensa, e em cartaz bem visivel colocado na bilheteria, se declarar essa impropriedade.

Art. $9^{\circ} \mathrm{O}$ certificado da comissão de censura será sempre projetado na tela todas as vezes que for exibido o filme. entre o título e outras indicações das casas produtoras, e o entrecho do mesmo filme.

Art. 10. A exibição cinematográfica que contrarie o julgamento da Comissão, quer se trate de cenas, de legendas, de títulos ou de parte falada ou cantada, bem como de cartazes, fotografias e quaisquer anúncios, ou da falta de reprodução do certificado de censura, será punida, nos termos das instruções regulamentares :

I.Com multa variavel de 500\$0 a 5:000\$0.

II. Com apreensão do filme.

III. Com a cassação ao exibidor da licença para que seu estabelecimento funcione.

$\S 1^{\circ}$ As penalidades I e II serão tambem impostas aos produtores nacionais e aos comerciantes e locadores de filmes que tiverem compartilhado, com o exibidor, a responsabilidade na violação da lei. $\S 2^{\circ}$ Nenhum filme será registado para garantia de direitos autorais sem que, á petição para registo esteja presente o certificado de censura.

Art. 11. Os locadores de filmes ficam obrigados a juntar no início ou no fim de cada película, as legendas de propaganda educativa que o Ministério da Educação e Saude Pública para isso Ihes forneça, já impressas, e desde que não excedam a dez metros de extensão.

Art. 12. A partir da data que for fixada, por aviso, do Ministério da Educação e Saude Pública, será obrigatório, em cada programa, a inclusão de um filme considerado educativo, pela Comissão de Censuras.

Art. 13. Anualmente, tendo em vista a capacidade do mercado cinematográfico brasileiro, e a quantidade e a qualidade dos filmes de produção nacional, o Ministério da Educação e Saude Pública fixará a proporção da metragem de filmes nacionais a serem obrigatoriamente incluidos na programação de cada mês.

Art. 14. A infração do disposto nas instruções que forem baixadas em cumprimento dos arts. 12 e 13, sujeitará o exibidor á multa de $200 \$ 0$ em cada comissão. 
Parágrafo único. Se pelo não cumprimento dessas instruções forem responsaveis as firmas locadoras de filmes, proceder-se-á contra essas firmas, nos termos do $\S 1^{\circ}$ do art. 10.

Art. 15. Dentro do prazo de 180 dias, a contar da data da publicação deste decreto, realizar-se-á, na Capital da República, sob os auspícios do Ministério da Educação e Saude Pública, e segundo as instruções que este baixar, o Convênio Cinematográfico. Educativo.

$\S 1^{\circ}$ Serão fins principais do Convênio:

I. A instituição permanente de um cine-jornal, com versões tanto sonoras como silenciosas, filmado em todo o Brasil e com motivos brasileiros, e de reportagens em número suficiente, para inclusão quinzenal, de cada número, na programação dos exibidores.

II. A instituição permanente de espetáculos infantis, de finalidade educativa, quinzenais, nos cinemas públicos, em horas diversas das sessões populares.

III. Incentivos e facilidades econômicas às empresas nacionais produtoras de filmes. e aos distribuidores e exibidores de filmes em geral.

IV. Apoio ao cinema escolar.

$\S 2^{\circ}$ Como favores do Governo Federal poderão figurar, no contexto do Convênio, a redução ou isenção de impostos e taxas, a redução de despesas de transportes e quaisquer outras vantagens que estiverem na sua alçada.

Art. 16. A tarifa alfandegária para a importação de filmes cinematográficos comuns fica reduzida a $10 \$ 0$ por kg., razão de 15\%; e a de importação de filmes de $16 \mathrm{~mm}$. e $9 \mathrm{~mm}$. de largura é fixada em $5 \$ 0$ por $\mathrm{kg}$., razão de $15 \%$.

Art. 17. A partir de 30 dias da data da publicação deste decreto, a tarifa alfandegária para a importação do filme virgem, negativo ou positivo, e bem, assim dos filmes impressos, classificados como educativos pela comissão de censura, será de $1 \$ 0$ (mil réis) por kg., razão de $15 \%$.

Art. 18. Fica criada a "taxa cinematográfica para a educação popular", a ser cobrada por metragem, à razão de $\$ 3$, por metro, de todos os filmes apresentados à censura, qualquer que seja o seu número de cópias, nos termos do art. $4^{\circ}$.

Art. 19. A taxa acima referida será recolhida à tesouraria do Departamento Nacional do Ensino, que dela manterá escrituração especial.

Art. 20. Os certificados de censura pagarão em selo $10 \$ 0$ pela primeira via e $5 \$ 0$ pelas demais.

Art. 21. O ministro da Educação e Saude Pública expedirá as instruções necessárias à execução do presente decreto.

Parágrafo único. Essas instruções, que poderão ser modificadas pelo ministro, de acordo com os dados da experiência e sempre que as circunstâncias o exigirem, disporão sobre o modo de funcionamento da comissão de censura, condições a que devem obedecer os certificados, remunerações aos membros da comissão, processo de arrecadação e aplicação da "taxa cinematográfica para a educação popular", e casos omissos.

Art. 22. No Ministério da Educação e Saude Pública, dentro da renda da taxa cinematográfica instituida neste decreto, será oportunamente criado um órgão técnico, destinado não só a estudar e orientar a utilização do cinematógrafo, assim como dos demais processos técnicos que sirvam como instrumentos de difusão cultural.

Art. 23. Ás autoridades policiais, em todo o território nacional, incumbe a fiscalização das exibições cinematográficas, afim de verificar se as mesmas obedecem ao disposto nos arts. $2^{\circ}, 8^{\circ}, \S \S 2^{\circ}$ e $3^{\circ}$, 9o, 12 e 13.

Parágrafo único. Para esse fim, os exibidores deverão apresentar os certificados de censura, sempre que estes Ihes forem exigidos, e, quando se estabelecer a inclusão obrigatória de filmes de produção nacional, os comprovantes da programação de cada mês, segundo o que estatuirem as instruções a serem baixadas.

Art. 24. Este decreto entrará, em vigor, no Distrito Federal, 10 dias após a data da sua publicação no Diário Oficial, e 'nos demais pontos do território nacional noventa dias depois dessa data.

Parágrafo único. Os filmes até então censurados por forma diferente da estabelecida no presente decreto terão livre curso.

Art. 25. Revogam-se as disposições em contrário.

Rio de Janeiro, 4 de abril de $1932,111^{\circ}$ da Independência e $44^{\circ}$ da República.

GETULIO VARGAS

Francisco Campos

Oswaldo Aranha 


\section{DECRETO N. 22.337 - DE 10 DE JANEIRO DE 1933}

Altera o art. 23 do decreto n. 21.240, de 4 de abril, de 1932

O Chefe do Govêrno Provisório da República dos Estados Unidos do Brasil:

Resolve :

Artigo unico. $O$ art. 23 do decreto n. 21.240 de 4 de abril de 1932, passará a ter a seguinte vedação: A's autoridades policiais, em todo o territorio nacional, incumbe a fiscalização das exibições cinematograficas, afim de verificar si as mesmas obedecem ao disposto nos art. $2^{\circ}, 8^{\circ}$, $\S \S 1^{\circ}$ e $2^{\circ}, 3^{\circ}$, $9^{\circ}, 12$ e 13. A apresentação do certificado de censura não prescinde da autorização do autor ou pessoa subrogada nos direitos deste, para que as autoridades policiais competentes aprovem os programas dos espetaculos cinematograficos, e dêm a respectiva licença para a realização dos mesmos, de acôrdo com o art. 29 do decreto n. 5.492, de 16 de julho de 1928, e com os arts. 43 e seus paragrafos e 46 do decreto nomero 18.527, de 10 de dezembro de 1928, combinados com o art. $2^{\circ}$ do decreto $\mathrm{n}, 4.790$, de 2 de janeiro de 1924, revogadas as disposições em contrario.

Rio de Janeiro, 10 de janeiro de $1933,112^{\circ}$ da Independencia e $45^{\circ}$ da República.

\section{GETULIO VARGAS}

Washington F. Pires 
ANEXO II - CRIAÇÃO DO INC ${ }^{144}$

DECRETO Nº 60.220, DE 15 DE FEVEREIRO DE 1967

Aprova o Regulamento do Instituto Nacional de Cinema.

O PRESIDENTE DA REPÚBLICA, usando da atribuição que the confere o artigo 87, item I, da Constituição, e tendo em vista o disposto no Decreto-lei no 43 , de 18 de novembro de 1966,

DECRETA:

Art $1^{\circ}$ Fica aprovado o Regulamento do Instituto Nacional de Cinema, que a êste acompanha, assinado pelo Ministro de Estado da Educação e Cultura.

Art $2^{\circ}$ Êste decreto entrará em vigor na data da sua publicação, revogadas as disposições em contrário.

Brasília, 15 de fevereiro de $1967 ; 146^{\circ}$ da Independência e $79^{\circ}$ da República.

H. CASTELLO BRANCO

Raymundo Moniz de Aragão

REGULAMENTO DO INSTITUTO NACIONAL DE CINEMA

CAPÍTULO I

Da Finalidade

Art $1^{\circ} \mathrm{O}$ Instituto Nacional de Cinema (INC), criado pelo Decreto-lei $\mathrm{n}^{\circ} 43$, de 18 de novembro de 1966, é uma autarquia federal, com autonomia técnica, administrativa e financeira, diretamente subordinada ao Ministério da Educação e Cultura e tem por finalidade formular e executar a política governamental relativa à produção, importação, distribuição e exibição de filmes, ao desenvolvimento da indústria cinematográfica brasileira, ao seu fomento cultural e à sua promoção no exterior.

Art $2^{\circ} \mathrm{O}$ INC terá sede e fôro no Estado da Guanabara.

Art $3^{\circ}$ Ao INC compete:

I - formular e executar a política governamental relativa ao desenvolvimento da indústria cinematográfica brasileira, ao seu fomento cultural e à sua promoção no exterior;

II - regular, em cooperação com o Banco Central da República do Brasil, a importação de filmes estrangeiros para exibição em cinemas e televisão;

III - regular a produção, distribuição e a exibição de filmes nacionais fixando preços de locação, prazos de pagamento e condições;

IV - regular condições de locação de filmes estrangeiros às salas exibidoras nacionais;

$\mathrm{V}$ - formular a política nacional de preços de ingressos, evitando tabelamentos que deteriorem as condições econômicas do cinema;

VI - conceder financiamento e prêmios a filmes nacionais, de acôrdo com normas elaboradas pelo Conselho Deliberativo e aprovadas pelo Ministro da Educação e Cultura;

VII - manter um registro de produtores, distribuídores e exibidores com dados sôbre os respectivos estabelecimentos;

VIII - aprovar, para a concessão de estimulos pelo Poder Público projetos de desenvolvimento da indústria cinematográfica;

IX - produzir e adquirir filmes e diafilmes educativos ou culturais para fornecimento a estabelecimentos de ensino e entidades congêneres ou para projeção sem finalidade lucrativa;

$X$ - selecionar filmes para participar em certames internacionais e orientar a representação brasileira nessas reuniões;

XI - estabelecer normas de co-produção cinematográfica com outros países e regulamentar à realização de produções estrangeiras no Brasil;

144 Decreto extraído do site da ANCINE:

http://www.ancine.gov.br/cgi/cgilua.exe/sys/start.htm?infoid=225\&sid=69 
XII - fiscalizar, em todo o território nacional, o cumprimento das leis e regulamentos das atividades cinematográficas;

XIII - arrecadar as suas rendas e estabelecer prazos para o seu recolhimento;

XIV - aplicar multas e demais penalidades previstas no Decreto-lei número 43, de 18-11-66.

\section{CAPÍTULO II}

Da Organização

Art $4^{\circ} \mathrm{O}$ INC terá a seguinte organização:

a) Presidente;

b) Conselho Deliberativo;

c) Conselho Consultivo;

d) Secretaria-Executiva.

Art $5^{\circ}$ A Presidência terá um Gabinete.

\section{CAPÍTULO III}

Da Competência dos Órgãos da Administração

Art $6^{\circ}$ Compete ao Presidente:

a) Presidir o Conselho Deliberativo;

b) Representar legalmente o INC;

c) Dirigir, orientar e coordenar tôdas as atividades da Autarquia.

Art $7^{\circ} \mathrm{O}$ Conselho Deliberativo é constituído dos seguintes membros:

1) Representante do Ministério da Educação e Cultura;

2) Representante do Ministério da Justiça e Negócios Interiores;

3) Representante do Ministério da Indústria e do Comércio;

4) Representante do Ministério das Relações Exteriores;

5) Representante do Ministro Extraordinário para o Planejamento e Coordenação Econômica;

6) Representante do Banco Central da República do Brasil.

$\S 1^{\circ}$ Os representantes e seus substitutos serão indicados pelos respectivos órgãos e designados pelo Presidente da República.

$\S 2^{\circ} \mathrm{O}$ Conselho Deliberativo reunir-se-á, ordinàriamente duas vêzes por mês.

$\S 3^{\circ}$ As decisões do Conselho Deliberativo serão tomadas sob a forma de Resolução, com base em trabalhos e pareceres da Secretaria Executiva.

$\S 4^{\circ}$ Das decisões do Conselho Deliberativo caberá recurso para o Ministro da Educação e Cultura.

Art $8^{\circ}$ Compete ao Conselho Deliberativo:

a) aprovar o programa anual de trabalho do INC e o Orçamento Analítico para aplicação dos recursos do órgão, a serem homologados pelo Ministro da Educação e Cultura;

b) atualizar, em dezembro de cada ano, para vigorar no exercício seguinte, o valor da contribuição a que se refere o inciso II do artigo 11 do Decreto-lei $n^{\circ} 43$, de 18-11-66, obedecidos nos índices de correção monetária aprovados pelo Conselho Nacional de Economia;

c) estabelecer, em cooperação com o Banco Central da República, normas para importação de filmes estrangeiros, destinados à exibição em cinemas e televisão;

d) aprovar a definição de filme nacional de curta e longa metragem, a ser submetida ao Poder Executivo;

e) provar porcentagens máximas de distribuição de filmes nacionais de longa e curta metragem;

f) fixar o número de dias, por ano, para exibição obrigatória de filmes nacionais em todos os cinemas existentes no território nacional;

g) estabelecer preços de locação, prazos de pagamento e condições para a exibição de filmes nacionais;

h) estabelecer normas para locação de filmes estrangeiros às salas exibidoras nacionais;

i) formular a política nacional de preços de ingressos evitando abelamentos que deteriorem as condições econômicas do cinema;

j) estabelecer normas para concessão de financiamentos e prêmios a filmes nacionais;

I) aprovar, para concessão de estímulos pelo poder público, projetos de desenvolvimento da indústria cinematográfica; 
m) estabelecer normas para a seleção de filmes nacionais que irão participar de festivais e outros certames internacionais;

n) estabelecer normas para assinaturas de acôrdos para assinaturas de acôrdos de co-produção cinematográfica entre o Brasil e outros Países;

o) regular a realização de produções estrangeiras no Brasil.

Art $9^{\circ} \mathrm{O}$ Conselho Deliberativo se reunirá a presença mínima de quatro (4) membros, inclusive o Presidente.

Parágrafo único. As decisões serão tomadas por maioria simples, cabendo ao Presidente o voto de desempate.

Art 10. O Conselho Consultivo é constituído dos seguintes membros:

a) Representante dos produtores de cinema;

b) Representante de distribuidores de filmes;

c) Representante de exibidores de filmes;

d) Representante da crítica cinematográfica;

e) Representante de diretores de cinema.

$\S 1^{\circ}$ Os membros do Conselho Consultivo serão nomeados pelo Ministro da Educação e Cultura, dentre os indicados em lista tríplice, para cada vaga, pelas respectivas entidades nacionais de classe, com mandato de 2 (dois) anos, renovável, desde que novamente incluído na lista tríplice organizada pela classe representada.

$\S 2^{\circ} \mathrm{Na}$ falta de indicação da respectiva entidade nacional de classe, o representante será nomeado pelo Ministro da Educação e Cultura, por indicação do Presidente do INC.

$\S 3^{\circ} \mathrm{O}$ Conselho Consultivo reuni-ser-á, ordinàriamente, uma vez por mês.

$\S 4^{\circ}$ As decisões do Conselho Consultivo serão tomadas sob a fôrma de indicações ao Conselho Deliberativo.

Art 11. Compete ao Conselho Consultivo:

a) apresentar à Secretaria-Executiva proposta sôbre matérias a serem submetidas ao Conselho Deliberativo;

b) manifestar-se, quando solicitado pela Secretaria-Executiva, sôbre matérias a serem examinadas pelo Conselho Deliberativo.

Parágrafo único. É facultado aos membros do Conselho Consultivo comparecer às reuniões do Conselho Deliberativo, para debater, sem direito a voto, matéria relacionada com o setor que representa.

Art 12. O Conselho Consultivo se reunirá com a presença mínima de quatro (4) membros, inclusive o Presidente.

Parágrafo único. As decisões serão tomadas por maioria simples cabendo ao Presidente o voto de desempate.

Art 13. O Conselho Deliberativo e o Conselho Consultivo terão um Secretário para atender aos dois órgãos.

Art 14. Compete à Secretaria-Executiva:

a) elaborar os trabalhos e pareceres para decisão do Conselho Deliberativo;

b) superintender, sob a orientação do Presidente, os trabalhos da Autarquia.

Art 15. Compete ao Secretário-Executivo dirigir a Secretaria-Executiva a presidir o Conselho Consultivo.

Art 16. A Secretaria-Executiva será constituída:

a) Assessoria Técnica, com três assessôres;

b) Departamento do Filme de Longa Metragem;

c) Departamento de Administração.

\section{CAPÍTULO IV \\ Da Competência dos Órgãos Executivos}

Art 17. O Departamento do Filme Educativo será constituído das seguintes divisões:

a) Divisão de Orientação Pedagógica; 
b) Divisão de Produção;

c) Divisão de Distribuição.

$\S 1^{\circ}$ A Divisão de Orientação Pedagógica terá as seguintes seções:

a) Seção de Planejamento e Seleção de Filmes de Diafilmes;

b) Seção de Biblioteca e Documentação.

$\S 2^{\circ}$ A Divisão de Produção terá as seguintes seções:

a) Seção de Orçamentos e Contratos;

b) Seção Técnica;

c) Seção de Edição.

$\S 3^{\circ} \mathrm{A}$ Divisão de Distribuição terá as seguintes seções:

a) Seção de Filmoteca;

b) Seção de Distribuição de Filmes;

c) Seção de Distribuição de Diafilmes.

Art 18. O Departamento do Filme Longa Metragem terá as seguintes divisões:

a) Divisão de Fomento ao Filme Nacional;

b) Divisão de Fiscalização e Estatística.

$\S 1^{\circ}$ - A Divisão de Fomento ao Filme Nacional terá as seguintes seções:

a) Seção de Prêmios e Financiamentos;

b) Seção do Filme Nacional.

$\S 2^{\circ}$ - A Divisão de Fiscalização e Estatística terá as seguintes seções:

a) Seção de Cadastro e Estatística;

b) Seção de Fiscalização.

Art 19. O Departamento de Administração terá as seguintes divisões:

a) Divisão do Pessoal;

b) Divisão Financeira;

c) Divisão de Material e de Serviços Gerais.

\section{CAPÍTULO V \\ Do Patrimônio}

Art 20. O Patrimônio do INC será formado:

I - Pelos bens e direitos que Ihe forem transferidos ou por êle adquiridos;

II - Pelos saldos de rendas próprias.

Art 21. A aquisição de bens imóveis, por parte do INC, depende de autorização do Ministro da Educação e Cultura, e a sua alienação sòmente poderá ser efetuada depois de autorizada pelo Presidente da República.

\section{CAPÍTULO VI}

Do Regime Financeiro

Art 22. A Receita do INC será constituída por:

I - Dotações orçamentárias ou extra-orçamentárias que Ihe forem consignadas pela União;

II - Contribuição para o desenvolvimento da indústria cinematográfica nacional, calculada por metro linear de cópia positiva de todos os filmes destinados à exibição comercial em cinemas ou televisões; III - O produto de operações de crédito;

IV - Os juros de depósitos bancários;

V - Os auxílios, subvenções, contribuições e doações de pessoas jurídicas ou físicas, nacionais ou estrangeiras;

$\mathrm{VI}$ - O produto das multas;

VII - As rendas eventuais.

Art 23. A contribuição a que se refere o inciso II do art. 11 do Decreto-lei no 43 , de 18-11-66 é fixada em Cr $\$ 200$ (duzentos cruzeiros) e será atualizada em dezembro de cada ano, de acôrdo com os índices de correção monetária, aprovados pelo Conselho Nacional de Economia, para vigorar no exercício seguinte.

Parágrafo único. Ficam isentos da contribuição a que se refere o artigo 11, inciso II, do Decreto-lei número 43 , de 18-11-66, os filmes de curta metragem, sem caráter publicitário e os filmes de publicidade e " filmlets " destinados à exibição comercial em televisão. 
Art 24. Os recursos do INC serão aplicados segundo programa anual de trabalho e orçamento analítico, aprovados pelo Conselho Deliberativo e homologados pelo Ministro da Educação e Cultura, em:

I - Despesas com a manutenção dos serviços do INC;

II - Financiamentos a serem concedidos a produtores nacionais;

III - Prêmios a serem atribuídos a filmes nacionais;

IV - Outros encargos previstos em lei.

Parágrafo primeiro - O prêmio a que se refere o inciso III dêste artigo será concedido anualmente a todos os filmes nacionais, proporcionalmente à renda produzida pela sua exibição no País, de acôrdo com as normas a serem fixadas pelo Conselho Deliberativo.

Parágrafo segundo - O produtor nacional poderá ser dispensado pelo INC do recolhimento imediato da contribuição prevista no inciso II do art. 11, do Decreto-lei no 43 de 18 de novembro de 1966, ficando obrigado, porém, a fazê-lo por ocasião do recebimento das parcelas do prêmio que lhe couber até cobrir o montante da contribuição devida ao INC.

Art 25. Nenhum certificado de censura para filmes será concedido pelo Serviço de Censura de Diversões Públicas do Departamento Federal de Segurança Pública, sem a prova do recolhimento da contribuição a que se refere o inciso II, do artigo 11 do Decreto-lei número 43, de 18 de novembro de 1966 ou a prova de sua dispensa, de acôrdo com o $\S 2^{\circ}$ do artigo 14 do mesmo Decreto-lei.

$\S 1^{\circ} \mathrm{O}$ recolhimento será feito à favor do INC, nas Agências do Banco do Brasil S.A.

$\S 2^{\circ}$ Ficam isentos da prova do recolhimento os filmes de curta metragem, sem caráter publicitário e os filmes de publicidade e " filmletes " destinados à exibição comercial em televisão.

Art 26. As contas do Presidente do INC serão prestadas ao Tribunal de Contas da União por intermédio do Ministério da Educação e Cultura, até 30 de abril de cada ano.

\section{CAPÍTULO VII \\ Do Pessoal}

Art 27. O quadro do pessoal do INC será aprovado por decreto do Presidente da República.

Parágrafo único. O Presidente do INC será nomeado pelo Presidente da República, por indicação do Ministro da Educação e Cultura.

Art 28. Para atender à execução de serviços de natureza não permanente ou especializada, poderá o INC admitir pessoal sujeito ao regime da Consolidação das Leis de Trabalho, obedecidas as normas estabelecidas na Lei n 3.780, de 12 de julho de 1960.

\section{CAPÍTULO VIII \\ Da Exibição de Filmes Nacionais}

Art 29. Todos os cinemas existentes no território nacional ficam obrigados a exibir filmes nacionais de longa metragem, durante determinado número de dias por ano a ser fixado pelo Conselho Deliberativo.

$\S 1^{\circ}$ A proposta levará em consideração o desenvolvimento da produção nacional verificada cada ano e as possibilidades de programação do mercado exibidor.

$\S 2^{\circ}$ A reexibição de filme nacional, no mesmo cinema não será computada para os efeitos da exibição compulsória, entendido "re-exibição" como a programação do mesmo filme, transcorrido um determinado período de tempo de sua primeira exibição no mesmo cinema.

$\S 3^{\circ} \mathrm{A}$ exibição compulsória será considerada cumprida, apenas pela metade, quando a receita do produtor nacional fôr atribuída também pela metade.

Art 30. O Poder Executivo definirá em Decreto por proposta do INC, o que é filme nacional de curta e longa metragem.

Parágrafo único. Cabe ao INC conceder o certificado correspondente de cidadania brasileira ao filme produzido no País, nos têrmos da definição a que se refere o presente artigo.

Art 31. O INC poderá conceder a filmes nacionais de curta metragem "Classificação Especial", atendendo ao nível de sua realização e à natureza cultural e educativa. 
Art 32. Todos os cinemas existentes no território nacional ficam obrigados a exibir, durante determinado número de dias, por ano, os filmes nacionais de curta metragem, de "Classificação Especial".

$\S 1^{\circ} \mathrm{O}$ número de dias para exibição obrigatória de filmes de "Classificação Especial" será anualmente fixado pelo Conselho Deliberativo no INC, atendendo ao volume de sua produção que às possibilidades de programação do mercado exibidor.

$\S 2^{\circ} \mathrm{A}$ exibição de filme de "Classificação Especial" isenta os cinemas da obrigatoriedade da exibição, na mesma sessão, de outro filme de curta metragem.

Art 33. Poderão ser projetados, nos cinemas do País, mensagens publicitárias, sob a forma de filmes e " filmlets ".

$1^{\circ}$ Consideram-se " filmlets " os filmes publicitários mudos cuja duração não exceda a quinze segundos.

$\S 2^{\circ}$ As mensagens publicitárias serão projetadas, à meia-luz, no intervalo entre as sessões.

$\S 3^{\circ} \mathrm{A}$ duração máxima do conjunto intervalo será de três (3) minutos.

$\S 4^{\circ} \mathrm{O}$ mesmo filme de publicidade ou " filmlet " só poderá ser incluído na programação do mesmo cinema, durante o máximo de uma semana em cada semestre.

Art 34. Não serão aprovados os programas cinematográficos sem que sejam apresentadas pelo exibidor as provas do cumprimento das normas de proteção ao cinema brasileiro, nos têrmos a serem estabelecidos pelo Conselho Deliberativo.

\section{CAPÍTULO IX \\ Da Distribuição de Filmes Nacionais}

Art 35. A distribuição de filmes nacionais de longa e curta metragem só poderá ser contratada mediante as percentagens máximas que vierem a ser fixadas pelo INC.

$\S 1^{\circ}$ As percentagens de distribuição serão calculadas sôbre a participação do produtor na renda da bilheteria, depois de deduzidas as despesas de publicidade, fiscalização e outras despesas gerais.

$\S 2^{\circ}$ Os contratos para a distribuição de filmes nacionais de longa e curta metragem, firmados pelos produtores com os distribuidores, sòmente terão validade depois de registrados no INC.

\section{CAPÍTULO $\mathrm{X}$}

Das Disposições Gerais

Art 36. São extintas a "taxa cinematográfica para educação popular" criada pelo art. 42 do Decreto-lei $n^{\circ} 1.949$, de 30 de dezembro de 1939, e o impôsto de importação e taxa de despacho aduaneiro sôbre filmes cinematográficos compreendidos nos itens 37-06, 37-07-00, 37-07-003, 37-07-004, 3707-005 e 37-07-006, da Tarifa das Alfândegas.

Parágrafo único. É concedida isenção do impôsto de importação e da taxa de despacho aduaneiro, às películas sensibilizadas, filmes virgens compreendidos nos itens 37-02-001, 37-02-003 e 3702.004 da Tarifa das Alfândegas, ficando o Poder Executivo autorizado a suspender os benefícios da isenção, quando fôr necessário estimular a produção nacional daqueles produtos.

Art 37. A censura de filmes cinematográficos, para todo o território nacional, tanto para exibição em cinemas, como para exibição em televisão, é da exclusiva competência da União.

Art 38. As remessas de filmes brasileiros para o exterior ficam sujeitas a "licença de exportação", sem cobertura cambial, devendo ser transferido para o Brasil o produto da venda, aluguel, participação e tôda a receita líquida assim auferida no exterior.

Parágrafo único. A receita acima aludida será transferida para o país obrigatòriamente através de estabelecimento bancário autorizado a operar um câmbio, observadas as normas e critérios que regerem a espécie à data de cada operação.

Art 39. A que se refere 0 art. 45, da Lei $n^{\circ} 4.131$, de 3 de setembro de 1962, deverá ser obrigatòriamente, recolhido ao Banco do Brasil S.A., em conta especial, podendo o interessado aplicar essa importância, mediante autorização do INC, na produção de filmes brasileiros.

$\S 1^{\circ}$ Se no prazo de 18 (dezoito) meses, contados da data de cada depósito, não fôr apresentado ao INC o projeto para a realização do filme, acompanhado da documentação indisponível ao exame do mesmo, o valor registrado no Banco do Brasil S.A., reverterá como receita extraordinária do INC. 
$\S 2^{\circ}$ Os titulares dos depósitos atualmente existentes no Banco do Brasil S.A., efetuados de acôrdo com o art. 45, da Lei $n^{\circ} 4.131$, de 3 de setembro de 1962, terão prazo máximo de 6 (seis) meses, a contar da publicação da presente Lei, para apresentação de seus projetos ao INC findo o qual, os depósitos reverterão ao Instituto.

Art 40. Os pagamentos no exterior de filmes adquiridos a preço fixo para exploração no País, ficarão igualmente sujeitos ao desconto do impôsto, nos têrmos do art. 45 , da Lei $n^{\circ} 4.131$, de 3 de setembro de 1962, o art. 28 da presente Lei.

Art 41. Os depósitos a que se referem os arts. 39 e 40 serão realizados pelo distribuidor ou importador do filme estrangeiro, em nome da emprêsa no Brasil, como beneficiária do favor fiscal.

Art 42. São incorporados ao INC o Instituto Nacional de Cinema Educativo, do Ministério da Educação e Cultura e o Grupo Executivo da Indústria Cinematográfica, do Ministério da Indústria e do Comércio.

Parágrafo único. O pessoal lotado, na data da publicação dêste Decreto, nos órgãos mencionados no presente artigo, passa a disposição do INC, sem prejuízo dos seus vencimentos, direitos e vantagens, obedecendo o disposto no art. 18 e seus parágrafos, do Decreto-Lei $n^{\circ} 43$, de 18 de novembro de 1966.

Art 43. As atribuições conferidas ao INC pelo referido Decreto-Lei poderão ser exercidas por autoridades estaduais e municipais, ou outras entidades públicas, mediante convênio.

Art 44. Para os efeitos dêste Decreto, produtores, distribuidores e exibidores de filmes só poderão exercer atividades no País depois de registrados no INC.

Parágrafo único. Os exibidores deverão registrar todos os cinemas de sua propriedade ou arrendados.

Art 45. É assegurado ao INC, por intermédio de seus funcionários especialmente designados, o direito de examinar a escrita comercial de produtores, distribuidores e exibidores, para verificar a exatidão das receitas atribuídas a cada uma das partes, quando se tratar de filmes nacionais.

Parágrafo único. É assegurado aos funcionários do INC, especialmente designados, o livre ingresso nos cinemas, em todo o território nacional, na forma estabelecida pelo Conselho Deliberativo.

Art 46. O INC poderá estabelecer a obrigatoriedade de uso de " borderaux " padrão, emitir, para uso compulsório pelas salas exibidoras nacionais, ingresso único ou obrigar o uso de máquinas registradoras, para venda de ingressos.

Parágrafo único. Para facilitar a fiscalização do uso do ingresso único, o INC poderá criar prêmio periódico entre os usuários dos cinemas, na forma que vier a ser estabelecida por Decreto do Executivo.

Art 47. Fica sujeito à multa que variará de um têrço (1/3) do valor do salário-mínimo, vigente no Distrito Federal à época da infração, até cem (100) vêzes o valor dêsse salário, sem prejuízo de outras sanções que couberem, àquele que:

I - Deixar de cumprir as normas legais sôbre a exibição de filmes nacionais;

II - Exibir filme ou " filmlet " de publicidade em desacôrdo com as normas legais;

III - Exibir filme não censurado ou com o certificado de censura fora dos prazos estabelecidos;

IV - Deixar de levar os programas a aprovação da autoridade competente ou exibi-los de maneira diversa do aprovado;

V - Sonegar ou prestar informação errônea, visando obter vantagens pecuniárias, ou ilidir pagamento de taxa ou contribuição devida, sem prejuízo da sanção penal que couber;

VI - Deixar de cumprir as normas que forem baixadas sôbre co-produção;

VII - Deixar de fornecer os " borderaux " nos prazos ou modelos que forem estabelecidos, bem como nêles incluir informação inverídica;

VIII - Reter o exibidor ou o distribuidor importância devida ao produtor, além dos prazos estabelecidos, ou pagá-la em valor inferior ao estabelecido na Lei;

IX - Utilizar ou permitir a utilização de ingresso fora do modelo padrão;

$X$ - Difilcutar ou impedir a observância das resoluções que forem baixadas em decorrência dêste Regulamento;

XI - Sonegar documentos ou comprovantes exigidos pelo INC ou impedir ou difilcutar exames contábeis ou deixar de fornecer esclarecimentos que forem exigidos, nos prazos assinados; 
XII - Vedar ou dificultar a entrada, nas salas exibidoras, de funcionários a serviço do INC.

Art 48. Em caso de reincidência, dentro do período de três (3) meses em infração da mesma natureza, o INC poderá determinar a interdição do estabelecimento por um prazo de cinco (5) a noventa (90) dias, sem prejuízo da multa que couber.

Art 49. A imposição, autuação e processamento da multa e sua cobrança, os prazos e condições para os recursos e normas de interdição dos estabelecimentos serão fixados pelo Conselho Deliberativo.

Art 50. O Conselho Deliberativo poderá baixar normas regimentais complementares a êste Regulamento.

Brasília, em 15 de fevereiro de 1967.

RAYMUNDO MONIZ DE ARAGÃO 


\title{
ANEXO III - REGULAMENTA A EMBRAFILME, EXTINGÜE O INC E CRIA O CONCINE ${ }^{145}$ \\ DECRETO No 78.108, DE 22 DE JULHO DE 1976
}

Aprova o novo Estatuto da Empresa Brasileira de Filmes Sociedade Anônima - EMBRAFILME, dá outras providências.

O PRESIDENTE DA REPÚBLICA, tendo em vista o disposto no artigo 17, da Lei $n^{\circ} 6.281$, de 9 de dezembro de 1975, e usando das atribuições que lhe confere o artigo 81, item III da Constituição, DECRETA:

Art $1^{\circ}$ Ficam aprovados o Estatuto Social da Empresa Brasileira de Filmes S.A. - EMBRAFILME, assinado pelo Ministro de Estado da Educação e Cultura, e a discriminação e caracterização do bem imóvel do extinto Instituto Nacional do Cinema - INC, transferido á EMBRAFILME, pela Lei $n^{\circ} 6.281$ de 9 de dezembro de 1975, que constituem anexos do presente Decreto.

Art $2^{\circ} \mathrm{A}$ identificação do imóvel referida no artigo anterior, servirá de título para a transcrição no registro de imóveis, conforme disposto no artigo 17, da Lei no 6.281, de 9 de dezembro de 1975.

Art $3^{\circ}$ Este Decreto entrará em vigor na data de sua publicação, revogadas as disposições em contrário.

Brasília, 22 de julho de 1976; $155^{\circ}$ da Independência e $88^{\circ}$ da República.

\section{ERNESTO GEISEL}

Ney Braga

\author{
EMPRESA BRASILEIRA DE FILMES S.A. - EMBRAFILME \\ ESTATUTO SOCIAL \\ CAPÍTULO I \\ Denominação, Natureza, Sede, Duração, Objeto
}

Art $1^{\circ}$ A Empresa Brasileira de Filmes S.A. - EMBRAFILME, criada de acordo com o Decreto-lei número 862, de 12 de setembro de 1969, com as alterações decorrentes da Lei $n^{\circ} 6.281$, de 9 de dezembro de 1975, é uma sociedade por ações de economia mista, dotada de personalidade jurídica de direito privado, vinculada ao Ministério da Educação e Cultura, regida pelo presente estatuto e pela legislação que lhe for pertinente.

Art $2^{\circ} \mathrm{A}$ sociedade tem sede e foro na Cidade do Rio de Janeiro, Estado do Rio de Janeiro, podendo instalar dependências e filiais no Brasil e no exterior, onde for conveniente à consecução de seu objeto social, a critério da assembléia geral.

Art $3^{\circ} \mathrm{O}$ prazo de duração da sociedade é indeterminado.

Art $4^{\circ}$ A sociedade tem por finalidade o desenvolvimento do cinema nacional, observados os princípios de liberdade de criação artística e respeito às manifestações culturais do povo brasileiro, competindo-lhe, dentre outras o exercício das seguintes atividades:

I - co-produção, aquisição, exportação e importação de filmes;

II - financiamento à indústria cinematográfica;

III - distribuição, exibição e comercialização de filmes no território nacional e no exterior;

IV - promoção e realização de festivais e mostras cinematográficas;

$\checkmark$ - seleção de filmes e organização de representações para participar em eventos cinematográficos internacionais de relevância cultural ou comercial;

$\mathrm{VI}$ - criação, quando convier, de subsidiárias para atuarem em qualquer dos campos de atividades cinematográficas;

${ }^{145}$ Extraído do site da Ancine 
VII - concessão de prêmios e incentivos a filmes nacionais, dentre estes o calculado proporcionalmente à renda produzida por sua exibição no País, de acordo com o que dispuser o Conselho Nacional de Cinema;

VIII - registro de produtores, distribuidores, exibidores, laboratórios e estúdios cinematográficos, observadas as normas estabelecidas pelo Conselho Nacional de Cinema;

IX - aprovação de projetos de instalação, ampliação e renovação de estúdios e laboratórios cinematográficos, para os efeitos de obtenção de quaisquer benefícios fiscais;

$X$ - venda e controle do uso de ingresso e borderôs padronizados pelas salas exibidoras.

Art $5^{\circ}$ Além do disposto no artigo anterior, a sociedade desempenhará, no campo da cultura cinematográfica, as seguintes atividades:

I - pesquisa, prospecção, recuperação e conservação de filmes;

II - produção, co-produção e difusão de filmes educativos, científicos, técnicos e culturais;

III - formação profissional;

IV - documentação e publicação;

$\mathrm{V}$ - promoções culturais cinematográficas.

Art $6^{\circ} \mathrm{A}$ Diretoria destinará anualmente um percentual dos recursos da sociedade para desenvolver as atividades previstas no artigo anterior, as quais, sempre que possível, serão executadas mediante convênio com escolas de cinema, cinematecas, cine clubes e outras entidades culturais sem fins lucrativos.

Art $7^{\circ}$ A sociedade poderá ainda exercer quaisquer outras atividades culturais, comerciais, e industriais relacionadas com seu objeto social bem como quaisquer atribuições que competiam ao Instituto Nacional do Cinema não abrangidas na área de atuação do Conselho Nacional do Cinema CONCINE.

\section{CAPÍTULO II}

Capital Social e Ações

Art $8^{\circ}$ O Capital da Sociedade é de $\mathrm{Cr} \$ 80.000 .000,00$ (oitenta milhões de cruzeiros), divididos em 8.000 .000 (oito milhões) de ações ordinárias nominativas, no valor de $\mathrm{Cr} \$ 10,00$ (dez cruzeiros) por ações, sendo $\mathrm{Cr} \$ 6.000 .000 .00$ (seis milhões de cruzeiros) já integralmente realizados.

Parágrafo único. A integralização pela União da sua restante participação no capital social far-se-á pela incorporação dos bens do extinto Instituto Nacional do Cinema complementada por dotações orçamentárias ou crédito especial, conforme previsto na Lei nº.281, de 9 de dezembro de 1975.

Art $9^{\circ}$ Cada ação dá direito a um voto nas deliberações das assembléias gerais da sociedade

Art 10. A União, resguardada a propriedade da maioria das ações com direito a voto, poderá transferir ações a entidades de direito público ou privado, bem como a pessoas físicas, desde que brasileiras, no sentido de integrar na empresa os realizadores cinematográficos dos país buscando ainda, sempre que possível, associar-se aos mesmos, visando inclusive amparar a iniciativa privada neste setor.

\section{CAPÍTULO III}

Fontes de Receita

Art 11. A receita da EMBRAFILME será constituída por:

I - dotações orçamentárias que Ihe forem consignadas pela União;

II - contribuição para o desenvolvimento da indústria cinematográfica nacional, devida pelos produtores ou distribuidores, na forma dos artigos $9^{\circ}$ e 11, da Lei $n^{\circ} 6.281$, de 9 de dezembro de 1975;

III - produto de operações de crédito;

IV - empréstimos, auxílios, subvenções, contribuições e doações de fontes internas e externas;

$\mathrm{V}$ - produto de multas;

VI - produto da venda de ingressos de borderôs padronizados;

VII - produto da comercialização e exibição de filmes e venda de bens patrimoniais;

VIII - juros e taxas de serviços provenientes de financiamentos; 
IX - fundo decorrente dos depósitos a que se refere o artigo 45, da Lei $n^{\circ} 4.131$, de 3 de setembro de 1962, com a redação dada pelo artigo $9^{\circ}$, do Decreto-lei no 862, de 12 de setembro de 1969;

$\mathrm{X}$ - rendas eventuais.

\section{CAPÍTULO IV \\ Assembléia Geral}

Art 12. A assembléia geral reunir-se-á ordinariamente até o dia 30 de abril de cada ano, para examinar, discutir e deliberar acerca do relatório da Diretoria, balanço, conta de lucros e perdas e parecer do Conselho Fiscal.

Art 13. A assembléia geral reunir-se-á extraordinariamente sempre que necessário ao interesse da sociedade.

Art 14. As assembléias gerais serão convocadas e instaladas pelo Diretor-Geral e presididas pelo representante da União, que convidará um acionista para secretário.

Parágrafo único. O Ministério da Educação e Cultura designará o representante da União nas Assembléias Gerais.

\section{CAPÍTULO V}

Diretoria

Art 15. A sociedade será administrada por uma Diretoria composta de 3 Diretores: o Diretor-Geral, nomeado pelo Presidente da República, com mandato de 4 anos, podendo ser reconduzido, o Diretor Administrativo e o Diretor de Operações Não Comerciais, estes com mandato de 2 anos, eleitos para assembléia geral, admitida a reeleição.

Art 16. As decisões da Diretoria serão tomadas por maioria de votos.

Art 17. Os Diretores serão empossados mediante lavratura de termo em livro próprio, permanecendo no exercício do cargo, findo o prazo do mandato, até a posse dos novos Diretores eleitos.

Art 18. Dentro de 30 (trinta) dias da posse, cada Diretor apresentará relação de seus bens e caucionará, em garantia da responsabilidade de sua gestão, 100 (cem), ações da sociedade próprios ou de terceiros, as quais serão liberadas após terem sido aprovados os atos e contas relativas ao último exercício de seu período de mandato.

Art 19. Os honorários e vantagens dos Diretores serão fixados pela assembléia geral.

Parágrafo único. O eventual exercício cumulativo pelos Diretores de mandato em subsidiárias não poderá importar em qualquer remuneração adicional.

Art 20. Os Diretores não poderão ausentar-se do País sem autorização do Ministro de Estado da Educação e Cultura.

Art 21. Nas hipóteses de vacância do cargo de Diretor, ressalvado o do Diretor-Geral, antes do término do respectivo mandato, a substituição se fará por indicação do Ministro de Estado da Educação e Cultura, até a assembléia geral seguinte quando se elegerá novo Diretor, iniciando novo mandato.

Art 22. O Diretor-Geral, em seus impedimentos eventuais, será substituído pelo Diretor Administrativo, e este pelo Diretor de Operações Não Comerciais, os quais, por sua vez, se substituirão reciprocamente.

Art 23. A Diretoria, nos limites da lei, fica investida de todos os poderes necessários à realização do objeto social, compreendidos os de contrair obrigações, transigir e renunciar direitos.

Art 24. A Diretoria incumbe:

I - estabelecer as diretorias e normas gerais da organização, administração e controle da sociedade e de suas eventuais subsidiárias, observada a política do desenvolvimento do cinema brasileiro 
formulada pelo Ministro de Estado da Educação e Cultura e orientação normativa baixada pelo Conselho Nacional de Cinema - CONCINE;

II - fixar o plano básico da organização da sociedade, que conterá a estruturação geral e definirá a natureza e as atribuições de cada órgão de execução, e as relações de subordinação, coordenação e controle necessários à melhor consecução do objeto social;

III - fixar critérios de análise e controle e aprovar projetos de realizações fílmicas através de aquisição, produção, co-produção, financiamento, adiantamento sobre receita de comercialização, e outras modalidades negociais, atinentes ao objeto social;

IV - aprovar planos e projetos de proteção, estimulo e desenvolvimento das atividades culturais cinematográficas;

V - deliberar acerca de participações acionárias e constituição de subsidiárias, submetendo a decisão à assembléia geral;

$\mathrm{VI}$ - aprovar projetos de instalação, ampliação e conservação de estúdios e laboratórios, para os efeitos de obtenção de quaisquer benefícios fiscais;

VII - decidir sobre a criação e concessão de prêmios e incentivos a produtores, autores, equipes técnicas e artísticas, bem como às demais atividades cinematográficas;

VIII - aprovar, em cada exercício, o balanço geral da sociedade, a demonstração da conta de lucros e perdas, e proposta de distribuição de dividendos e aplicação do saldo disponível, submetendo-os ao exame do Conselho Fiscal e à deliberação da assembléia geral;

IX - aprovar o orçamento anual da sociedade;

$X$ - decidir sobre qualquer outra matéria que the seja submetida por qualquer Diretor, relacionada com suas atribuições específicas ou atinente ao objeto social.

Art 25. Ao Diretor-Geral compete:

I - representar a sociedade, ativa e passivamente, em juízo e fora dele;

II - nomear procuradores, especificados no instrumento do mandato o objeto, limites e prazo da representação, conforme aprovado pela Diretoria;

III - autorizar despesas, e, juntamente com o Diretor Administrativo, assinar cheques e demais títulos de crédito;

IV - admitir, promover, licenciar, punir e dispensar empregados, observada a legislação pertinente;

$\mathrm{V}$ - firmar contratos, acordos, convênios e quaisquer atos que obriguem ou desonerem a sociedade perante terceiros, inclusive renúncia de direitos, observada a deliberação da Diretoria a respeito, bem como quaisquer outros atos cuja representação não tenha sido especialmente atribuída a qualquer dos demais Diretores;

$\mathrm{VI}$ - dirigir as operações sociais de produção, co-produção, financiamento, adiantamento sobre receita de comercialização, exibição, aquisição, exportação e importação de filmes, financiamento à indústria, distribuição e comercialização de filmes, ????? integradamente à atuação dos demais Diretores e na conformidade das decisões da Diretoria;

VII - orientar e coordenar as operações atinentes ao comércio e indústria cinematográfica e assuntos diretamente a eles afetos;

VIII - convocar as assembléias gerais, ressalvados os demais casos de convocação legal;

IX - participar como membro nato do Conselho Nacional de Cinema - CONCINE;

$X$ - resolver acerca de casos omissos singulares, não afetos naturalmente, por sua relevância, à decisão da Diretoria.

Art 26. O Diretor-Geral poderá delegar a qualquer dos Diretores, na medida da necessidade da dinamização e simplificação da Gestão Social, qualquer das atribuições e poderes de sua competência.

Art 27. Ao Diretor Administrativo caberá a coordenação executiva, dentre outras das áreas financeiras, de pessoal, controle e fiscalização, informática, serviços gerais e material, bem como atribuições que venham a ser delegadas pelo Diretor-Geral.

$\S 1^{\circ}$ Competirá ao Diretor Administrativo firmar chefes e demais títulos de crédito em conjunto com o Diretor-Geral, ou, por delegação deste com o Diretor de Operações Não Comerciais, ou, ainda, com procurador especialmente habilitado, nos limites fixados pela Diretoria.

$\S 2^{\circ}$ A assinatura de cheques poderá ser feita ainda em conjunto por dois procuradores expressamente constituídos e nos limites estabelecidos pela Diretoria.

Art 28. Ao Diretor de Operações Não Comerciais competirá atribuições atinentes a atuação da sociedade no campo da cultura cinematográfica, especialmente as referidas no artigo $5^{\circ}$ deste 
Estatuto, bem como a organização e participação em mostras e festivais no país e no exterior, seleção de filmes e representações em tais eventos, e ainda outras atribuições que venham a ser delegadas pelo Diretor-Geral.

\section{CAPÍTULO VI \\ Conselho Fiscal}

Art 29. A Sociedade terá um Conselho Fiscal, com as incumbências prevista em lei, composto de 3 (três) membros efetivos e igual número de suplentes, eleitos anualmente pela assembléia geral, que Ihes fixará os respectivos honorários, podendo ser reeleitos.

\section{CAPÍTULO VII \\ Exercício Social e Balanço}

Art 30. No fim de cada ano civil proceder-se-á o balanço geral, para verificação dos lucros e perdas. Art 31. Do lucro líquido apurado serão deduzidos 5\% (cinco por cento) para a constituição da reserva legal e até que esse fundo alcance $20 \%$ (vinte por cento) do capital social.

\section{CAPÍTULO VIII \\ Liquidação}

Art 32. A Sociedade entrará em regime de liquidação nos casos e na forma prevista em lei, revertendo seu acervo, após reembolsado o capital dos demais acionistas, ao patrimônio da União.

\section{CAPÍTULO IX}

Subsidiários e participações societárias

Art 33. A Sociedade, se conveniente ao seu objeto social, com a aprovação da assembléia geral, poderá criar subsidiárias ou participar do capital de outras sociedades.

Art 34. Na constituição de subsidiárias, a sociedade assegurará sempre o seu controle, restringido ainda a propriedade social a pessoas físicas ou jurídicas nacionais. 


\section{DECRETO No 77.299, DE 16 DE MARÇO DE 1976}

Cria, no Ministério da Educação e Cultura, o Conselho Nacional de Cinema - CONCINE - e dá outras providências.

O PRESIDENTE DA REPÚBLICA, no uso das atribuições que the confere o artigo 81, itens III e V, da Constituição, e tendo em vista o disposto no artigo $2^{\circ}$ da Lei $n^{\circ} 6.281$, de 9 de dezembro de 1975 , DECRETA:

Art $1^{\circ}$ Fica criado no Ministério da Educação e Cultura o Conselho Nacional de Cinema (CONCINE), diretamente subordinado ao Ministro de Estado, como órgão de orientação normativa e fiscalização das atividades relativas a cinema.

Art $2^{\circ}$ Compete ao CONCINE:

I - Assessorar o Ministro de Estado na formulação da política de desenvolvimento do cinema brasileiro;

II - Baixar normas reguladoras da importação e exportação de filmes, impressos ou gravados, para cinema, televisão e outro qualquer meio de veiculação;

III - Estabelecer condições de comercialização de filmes nacionais e estrangeiros, inclusive quanto a preços e prazos;

IV - Formular a política nacional de preços de ingressos de cinema, evitando tabelamentos que deteriorem as condições econômicas do cinema;

$\mathrm{V}$ - Regular a prestação de serviços de laboratórios e estúdios de som, locação de equipamentos e demais atividades concernentes à produção cinematográfica;

VI - Estabelecer normas de co-produção cinematográfica com outros países, em articulação com o Ministério das Relações Exteriores;

VII - Regular as condições de realização de produções cinematográficas estrangeiras no Brasil;

VIII - Regular a realização do país de filmes produzidos com recursos provenientes da exploração de filmes estrangeiros no território nacional;

IX - Estabelecer normas de registro de produtores, distribuidores, exibidores, laboratórios de som e imagem, importadores e exportadores de filmes e equipamentos cinematográficos;

X - Fixar o número de dias de exibição obrigatória de filmes nacionais de longa metragem, a participação percentual do produtor brasileiro na renda de bilheteria, e estabelecer a forma de cumprimento dessa exibição compulsória, por mês ou trimestre;

XI - Regular a reexibição do filme nacional no mesmo cinema para os efeitos da exibição compulsória, entendida reexibição como a programação do mesmo filme, transcorrido um determinado período de tempo de sua primeira exibição, no mesmo cinema;

XII - Regular a exibição compulsória de filme nacional exibido juntamente com filme estrangeiro;

XIII - Estabelecer normas para exibição obrigatória de filmes nacionais de curta metragem e jornais cinematográficos, inclusive regulando sua participação na receita de bilheteria;

XIV - Dispor sobre a forma de concessão pela EMBRAFILME de prêmio e incentivos a filmes nacionais, dentre este o calculado proporcionalmente à renda produzida por sua exibição no país;

XV - Estabelecer normas sobre o uso de "borderô padrão", emissão e venda para uso compulsório pelas salas exibidoras nacionais de ingressos padronizados e o uso de máquinas registradoras para venda de ingressos e roletas, ou outro qualquer sistema que vise a aprimorar a fiscalização dos cinemas;

XVI - Estabelecer normas sobre a projeção nos cinemas do país de mensagens publicitárias;

XVII - Estabelecer normas sobre a contribuição para o desenvolvimento da indústria cinematográfica nacional, devida pelos distribuidores ou produtores;

XVIII - Conceder o certificado de produto brasileiro ao filme assim considerado;

XIX - Estabelecer a definição de filme nacional de curta-metragem para os efeitos do artigo 13 da Lei $\mathrm{n}^{\circ}$ 6.281, de 9 de dezembro de 1975;

XX - Fazer o registro de que trata o artigo 17 da Lei n 5.988, de 14 de dezembro de 1973.

Parágrafo único. Das decisões do CONCINE caberá recurso para o Ministro da Educação e Cultura.

Art $3^{\circ}$ Compete ainda ao CONCINE fiscalizar em todo o território nacional o cumprimento das leis e regulamentos relativos às atividades cinematográficas, bem como aplicar multas e demais penalidades previstas na legislação. 
$\S 1^{\circ}$ É assegurado ao CONCINE, por intermédio de seus funcionários especialmente designados, o direito de examinar a escritura comercial de produtores, distribuidores, exibidores, para verificar a exatidão das receitas atribuídas a cada uma das partes, quando se tratar de filmes nacionais.

$\S 2^{\circ} \mathrm{O}$ CONCINE poderá estabelecer convênio com a Empresa Brasileira de Filmes S.A. EMBRAFILME, para realizar a fiscalização das atividades cinematográficas, atribuindo aos agentes de fiscalização indicados pela EMBRAFILME os poderes necessários à sua execução.

$\S 3^{\circ} \mathrm{E}$ assegurado aos funcionários do CONCINE, especialmente designados, o livre ingresso nos cinemas, em todo o território nacional, no exercício de suas funções.

Art $4^{\circ} \mathrm{O}$ Presidente do CONCINE será nomeado pelo Presidente da República por indicação do Ministro de Estado da Educação e Cultura.

Art $5^{\circ} \mathrm{O}$ CONCINE, além do Presidente, terá a seguinte composição:

I - Um representante da Secretaria de Planejamento da Presidência da República e de cada um dos seguintes Ministérios: Educação e Cultura, Justiça, Indústria e Comércio, Relações Exteriores, Fazenda e Comunicações, indicados pelos respectivos Ministros de Estado;

II - Diretor-Geral da Empresa Brasileira de Filmes S.A. - EMBRAFILME;

III - Diretor-Geral do Departamento de Assuntos Culturais do Ministério da Educação e Cultura;

IV - Três representantes de setores de atividades cinematográficas indicados pelo Ministro da Educação e Cultura, sendo um dos produtores, um de exibidores ou distribuidores e um de realizadores.

Parágrafo único. Os representantes e seus substitutos serão nomeados por ato do Presidente da República, com mandato de 2 (dois) anos, permitida a recondução por uma única vez.

Art $6^{\circ} \mathrm{O}$ Presidente do CONCINE, nos seus impedimentos, será substituído por um Conselheiro, designado pelo Ministro de Estado da Educação e Cultura.

Art $7^{\circ} \mathrm{O}$ Conselho, presente a maioria dos Conselheiros, reunir-se-á ordinariamente, uma vez por mês, e extraordinariamente sempre que o Presidente o convocar.

Art $8^{\circ}$ As deliberações do Conselho serão tomadas sob a forma de resoluções e por maioria de votos sendo o Presidente, além do voto próprio, o desempate.

Art $9^{\circ}$ O CONCINE disporá de uma Secretaria Executiva, com atribuições de suporte administrativo e assessoramento técnico.

Parágrafo único. A Secretaria Executiva será dirigida por um Secretário nomeado pelo Ministro da Educação e Cultura.

Art 10. O regime jurídico do pessoal do CONCINE será o da Consolidação das Leis do Trabalho.

Art 11. O CONCINE poderá celebrar contratos e convênios com entidades públicas e privadas, para realização de estudos, pesquisas e levantamentos relativos aos assuntos de sua competência.

Art 12. A organização e funcionamento do CONCINE serão definidos em Regimento Interno a ser baixado por Portaria do Ministro de Estado da Educação e Cultura.

Art 13. Este Decreto entrará em vigor na data de sua publicação, revogadas as disposições em contrário.

Brasília, 16 de março de 1976; $155^{\circ}$ da Independência e $88^{\circ}$ da República.

\author{
ERNESTO GEISEL \\ Armando Falcão \\ Antônio Francisco Azeredo da Silveira \\ Mário Henrique Simonsen \\ Ney Braga \\ Severo Fagundes Gomes \\ João Paulo dos Reis Velloso \\ Euclides Quandt de Oliveira
}


Cria mecanismos de fomento à atividade audiovisual e dá outras providências.

OPRESIDENTE DA REPÚBLICA Faço saber que o Congresso Nacional decreta e eu sanciono a seguinte Lei:

Art. $1^{\circ}$ Até o exercício fiscal de 2003, inclusive, os contribuintes poderão deduzir do imposto de renda devido as quantias referentes a investimentos feitos na produção de obras audiovisuais cinematográficas brasileiras de produção independente, conforme definido no art. $2^{\circ}$, incisos II e III, e no art. $3^{\circ}$, incisos I ell, da Lei $n^{\circ} 8.401$, de 8 de janeiro de 1992, mediante a aquisição de quotas representativas de direitos de comercialização sobre as referidas obras, desde que estes investimentos sejam realizados no mercado de capitais, em ativos previstos em lei e autorizados pela Comissão de Valores Mobiliários, e os projetos de produção tenham sido previamente aprovados pelo Ministério da Cultura. (Vide Lei $n^{\circ}$ 9.532, de 1997) (Vide Medida Provisória $n^{\circ} 2.228$, de 6.9.2001)

$\S 1^{\circ} \mathrm{A}$ responsabilidade dos adquirentes é limitada à integralização das quotas subscritas.

$\S 2^{\circ} \mathrm{A}$ dedução prevista neste artigo está limitada a três por cento do imposto devido pelas pessoas físicas e a um por cento do imposto devido pelas pessoas jurídicas. (Vide Lei 9.323, de 1996)

$\S 3^{\circ}$ Os valores aplicados nos investimentos de que trata o artigo anterior serão:

a) deduzidos do imposto devido no mês a que se referirem os investimentos, para as pessoas jurídicas que apuram o lucro mensal;

b) deduzidos do imposto devido na declaração de ajuste para:

1. as pessoas jurídicas que, tendo optado pelo recolhimento do imposto por estimativa, apuram o lucro real anual;

2. as pessoas físicas.

$\S 4^{\circ} \mathrm{A}$ pessoa jurídica tributada com base no lucro real poderá, também, abater o total dos investimentos efetuados na forma deste artigo como despesa operacional.

$\S 5^{\circ}$ Os projetos específicos da área audiovisual, cinematográfica de exibição, distribuição e infraestrutura técnica apresentados por empresa brasileira de capital nacional, poderão ser credenciados pelos Ministérios da Fazenda e da Cultura para fruição dos incentivos fiscais de que trata o caput deste artigo.

Art. $2^{\circ} \mathrm{O}$ art. 13 do Decreto-Lei $\mathrm{n}^{\circ} 1.089$, de 2 de março de 1970, altera do pelo art. $1^{\circ}$ do Decreto-Lei $n^{\circ}$ 1.741, de 27 de dezembro de 1979, passa a vigorar com a seguinte redação:

"Art. 13. As importâncias pagas, creditadas, empregadas, remetidas ou entregues aos produtores, distribuidores ou intermediários no exterior, como rendimentos decorrentes da exploração de obras audiovisuais estrangeiras em todo o território nacional, ou por sua aquisição ou importação a preço fixo, ficam sujeitas ao imposto de $25 \%$ na fonte."

\section{Art. 30 Vetado}

Art. $3^{\circ}$ Os contribuintes do Imposto de Renda incidente nos termos do art. 13 do Decreto-Lei $n^{0} 1.089$, de 1970 , alterado pelo art. $2^{\circ}$ desta Lei, poderão beneficiar-se de abatimento de $70 \%$ (setenta por cento) do imposto devido, desde que invistam no desenvolvimento de projetos de produção de obras cinematográficas brasileiras de longa metragem de produção independente, e naco-produção de telefilmes e minisséries brasileiros de produção independente e de obras cinematográficas brasileiras de produção independente. (Redação dada pela Lei no 10.454 , de 13.5.2002)

Art. $4^{\circ} \mathrm{O}$ contribuinte que optar pelo uso dos incentivos previstos nos arts. $1^{\circ}$ e $3^{\circ}$ depositará, dentro do prazo legal fixado para o recolhimento do imposto, o valor correspondente ao abatimento em conta de aplicação financeira especial, no Banco do Brasil S.A., cuja movimentação sujeitar-se-á à prévia comprovação junto ao Ministério da Cultura de que se destina a investimentos em projetos de produção de obras audiovisuais cinematográficas brasileiras de produção independente.

$\S 1^{\circ}$ As contas de aplicação financeira a que se refere este artigo serão abertas:

a) em nome do produtor, para cada projeto, no caso do art. $1^{\circ}$;

b) em nome do contribuinte, no caso do art. $3^{\circ}$.

${ }^{146}$ Extraído do site da Ancine http://www.ancine.gov.br/cgi/cgilua.exe/sys/start.htm?infoid=67\&sid=68 
\& $2^{\circ}$ Vetado

s. 10 Vetado

\& 20 Vetado

Art. 8Vetado

Art. 9 Vetado

Art. 10. Vetado

Art. 11. Vetado

Art. 12. Vetado

Art. 13. Vetado

Art. 14. Vetado

Art. 15. Fica revogado-ort. 45 da Lei no 4.131, de 3 de setembro de 1962.

Brasília, 20 de julho de 1993; $172^{\circ}$ da Independência e $105^{\circ}$ da República.

ITAMAR FRANCO

Fernando Henrique Cardoso

Antônio Houaiss

Este texto não substitui o publicado no D.O.U. de 21.7.1993 


\section{ANEXO V - LEI ROUANET ${ }^{147}$}

\section{LEI NN 8.313, DE 23 DE DEZEMBRO DE 1991}

Restabelece princípios da Lei $n^{\circ} 7.505$, de 2 de julho de 1986, institui o Programa Nacional de Apoio à Cultura

Texto Atualizado em 30.3.01

(Pronac) e dá outras providências.

Última Lei 9.999, 30.8.00

Última MP 2.189-49, de 23.8.01

O PRESIDENTE DA REPÚBLICA Faço saber que o Congresso Nacional decreta e eu sanciono a seguinte lei:

\section{CAPÍTULO I}

Disposições Preliminares

Art. $1^{\circ}$ Fica instituído o Programa Nacional de Apoio à Cultura (Pronac), com a finalidade de captar e canalizar recursos para o setor de modo a:

I - contribuir para facilitar, a todos, os meios para o livre acesso às fontes da cultura e o pleno exercício dos direitos culturais;

II - promover e estimular a regionalização da produção cultural e artística brasileira, com valorização de recursos humanos e conteúdos locais;

III - apoiar, valorizar e difundir o conjunto das manifestações culturais e seus respectivos criadores;

IV - proteger as expressões culturais dos grupos formadores da sociedade brasileira e responsáveis pelo pluralismo da cultura nacional;

V - salvaguardar a sobrevivência e o florescimento dos modos de criar, fazer e viver da sociedade brasileira;

$\mathrm{VI}$ - preservar os bens materiais e imateriais do patrimônio cultural e histórico brasileiro;

VII - desenvolver a consciência internacional e o respeito aos valores culturais de outros povos ou nações;

VIII - estimular a produção e difusão de bens culturais de valor universal, formadores e informadores de conhecimento, cultura e memória;

IX - priorizar o produto cultural originário do País.

Art. $2^{\circ} \mathrm{O}$ Pronac será implementado através dos seguintes mecanismos:

I - Fundo Nacional da Cultura (FNC);

II - Fundos de Investimento Cultural e Artístico (Ficart);

III - Incentivo a projetos culturais.

Parágrafo único. Os incentivos criados pela presente lei somente serão concedidos a projetos culturais que visem a exibição, utilização e circulação públicas dos bens culturais deles resultantes, vedada a concessão de incentivo a obras, produtos, eventos ou outros decorrentes, destinados ou circunscritos a circuitos privados ou a coleções particulares.

Art. $3^{\circ}$ Para cumprimento das finalidades expressas no art. $1^{\circ}$ desta lei, os projetos culturais em cujo favor serão captados e canalizados os recursos do Pronac atenderão, pelo menos, um dos seguintes objetivos:

I - incentivo à formação artística e cultural, mediante:

a) concessão de bolsas de estudo, pesquisa e trabalho, no Brasil ou no exterior, a autores, artistas e técnicos brasileiros ou estrangeiros residentes no Brasil;

b) concessão de prêmios a criadores, autores, artistas, técnicos e suas obras, filmes, espetáculos musicais e de artes cênicas em concursos e festivais realizados no Brasil;

c) instalação e manutenção de cursos de caráter cultural ou artístico, destinados à formação, especialização e aperfeiçoamento de pessoal da área da cultura, em estabelecimentos de ensino sem fins lucrativos;

II - fomento à produção cultural e artística, mediante:

a) produção de discos, vídeos, filmes e outras formas de reprodução fonovideográfica de caráter cultural; (Vide Medida Provisória $\mathrm{n}^{\circ}$ 2.228, de 6.9.2001)

b) edição de obras relativas às ciências humanas, às letras e às artes;

c) realização de exposições, festivais de arte, espetáculos de artes cênicas, de música e de folclore;

d) cobertura de despesas com transporte e seguro de objetos de valor cultural destinados a exposições públicas

no País e no exterior;

e) realização de exposições, festivais de arte e espetáculos de artes cênicas ou congêneres;

III - preservação e difusão do patrimônio artístico, cultural e histórico, mediante:

a) construção, formação, organização, manutenção, ampliação e equipamento de museus, bibliotecas, arquivos e outras organizações culturais, bem como de suas coleções e acervos;

b) conservação e restauração de prédios, monumentos, logradouros, sítios e demais espaços, inclusive naturais, tombados pelos Poderes Públicos;

${ }^{147}$ Extraído do site da Ancine http://www.ancine.gov.br/cgi/cgilua.exe/sys/start.htm?infoid=67\&sid=68 
c) restauração de obras de artes e bens móveis e imóveis de reconhecido valor cultural;

d) proteção do folclore, do artesanato e das tradições populares nacionais;

IV - estímulo ao conhecimento dos bens e valores culturais, mediante:

a) distribuição gratuita e pública de ingressos para espetáculos culturais e artísticos;

b) levantamentos, estudos e pesquisas na área da cultura e da arte e de seus vários segmentos;

c) fornecimento de recursos para o FNC e para fundações culturais com fins específicos ou para museus, bibliotecas, arquivos ou outras entidades de caráter cultural;

$\mathrm{V}$ - apoio a outras atividades culturais e artísticas, mediante:

a) realização de missões culturais no país e no exterior, inclusive através do fornecimento de passagens;

b) contratação de serviços para elaboração de projetos culturais;

c) ações não previstas nos incisos anteriores e consideradas relevantes pelo Ministro de Estado da Cultura, consultada a Comissão Nacional de Apoio à Cultura." (Redação dada pela Lei $\mathbf{n}^{\circ}$ 9.874, 23.11.99)

\section{CAPÍTULO II \\ Do Fundo Nacional da Cultura (FNC)}

Art. $4^{\circ}$ Fica ratificado o Fundo de Promoção Cultural, criado pela Lei $n^{\circ} 7.505$, de 2 de julho de 1986, que passará a denominar-se Fundo Nacional da Cultura (FNC), com o objetivo de captar e destinar recursos para projetos culturais compatíveis com as finalidades do Pronac e de:

I - estimular a distribuição regional eqüitativa dos recursos a serem aplicados na execução de projetos culturais e artísticos;

II - favorecer a visão interestadual, estimulando projetos que explorem propostas culturais conjuntas, de enfoque regional;

III - apoiar projetos dotados de conteúdo cultural que enfatizem o aperfeiçoamento profissional e artístico dos recursos humanos na área da cultura, a criatividade e a diversidade cultural brasileira;

IV - contribuir para a preservação e proteção do patrimônio cultural e histórico brasileiro;

$\mathrm{V}$ - favorecer projetos que atendam às necessidades da produção cultural e aos interesses da coletividade, aí considerados os níveis qualitativos e quantitativos de atendimentos às demandas culturais existentes, o caráter multiplicador dos projetos através de seus aspectos sócio-culturais e a priorização de projetos em áreas artísticas e culturais com menos possibilidade de desenvolvimento com recursos próprios.

$\S 1$ o O FNC será administrado pelo Ministério da Cultura e gerido por seu titular, para cumprimento do Programa de Trabalho Anual, segundo os princípios estabelecidos nos arts. 1 o e 3 o. (Redação dada pela Lei $\mathrm{n}^{\circ}$ 9.874, 23.11.99)

$\S 2$ o Os recursos do FNC somente serão aplicados em projetos culturais após aprovados, com parecer do órgão técnico competente, pelo Ministro de Estado da Cultura. (Redação dada pela Lei $\mathbf{n}^{\circ} \mathbf{9 . 8 7 4 , 2 3 . 1 1 . 9 9 )}$

$\S 3^{\circ}$ Os projetos aprovados serão acompanhados e avaliados tecnicamente pelas entidades supervisionadas, cabendo a execução financeira à SEC/PR.

$\S 4^{\circ}$ Sempre que necessário, as entidades supervisionadas utilizarão peritos para análise e parecer sobre os projetos, permitida a indenização de despesas com o deslocamento, quando houver, e respectivos pró-labore e ajuda de custos, conforme ficar definido no regulamento.

$\S 5^{\circ} \mathrm{O}$ Secretário da Cultura da Presidência da República designará a unidade da estrutura básica da SEC/PR que funcionará como secretaria executiva do FNC.

§ 6 o Os recursos do FNC não poderão ser utilizados para despesas de manutenção administrativa do Ministério da Cultura, exceto para a aquisição ou locação de equipamentos e bens necessários ao cumprimento das finalidades do Fundo. (Redação dada pela Lei $n^{\circ}$ 9.874, 23.11.99)

$\S 7^{\circ}$ Ao término do projeto, a SEC/PR efetuará uma avaliação final de forma a verificar a fiel aplicação dos recursos, observando as normas e procedimentos a serem definidos no regulamento desta lei, bem como a legislação em vigor.

$\S 8^{\circ}$ As instituições públicas ou privadas recebedoras de recursos do FNC e executoras de projetos culturais, cuja avaliação final não for aprovada pela SEC/PR, nos termos do parágrafo anterior, ficarão inabilitadas pelo prazo de três anos ao recebimento de novos recursos, ou enquanto a SEC/PR não proceder a reavaliação do parecer inicial.

Art. $5^{\circ} \mathrm{O}$ FNC é um fundo de natureza contábil, com prazo indeterminado de duração, que funcionará sob as formas de apoio a fundo perdido ou de empréstimos reembolsáveis, conforme estabelecer o regulamento, e constituído dos seguintes recursos:

I - recursos do Tesouro Nacional;

II - doações, nos termos da legislação vigente;

III - legados;

IV - subvenções e auxílios de entidades de qualquer natureza, inclusive de organismos internacionais;

$\checkmark$ - saldos não utilizados na execução dos projetos a que se referem o Capítulo IV e o presente capítulo desta lei; VI - devolução de recursos de projetos previstos no Capítulo IV e no presente capítulo desta lei, e não iniciados ou interrompidos, com ou sem justa causa;

VII - um por cento da arrecadação dos Fundos de Investimentos Regionais, a que se refere a Lei $n^{\circ} 8.167$, de 16 de janeiro de 1991, obedecida na aplicação a respectiva origem geográfica regional; 
VIII - Três por cento da arrecadação bruta dos concursos de prognósticos e loterias federais e similares cuja realização estiver sujeita a autorização federal, deduzindo-se este valor do montante destinados aos prêmios; (Redação dada pela Lei no 9.999, de 30.08.00)

IX - reembolso das operações de empréstimo realizadas através do fundo, a título de financiamento reembolsável, observados critérios de remuneração que, no mínimo, Ihes preserve o valor real;

$X$ - resultado das aplicações em títulos públicos federais, obedecida a legislação vigente sobre a matéria;

XI - conversão da dívida externa com entidades e órgãos estrangeiros, unicamente mediante doações, no limite a ser fixado pelo Ministro da Economia, Fazenda e Planejamento, observadas as normas e procedimentos do Banco Central do Brasil;

XII - saldos de exercícios anteriores; XIII recursos de outras fontes.

Art. $6^{\circ} \mathrm{O}$ FNC financiará até oitenta por cento do custo total de cada projeto, mediante comprovação, por parte do proponente, ainda que pessoa jurídica de direito público, da circunstância de dispor do montante remanescente ou estar habilitado à obtenção do respectivo financiamento, através de outra fonte devidamente identificada, exceto quanto aos recursos com destinação especificada na origem.

$\S 1^{\circ}$ (Vetado)

$\S 2^{\circ}$ Poderão ser considerados, para efeito de totalização do valor restante, bens e serviços oferecidos pelo proponente para implementação do projeto, a serem devidamente avaliados pela SEC/PR.

Art. $7^{\circ}$ A SEC/PR estimulará, através do FNC, a composição, por parte de instituições financeiras, de carteiras para financiamento de projetos culturais, que levem em conta o caráter social da iniciativa, mediante critérios, normas, garantias e taxas de juros especiais a serem aprovados pelo Banco Central do Brasil.

\section{CAPÍTULO III}

Dos Fundos de Investimento Cultural e Artístico (Ficart)

Art. $8^{\circ}$ Fica autorizada a constituição de Fundos de Investimento Cultural e Artístico (Ficart), sob a forma de condomínio, sem personalidade jurídica, caracterizando comunhão de recursos destinados à aplicação em projetos culturais e artísticos.

Art. 9 o São considerados projetos culturais e artísticos, para fins de aplicação de recursos do FICART, além de outros que venham a ser declarados pelo Ministério da Cultura: (Redação dada pela Lei $\mathbf{n}^{\circ} \mathbf{9 . 8 7 4 ,}$ 23.11.99)

I - a produção comercial de instrumentos musicais, bem como de discos, fitas, vídeos, filmes e outras formas de reprodução fonovideográficas:

II - a produção comercial de espetáculos teatrais, de dança, música, canto, circo e demais atividades congêneres;

III - a edição comercial de obras relativas às ciências, às letras e às artes, bem como de obras de referência e outras de cunho cultural;

IV - construção, restauração, reparação ou equipamento de salas e outros ambientes destinados a atividades com objetivos culturais, de propriedade de entidades com fins lucrativos;

$\mathrm{V}$ - outras atividades comerciais ou industriais, de interesse cultural, assim consideradas pelo Ministério da Cultura. (Redação dada pela Lei $n^{\circ}$ 9.874, 23.11.99)

Art. 10. Compete à Comissão de Valores Mobiliários, ouvida a SEC/PR, disciplinar a constituição, o funcionamento e a administração dos Ficart, observadas as disposições desta lei e as normas gerais aplicáveis aos fundos de investimento.

Art. 11. As quotas dos Ficart, emitidas sempre sob a forma nominativa ou escritural, constituem valores mobiliários sujeitos ao regime da Lei $n^{\circ}$ 6.385, de 7 de dezembro de 1976.

Art. 12. O titular das quotas de Ficart:

I - não poderá exercer qualquer direito real sobre os bens e direitos integrantes do patrimônio do fundo;

II - não responde pessoalmente por qualquer obrigação legal ou contratual, relativamente aos empreendimentos do fundo ou da instituição administradora, salvo quanto à obrigação de pagamento do valor integral das quotas subscritas.

Art. 13. A instituição administradora de Ficart compete:

I - representá-lo ativa e passivamente, judicial e extrajudicialmente;

II - responder pessoalmente pela evicção de direito, na eventualidade da liquidação deste.

Art. 14. Os rendimentos e ganhos de capital auferidos pelos Ficart ficam isentos do imposto sobre operações de crédito, câmbio e seguro, assim como do imposto sobre renda e proventos de qualquer natureza. (Revogada as isenções pela Lei $n^{\circ}$ 8.894, de 21/06/94)

Art. 15. Os rendimentos e ganhos de capital distribuídos pelos Ficart, sob qualquer forma, sujeitam-se à incidência do imposto sobre a renda na fonte à alíquota de vinte e cinco por cento. 
Parágrafo único. Ficam excluídos da incidência na fonte de que trata este artigo, os rendimentos distribuídos a beneficiário pessoas jurídica tributada com base no lucro real, os quais deverão ser computados na declaração anual de rendimentos.

Art. 16. Os ganhos de capital auferidos por pessoas físicas ou jurídicas não tributadas com base no lucro real, inclusive isentas, decorrentes da alienação ou resgate de quotas dos Ficart, sujeitam-se à incidência do imposto sobre a renda, à mesma alíquota prevista para a tributação de rendimentos obtidos na alienação ou resgate de quotas de fundos mútuos de ações.

$\S 1^{\circ}$ Considera-se ganho de capital a diferença positiva entre o valor de cessão ou resgate da quota e o custo médio atualizado da aplicação, observadas as datas de aplicação, resgate ou cessão, nos termos da legislação pertinente.

$\S 2^{\circ} \mathrm{O}$ ganho de capital será apurado em relação a cada resgate ou cessão, sendo permitida a compensação do prejuízo havido em uma operação com o lucro obtido em outra, da mesma ou diferente espécie, desde que de renda variável, dentro do mesmo exercício fiscal.

$\S 3^{\circ} \mathrm{O}$ imposto será pago até o último dia útil da primeira quinzena do mês subseqüente àquele em que o ganho de capital foi auferido.

$\S 4^{\circ}$ Os rendimentos e ganhos de capital a que se referem o caput deste artigo e o artigo anterior, quando auferidos por investidores residentes ou domiciliados no exterior, sujeitam-se à tributação pelo imposto sobre a renda, nos termos da legislação aplicável a esta classe de contribuintes.

Art. 17. O tratamento fiscal previsto nos artigos precedentes somente incide sobre os rendimentos decorrentes de aplicações em Ficart que atendam a todos os requisitos previstos na presente lei e na respectiva regulamentação a ser baixada pela Comissão de Valores Mobiliários.

Parágrafo único. Os rendimentos e ganhos de capital auferidos por Ficart, que deixem de atender aos requisitos específicos desse tipo de fundo, sujeitar-se-ão à tributação prevista no artigo 43 da Lei $n^{\circ} 7.713$, de 22 de dezembro de 1988.

\section{CAPÍTULO IV \\ Do Incentivo a Projetos Culturais}

Art. 18. Com o objetivo de incentivar as atividades culturais, a União facultará às pessoas físicas ou jurídicas a opção pela aplicação de parcelas do Imposto sobre a Renda, a título de doações ou patrocínios, tanto no apoio direto a projetos culturais apresentados por pessoas físicas ou por pessoas jurídicas de natureza cultural, como através de contribuições ao FNC, nos termos do art. 5 o, inciso II, desta Lei, desde que os projetos atendam aos critérios estabelecidos no art. 1 o desta Lei. (Redação dada pela Lei $\mathbf{n}^{\circ} \mathbf{9 . 8 7 4 , 2 3 . 1 1 . 9 9 )}$

$\S 1$ o Os contribuintes poderão deduzir do imposto de renda devido as quantias efetivamente despendidas nos projetos elencados no $\S 30$, previamente aprovados pelo Ministério da Cultura, nos limites e nas condições estabelecidos na legislação do imposto de renda vigente, na forma de: (Redação dada pela Lei $\mathbf{n}^{\circ} \mathbf{9 . 8 7 4}$, 23.11.99)

a) doações; e (Redação dada pela Lei $n^{\circ}$ 9.874, 23.11.99)

b) patrocínios. (Redação dada pela Lei $n^{\circ} 9.874,23.11 .99$ )

$\S 2$ o As pessoas jurídicas tributadas com base no lucro real não poderão deduzir o valor da doação ou do patrocínio referido no parágrafo anterior como despesa operacional. (Redação dada pela Lei $\mathbf{n}^{\circ} \mathbf{9 . 8 7 4}, \mathbf{2 3 . 1 1 . 9 9 )}$ § 3 o As doações e os patrocínios na produção cultural, a que se refere o $\S 1$ o, atenderão exclusivamente aos seguintes segmentos: (Redação dada pela Lei $\mathbf{n}^{\circ}$ 9.874, 23.11.99) (Vide Medida Provisória $n^{\circ} 2.228$, de $6.9 .2001)$

a) artes cênicas; (Redação dada pela Lei $\mathbf{n}^{\circ}$ 9.874, 23.11.99)

b) livros de valor artístico, literário ou humanístico; (Redação dada pela Lei $\mathbf{n}^{\circ} \mathbf{9 . 8 7 4 , 2 3 . 1 1 . 9 9 )}$

c) música erudita ou instrumental; (Redação dada pela Lei $\mathbf{n}^{\circ} 9.874,23.11 .99$ )

d) circulação de exposições de artes plásticas; (Redação dada pela Lei $\mathbf{n}^{\circ} \mathbf{9 . 8 7 4}, \mathbf{2 3 . 1 1 . 9 9}$ )

e) doações de acervos para bibliotecas públicas e para museus. (Redação dada pela Lei $\mathbf{n}^{\circ}$ 9.874, 23.11.99)

Art. 19. Os projetos culturais previstos nesta Lei serão apresentados ao Ministério da Cultura, ou a quem este delegar atribuição, acompanhados do orçamento analítico, para aprovação de seu enquadramento nos objetivos do PRONAC. (Redação dada pela Lei $n^{\circ}$ 9.874, 23.11.99)

$\S 1$ o O proponente será notificado dos motivos da decisão que não tenha aprovado o projeto, no prazo máximo de cinco dias. (Redação dada pela Lei $\mathbf{n}^{\circ}$ 9.874, 23.11.99)

§ 2 o Da notificação a que se refere o parágrafo anterior, caberá pedido de reconsideração ao Ministro de Estado da Cultura, a ser decidido no prazo de sessenta dias. (Redação dada pela Lei $\mathbf{n}^{\circ} \mathbf{9 . 8 7 4}, \mathbf{2 3 . 1 1 . 9 9 )}$

$\S 3^{\circ}$ (Vetado)

$\S 4^{\circ}$ (Vetado)

$\S 5^{\circ}$ (Vetado)

§ $6^{\circ} \mathrm{A}$ aprovação somente terá eficácia após publicação de ato oficial contendo o título do projeto aprovado e a instituição por ele responsável, o valor autorizado para obtenção de doação ou patrocínio e o prazo de validade da autorização. 
§ 7 o O Ministério da Cultura publicará anualmente, até 28 de fevereiro, o montante dos recursos autorizados pelo Ministério da Fazenda para a renúncia fiscal no exercício anterior, devidamente discriminados por beneficiário. (Redação dada pela Lei $\mathbf{n}^{\circ}$ 9.874, 23.11.99)

§ 8 o Para a aprovação dos projetos será observado o princípio da não-concentração por segmento e por beneficiário, a ser aferido pelo montante de recursos, pela quantidade de projetos, pela respectiva capacidade executiva e pela disponibilidade do valor absoluto anual de renúncia fiscal. (Redação dada pela Lei $\mathbf{n}^{\circ}$ 9.874, 23.11.99)

Art. 20. Os projetos aprovados na forma do artigo anterior serão, durante sua execução, acompanhados e avaliados pela SEC/PR ou por quem receber a delegação destas atribuições.

$\S 1^{\circ} \mathrm{A}$ SEC/PR, após o término da execução dos projetos previstos neste artigo, deverá, no prazo de seis meses, fazer uma avaliação final da aplicação correta dos recursos recebidos, podendo inabilitar seus responsáveis pelo prazo de até três anos.

§ 2 o Da decisão a que se refere o parágrafo anterior, caberá pedido de reconsideração ao Ministro de Estado da Cultura, a ser decidido no prazo de sessenta dias. (Redação dada pela Lei $\mathbf{n}^{\circ}$ 9.874, 23.11.99)

$\S 3^{\circ} \mathrm{O}$ Tribunal de Contas da União incluirá em seu parecer prévio sobre as contas do Presidente da República análise relativa a avaliação de que trata este artigo.

Art. 21. As entidades incentivadoras e captadoras de que trata este Capítulo deverão comunicar, na forma que venha a ser estipulada pelo Ministério da Economia, Fazenda e Planejamento, e SEC/PR, os aportes financeiros realizados e recebidos, bem como as entidades captadoras efetuar a comprovação de sua aplicação.

Art. 22. Os projetos enquadrados nos objetivos desta lei não poderão ser objeto de apreciação subjetiva quanto ao seu valor artístico ou cultural.

Art. 23. Para os fins desta lei, considera-se:

I - (Vetado)

II - patrocínio: a transferência de numerário, com finalidade promocional ou a cobertura, pelo contribuinte do imposto sobre a renda e proventos de qualquer natureza, de gastos, ou a utilização de bem móvel ou imóvel do seu patrimônio, sem a transferência de domínio, para a realização, por outra pessoa física ou jurídica de atividade cultural com ou sem finalidade lucrativa prevista no art. $3^{\circ}$ desta lei.

$\S 1$ o Constitui infração a esta Lei o recebimento pelo patrocinador, de qualquer vantagem financeira ou material em decorrência do patrocínio que efetuar.

§ 2 o As transferências definidas neste artigo não estão sujeitas ao recolhimento do Imposto sobre a Renda na fonte.

Art. 24. Para os fins deste Capítulo, equiparam-se a doações, nos termos do regulamento:

I - distribuições gratuitas de ingressos para eventos de caráter artístico-cultural por pessoa jurídica a seus empregados e dependentes legais;

II - despesas efetuadas por pessoas físicas ou jurídicas com o objetivo de conservar, preservar ou restaurar bens de sua propriedade ou sob sua posse legítima, tombados pelo Governo Federal, desde que atendidas as seguintes disposições:

a) preliminar definição, pelo Instituto Brasileiro do Patrimônio Cultural - IBPC, das normas e critérios técnicos que deverão reger os projetos e orçamentos de que trata este inciso;

b) aprovação prévia, pelo IBPC, dos projetos e respectivos orçamentos de execução das obras;

c) posterior certificação, pelo referido órgão, das despesas efetivamente realizadas e das circunstâncias de terem sido as obras executadas de acordo com os projetos aprovados.

Art. 25. Os projetos a serem apresentados por pessoas físicas ou pessoas jurídicas, de natureza cultural para fins de incentivo, objetivarão desenvolver as formas de expressão, os modos de criar e fazer, os processos de preservação e proteção do patrimônio cultural brasileiro, e os estudos e métodos de interpretação da realidade cultural, bem como contribuir para propiciar meios, à população em geral, que permitam o conhecimento dos bens de valores artísticos e culturais, compreendendo, entre outros, os seguintes segmentos:

I - teatro, dança, circo, ópera, mímica e congêneres;

II - produção cinematográfica, videográfica, fotográfica, discográfica e congêneres;

III - literatura, inclusive obras de referência;

IV - música;

V - artes plásticas, artes gráficas, gravuras, cartazes, filatelia e outras congêneres;

$\mathrm{VI}$ - folclore e artesanato;

VII - patrimônio cultural, inclusive histórico, arquitetônico, arqueológico, bibliotecas, museus, arquivos e demais acervos;

VIII - humanidades; e

IX - rádio e televisão, educativas e culturais, de caráter não-comercial.

Parágrafo único. Os projetos culturais relacionados com os segmentos do inciso II deste artigo deverão beneficiar exclusivamente as produções independentes, bem como as produções culturais-educativas de caráter não comercial, realizadas por empresas de rádio e televisão. (Redação dada pela Lei $\mathbf{n}^{\circ} \mathbf{9 . 8 7 4}, \mathbf{2 3 . 1 1 . 9 9 )}$ 
Art. 26. O doador ou patrocinador poderá deduzir do imposto devido na declaração do Imposto sobre a Renda os valores efetivamente contribuídos em favor de projetos culturais aprovados de acordo com os dispositivos desta Lei, tendo como base os seguintes percentuais: (vide art. $6^{\circ}$ inciso II da Lei $n^{\circ} 9.532$ de, 10.12.97 e MPV 2.189-49 de, 23.8.01)

I - no caso das pessoas físicas, oitenta por cento das doações e sessenta por cento dos patrocínios;

II - no caso das pessoas jurídicas tributadas com base no lucro real, quarenta por cento das doações e trinta por cento dos patrocínios.

§ 1 o A pessoa jurídica tributada com base no lucro real poderá abater as doações e patrocínios como despesa operacional.

§ 2 o O valor máximo das deduções de que trata o caput deste artigo será fixado anualmente pelo Presidente da República, com base em um percentual da renda tributável das pessoas físicas e do imposto devido por pessoas jurídicas tributadas com base no lucro real.

$\S 3$ o Os benefícios de que trata este artigo não excluem ou reduzem outros benefícios, abatimentos e deduções em vigor, em especial as doações a entidades de utilidade pública efetuadas por pessoas físicas ou jurídicas.

$\S 40$ (VETADO)

§ 5 o O Poder Executivo estabelecerá mecanismo de preservação do valor real das contribuições em favor de projetos culturais, relativamente a este Capítulo.

Art. 27. A doação ou o patrocínio não poderá ser efetuada a pessoa ou instituição vinculada ao agente.

$\S 1$ o Consideram-se vinculados ao doador ou patrocinador:

a) a pessoa jurídica da qual o doador ou patrocinador seja titular, administrador, gerente, acionista ou sócio, na data da operação, ou nos doze meses anteriores;

b) o cônjuge, os parentes até o terceiro grau, inclusive os afins, e os dependentes do doador ou patrocinador ou dos titulares, administradores, acionistas ou sócios de pessoa jurídica vinculada ao doador ou patrocinador, nos termos da alínea anterior;

c) outra pessoa jurídica da qual o doador ou patrocinador seja sócio.

§ 2 o Não se consideram vinculadas as instituições culturais sem fins lucrativos, criadas pelo doador ou patrocinador, desde que devidamente constituídas e em funcionamento, na forma da legislação em vigor. (Redação dada pela Lei $\mathbf{n}^{\circ}$ 9.874, 23.11.99)

Art. 28. Nenhuma aplicação dos recursos previstos nesta Lei poderá ser feita através de qualquer tipo de intermediação.

Parágrafo único. A contratação de serviços necessários à elaboração de projetos para a obtenção de doação, patrocínio ou investimento, bem como a captação de recursos ou a sua execução por pessoa jurídica de natureza cultural, não configura a intermediação referida neste artigo. (Redação dada pela Lei $\mathbf{n}^{\circ}$ 9.874, 23.11.99)

Art. 29. Os recursos provenientes de doações ou patrocínios deverão ser depositados e movimentados, em conta bancária específica, em nome do beneficiário, e a respectiva prestação de contas deverá ser feita nos termos do regulamento da presente Lei.

Parágrafo único. Não serão consideradas, para fins de comprovação do incentivo, as contribuições em relação às quais não se observe esta determinação.

Art. 30. As infrações aos dispositivos deste capítulo, sem prejuízo das sanções penais cabíveis, sujeitarão o doador ou patrocinador ao pagamento do valor atualizado do Imposto sobre a Renda devido em relação a cada exercício financeiro, além das penalidades e demais acréscimos previstos na legislação que rege a espécie.

$\S 1$ o Para os efeitos deste artigo, considera-se solidariamente responsável por inadimplência ou irregularidade verificada a pessoa física ou jurídica propositora do projeto. (Redação dada pela Lei $\mathbf{n}^{\circ} \mathbf{9 . 8 7 4 , 2 3 . 1 1 . 9 9 )}$

§ 2 o A existência de pendências ou irregularidades na execução de projetos da proponente junto ao Ministério da Cultura suspenderá a análise ou concessão de novos incentivos, até a efetiva regularização. (Redação dada pela Lei $n^{\circ} 9.874,23.11 .99$ )

$\S 3$ o Sem prejuízo do parágrafo anterior, aplica-se, no que couber, cumulativamente, o disposto nos arts. 38 e seguintes desta Lei. (Redação dada pela Lei $n^{\circ}$ 9.874, 23.11.99)

\section{CAPÍTULO V}

DAS DISPOSIÇÕES GERAIS E TRANSITÓRIAS

Art. 31. Com a finalidade de garantir a participação comunitária, a representação de artista e criadores no trato oficial dos assuntos da cultura e a organização nacional sistêmica da área, o Governo Federal estimulará a institucionalização de Conselhos de Cultura no Distrito Federal, nos Estados, e nos Municípios.

Art. 32. Fica instituída a Comissão Nacional de incentivo à Cultura - CNIC, com a seguinte composição:

I - o Secretário da Cultura da Presidência da República;

II - os Presidentes das entidades supervisionadas pela SEC/PR;

III - o Presidente da entidade nacional que congregar os Secretários de Cultura das Unidades Federadas;

IV - um representante do empresariado brasileiro;

$\mathrm{V}$ - seis representantes de entidades associativas dos setores culturais e artísticos de âmbito nacional. 
$\S 1$ o A CNIC será presidida pela autoridade referida no inciso I deste artigo que, para fins de desempate terá o voto de qualidade.

$\S 2$ o Os mandatos, a indicação e a escolha dos representantes a que se referem os incisos IV e $\vee$ deste artigo, assim como a competência da CNIC, serão estipulados e definidos pelo regulamento desta Lei.

Art. 33. A SEC/PR, com a finalidade de estimular e valorizar a arte e a cultura, estabelecerá um sistema de premiação anual que reconheça as contribuições mais significativas para a área:

I - de artistas ou grupos de artistas brasileiros ou residentes no Brasil, pelo conjunto de sua obra ou por obras individuais;

II - de profissionais da área do patrimônio cultural;

III - de estudiosos e autores na interpretação crítica da cultura nacional, através de ensaios, estudos e pesquisas.

Art. 34. Fica instituída a Ordem do Mérito Cultural, cujo estatuto será aprovado por Decreto do Poder Executivo, sendo que as distinções serão concedidas pelo Presidente da República, em ato solene, a pessoas que, por sua atuação profissional ou como incentivadoras das artes e da cultura, mereçam reconhecimento.

Art. 35. Os recursos destinados ao então Fundo de Promoção Cultural, nos termos do art. 1 o, § 6 o, da Lei n o 7.505, de 2 de julho de 1986, serão recolhidos ao Tesouro Nacional para aplicação pelo FNC, observada a sua finalidade.

Art. 36. O Departamento da Receita Federal, do Ministério da Economia, Fazenda e Planejamento, no exercício de suas atribuições específicas, fiscalizará a efetiva execução desta Lei, no que se refere à aplicação de incentivos fiscais nela previstos.

Art. 37. O Poder Executivo a fim de atender o disposto no art. 26, § 2 o, desta Lei, adequando-o às disposições da Lei de Diretrizes Orçamentárias, enviará, no prazo de 30 dias, Mensagem ao Congresso Nacional, estabelecendo o total da renúncia fiscal e correspondente cancelamento de despesas orçamentárias.

Art. 38. Na hipótese de dolo, fraude ou simulação, inclusive no caso de desvio de objeto, será aplicada, ao doador e ao beneficiário, multa correspondente a duas vezes o valor da vantagem recebida indevidamente.

Art. 39. Constitui crime, punível com a reclusão de dois a seis meses e multa de vinte por cento do valor do projeto, qualquer discriminação de natureza política que atente contra a liberdade de expressão, de atividade intelectual e artística, de consciência ou crença, no andamento dos projetos a que se refere esta Lei.

Art. 40. Constitui crime, punível com reclusão de dois a seis meses e multa de vinte por cento do valor do projeto, obter redução do imposto de renda utilizando-se fraudulentamente de qualquer benefício desta Lei.

$\S 1$ o No caso de pessoa jurídica respondem pelo crime o acionista controlador e os administradores que para ele tenham concorrido.

§ 2 o $\mathrm{Na}$ mesma pena incorre aquele que, recebendo recursos, bens ou valores em função desta Lei, deixa de promover, sem justa causa, atividade cultural objeto do incentivo.

Art. 41. O Poder Executivo, no prazo de sessenta dias, Regulamentará a presente lei.

Art. 42. Esta lei entra em vigor na data de sua publicação.

Art. 43. Revogam-se as disposições em contrário.

Brasília, 23 de dezembro de 1991; 170 da Independência e $103^{\circ}$ da República.

FERNANDO COLLOR

Jarbas Passarinho

Este texto não substitui o publicado no D.O.U. de 24.12.1991 